1aracterization of Water Quality and Simulation $4 / 3100$ Temperature, Nutrients, Biochemical Oxygen emand, and Dissolved Oxygen in the ateree River, South Carolina, 1996-98

Geological Survey

ter-Resources Investigations 99-4234 


\section{Characterization of Water Quality and}

Simulation of Temperature, Nutrients, Biochemical Oxygen Demand, and Dissolved Oxygen in the Wateree River, South Carolina, 1996-98

By Toby D. Feaster and Paul A. Conrads

U.S. GEOLOGICAL SURVEY

Water-Resources Investigations Report 99-4234

Columbia, South Carolina 2000

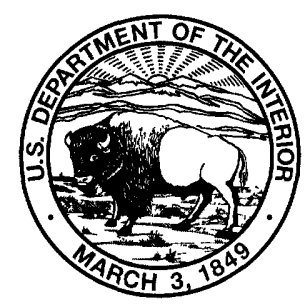




\section{ABBREVIATIONS AND ACRONYMS USED IN THIS REPORT:}

$\begin{array}{ll}\text { BLTM } & \text { Branched Lagrangian Transport Model } \\ \text { BOD } & \text { biochemical oxygen demand } \\ \text { BOD }_{5} & \text { 5-day biochemical oxygen demand } \\ \text { BOD }_{30} & \text { 30-day biochemical oxygen demand } \\ \text { CBOD }_{\mathrm{u}} & \text { ultimate carbonaceous biochemical oxygen demand } \\ \text { DCP } & \text { data collection platform } \\ \text { DO } & \text { dissolved oxygen } \\ \text { EST } & \text { Eastern Standard Time } \\ \text { FW } & \text { freshwater } \\ \text { KCWSA } & \text { Kershaw County Water and Sewer Authority } \\ \mu \text { g/L } & \text { microgram per liter } \\ \text { mg/L } & \text { milligram per liter } \\ \text { (mg/L)/g } & \text { milligram per liter per gram } \\ \text { NPDES } & \text { National Pollutant Discharge Elimination System } \\ \text { RM } & \text { river mile } \\ \text { SCDHEC } & \text { South Carolina Department of Health and Environmental Control } \\ \text { SOD } & \text { sediment oxygen demand } \\ \text { STORET } & \text { U.S. Environmental Protection Agency (STOrage and RETrieval) } \\ \text { TKN } & \text { water-quality data base } \\ \text { TMDL } & \text { total Kjeldahl nitrogen } \\ \text { TOC } & \text { total maximum daily load } \\ \text { UOD } & \text { total organic carbon } \\ \text { USEPA } & \text { ultimate oxygen demand } \\ \text { USGS } & \text { U.S. Environmental Protection Agency } \\ & \text { U.S. Geological Survey }\end{array}$

Cover photograph: Wateree River at the railroad trestle located downstream from the U.S. 1 bridge, Kershaw County, South Carolina. Photograph taken by Toby D. Feaster, U.S. Geological Survey. 


\section{U.S. DEPARTMENT OF THE INTERIOR \\ BRUCE BABBITT, Secretary}

U.S. GEOLOGICAL SURVEY

Charles G. Groat, Director

The use of firm, trade, and brand names in this report is for identification purposes

only and does not constitute endorsement by the U.S. Geological Survey.

For additional information write to:

Copies of this report can be purchased from:

District Chief

U.S. Geological Survey

720 Gracern Road, Suite 129

Columbia, SC 29210
U.S. Geological Survey Information Services Box 25286, Denver Federal Center Denver, CO 80225 


\section{CONTENTS}

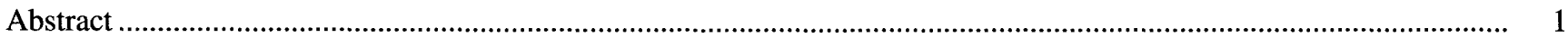

Introduction

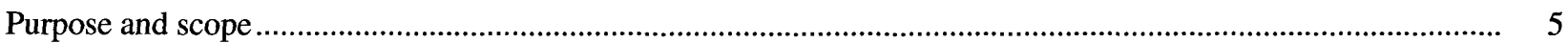

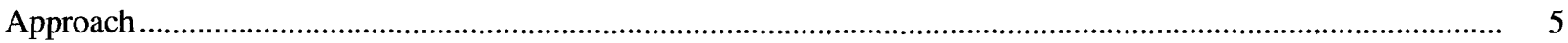

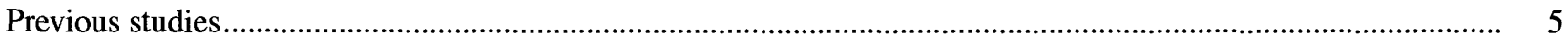

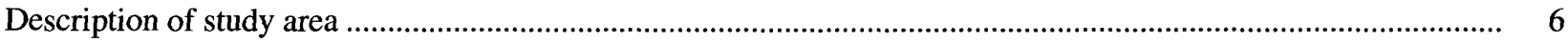

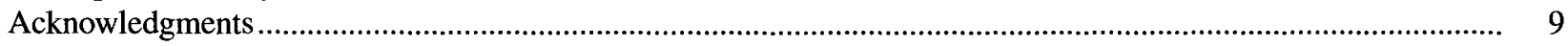

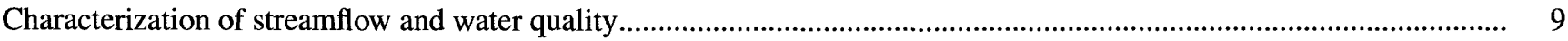

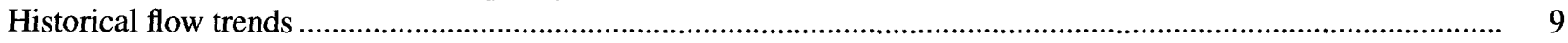

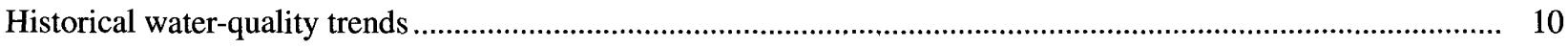

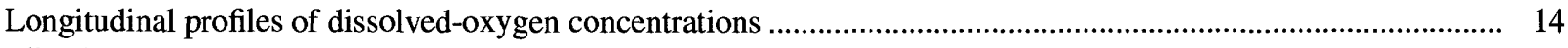

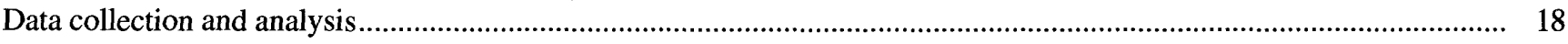

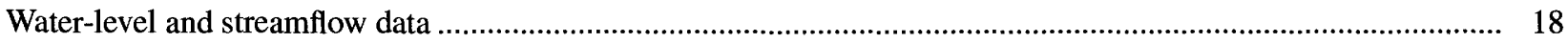

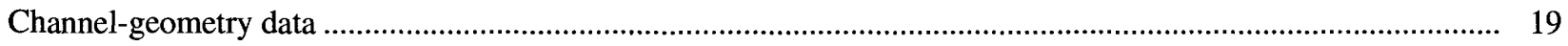

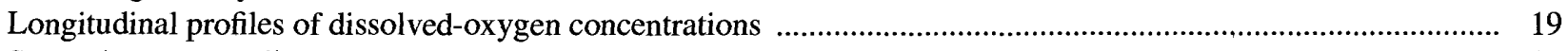

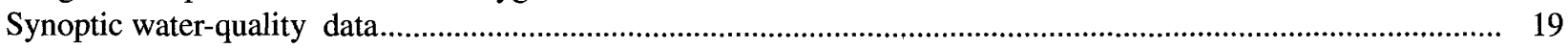

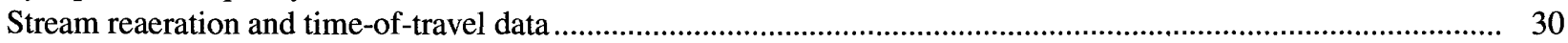

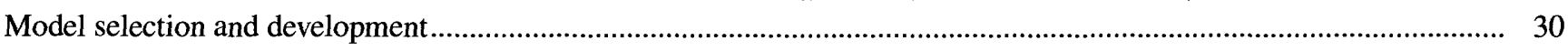

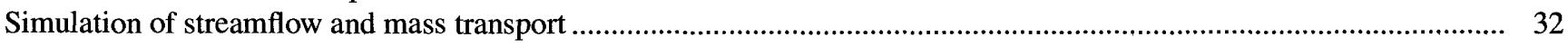

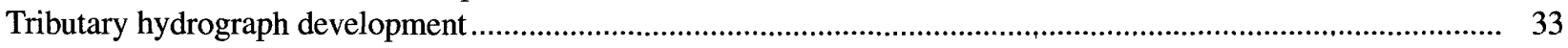

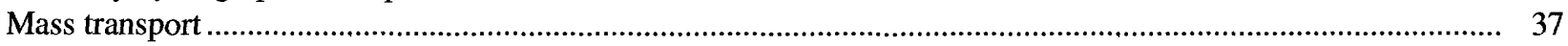

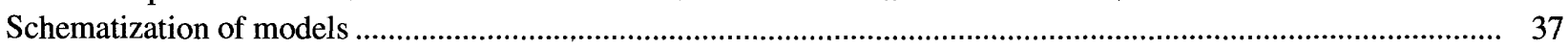

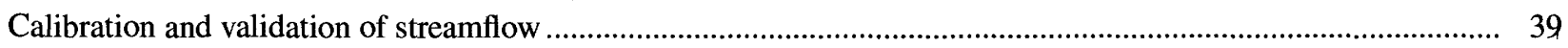

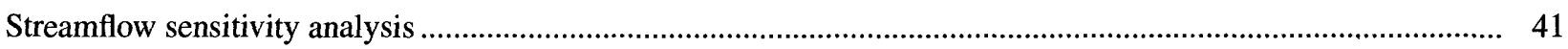

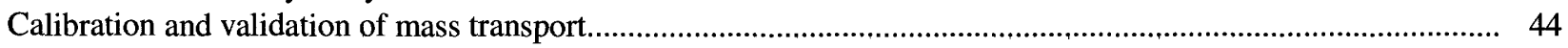

Simulation of temperature, nutrients, biochemical oxygen demand, and dissolved oxygen ....................................... 49

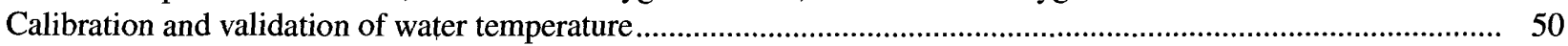

Calibration and validation of nutrients, biochemical oxygen demand, and dissolved oxygen ............................... 50

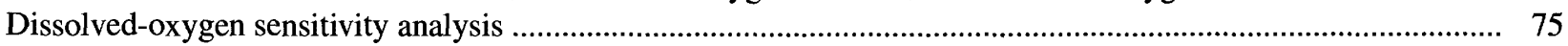

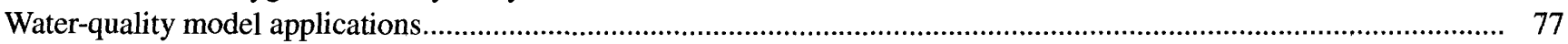

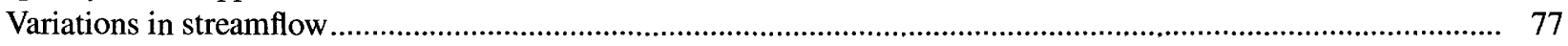

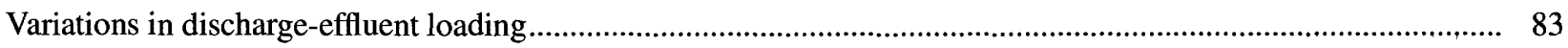

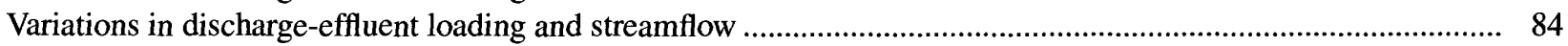

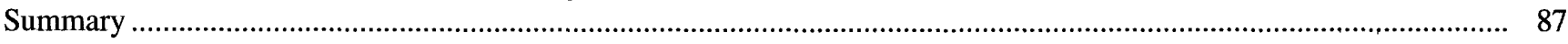

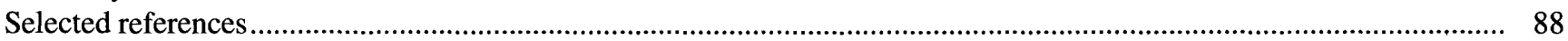

\section{FIGURES}

1-3. Maps showing:

1. The Catawba-Wateree River Basin, in North Carolina and South Carolina

2. Locations of the South Carolina Department of Health and Environmental Control water-quality monitoring stations and National Pollutant Discharge Elimination System effluent discharge sites included in the Branched Lagrangian Transport Model for the Wateree River, S.C.

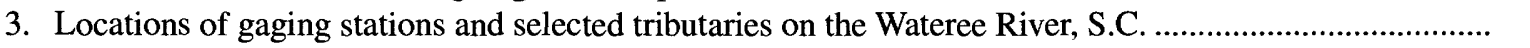

4-8. Graphs showing:

4. Minimum bed elevations at surveyed cross sections on the Wateree River, S.C., and U.S. Geological Survey topographic map contours that intersect the river 
5. Monthly daily-mean streamflow at USGS station 02148000 , Wateree River at Camden, S.C., 1929-97.

6. Comparison of median weekday and median weekend streamflow as a ratio of the water-year median 7-day weekly streamflow at USGS station 02148000 on the Wateree River, S.C.

7. Longitudinal profiles of dissolved-oxygen concentrations in the Wateree River, S.C., May-September 1996.

8. (A) Dissolved-oxygen concentrations, (B) water temperature, and (C) streamflow at three locations on the Wateree River, S.C., May 25-31, 1997.

9. Map showing river miles, in-river and tributary water-quality sampling sites, and National Pollutant Discharge Elimination System effluent discharge sites included in the Branched Lagrangian Transport Model for the Wateree River, S.C.

10-13. Graphs showing:

10. Three water parcels tracked from site 2 to site 12 based on travel time of peak dye concentrations, and water-quality sample collection times for the Wateree River, S.C., June 23-25 and August 11-13, 1997.

11. Measured dissolved-oxygen concentrations at 11 locations on the Wateree River, S.C., June 23-25 and August 11-13, 1997

12. Water-quality data collected at 11 locations on the Wateree River, S.C., June 23-25, 1997

13. Water-quality data collected at 11 locations on the Wateree River, S.C., August 11-13, 1997

14. Diagram showing idealized BRANCH model schematization

15. Graphs showing measured streamflow at USGS stations 02148000,02148306 , and 02148315 used to estimate tributary inflow for the calibration and validation simulations on the Wateree River, S.C., June 22-30 and August 10-18, 1997.

16. Graphs showing streamflow measured at five tributaries to the Wateree River, S.C., June 23-25, and August 11-13, 1997

17. Diagram showing (A) BRANCH model and (B) Branched Lagrangian Transport Model schematization for the Wateree River, S.C.

18. Map showing locations of branches and cross sections used in the Branched Lagrangian Transport Model for the Wateree River, S.C.

19-25. Graphs showing:

19. Simulated and measured streamflow used in the BRANCH model calibration for three locations on the Wateree River, S.C., June 22-30, 1997.

20. Simulated and measured streamflow used in the BRANCH model validation for three locations on the Wateree River, S.C., August 10-18, 1997

21. Sensitivity of simulated streamflow to changes in (A) flow-resistance coefficient, (B) downstream boundary gage datum, and (C) cross-sectional datum for USGS station 021480708 (site 9, river mile 52.5) on the Wateree River, S.C., June 22-30, 1997

22. Time-of-travel response curves for two locations on the Wateree River, S.C., June 24, 1997

23. Time-of-travel response curves for two locations on the Wateree River, S.C., August 11, 1997

24. Simulated and measured dye concentration calibration for six locations on the Wateree River, S.C., June 23-25, 1997.

25. Simulated and measured dye concentration validation for five locations on the Wateree River, S.C., August 11-13, 1997

26. Diagram showing major constituent interactions in the QUAL2E subroutine of the Branched Lagrangian Transport Model

27. Simulated and measured water temperatures used in the Branched Lagrangian Transport Model calibration for eight locations on the Wateree River, S.C., June 23-25, 1997

28. Simulated and measured water temperatures used in the Branched Lagrangian Transport Model validation for eight locations on the Wateree River, S.C., August 11-13, 1997

29-36. Graphs showing simulated and measured concentrations used in the Branched Lagrangian Transport Model calibration for eight locations on the Wateree River, S.C., June 23-25, 1997:

29. Dissolved oxygen

30. Organic nitrogen

31. Ammonia nitrogen

32. Nitrate nitrogen 


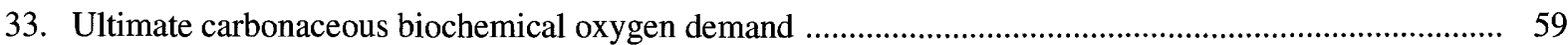

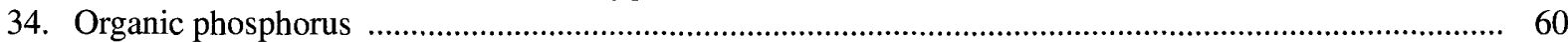

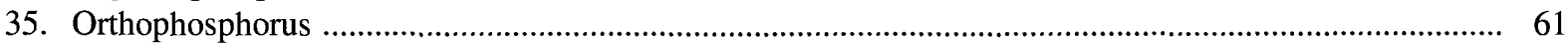

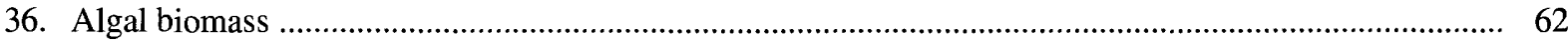

37-44. Graphs showing simulated and measured concentrations used in the Branched Lagrangian Transport

Model validation for eight locations on the Wateree River, S.C., August 11-13, 1997:

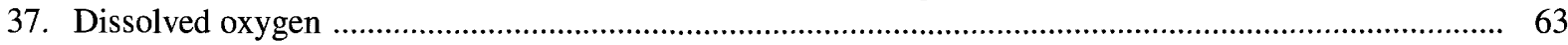

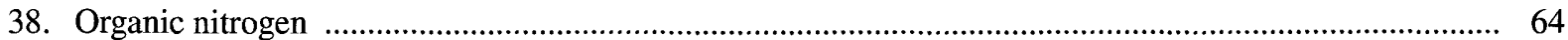

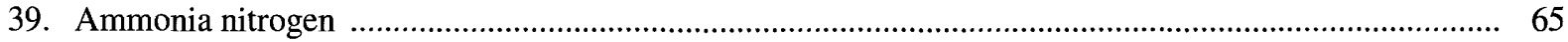

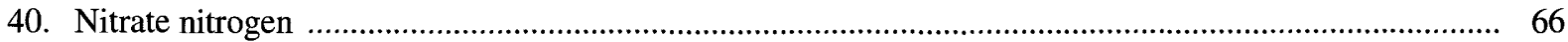

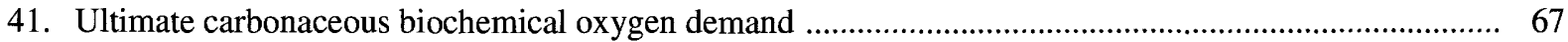

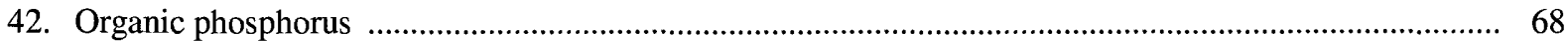

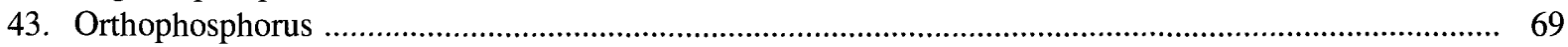

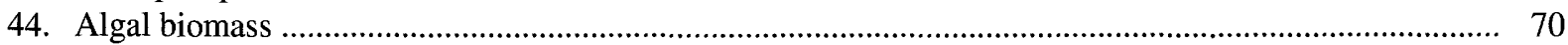

45-51. Graphs showing:

45. Boundary streamflow conditions at USGS station 02147930 that were used to compare the effects of changing flow patterns on the 24-hour mean dissolved-oxygen concentration from August 13, 1997,

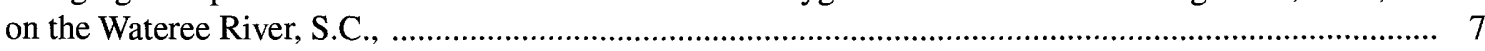

46. Longitudinal profiles of 24-hour mean dissolved-oxygen concentrations for three different streamflow periods on the Wateree River, S.C., using water-quality boundary data from August 13, 1997 ............... 78

47. Simulated dissolved-oxygen concentration budget at branch 1 grid 9 (river mile 57.4) on the Wateree River, S.C., for the August 9-14, 1997, flow period.

48. Simulated dissolved-oxygen concentration budget at branch 1 grid 9 (river mile 57.4) on the Wateree River, S.C., for the May 2-7, 1988, flow period...

49. Simulated dissolved-oxygen concentration budget at branch 1 grid 9 (river mile 57.4) on the Wateree River, S.C., for August 9-14, 1997, using the June 14-19, 1988, flow period.

50. Longitudinal profiles of 24-hour mean and minimum dissolved-oxygen concentration differences between the no-load condition and two point-source loading conditions at eight locations on the Wateree River, S.C., August 13, 1997.

51. Longitudinal profiles of 24-hour mean dissolved-oxygen concentrations for three streamflow periods assuming fully permitted effluent loads at eight locations on the Wateree River, S.C.

\section{TABLES}

1. Drainage areas of major tributaries to the Wateree River, S.C

2. South Carolina Department of Health and Environmental Control water-quality monitoring stations on Lake Wateree and the Wateree River, S.C .

3. Monthly daily-mean streamflow percentiles at USGS station 02148000, Wateree River at Camden, S.C., 1929-97

4. Summary of statistical trends in concentrations of water-quality constituents in Lake Wateree and the Wateree River, S.C

5. Stepwise regression analysis of daily-minimum and daily-mean dissolved oxygen, daily-mean water temperature, and daily-mean streamflow at USGS stations 02148000 and 02148315 on the Wateree River, S.C.

6. Average streamflow at USGS station 02148000, Wateree River at Camden, S.C., and beginning and ending sampling times during the longitudinal profiles of dissolved oxygen on the Wateree River, S.C.

Streamflow or water-level gaging stations and(or) water-quality monitoring stations on the Wateree River, S.C.

8. Water-quality sampling locations in the main stem, selected tributaries, and at point-source discharges to the Wateree River, S.C., June 23-25 and August 11-13, 1997.

9. Sample locations for the reaeration and time-of-travel studies on the Wateree River, S.C., June 24-25 and August 11-13, 1997

0. Drainage area of tributaries included in the water-quality model for the Wateree River, S.C.

11. Summary statistics for the streamflow calibration and validation simulations for the Wateree River, S.C. 
12. Simulated and measured peak travel time and dye-cloud area for six locations on the Wateree River, S.C., June 24-25 and August 11-13, 1997.

13. Rate constant coefficients, recommended values, and values used in the Branched Lagrangian Transport Model for the Wateree River, S.C.

14. Summary statistics for the simulated and measured concentrations used in the water-quality model calibration for seven locations on the Wateree River, S.C., June 23-25, 1997.

15. Summary statistics for the simulated and measured concentrations used in the water-quality model validation for seven locations on the Wateree River, S.C., August 11-13, 1997.

16. Sensitivity indices for the Branched Lagrangian Transport Model inputs for site 9 on the Wateree River, S.C., August 12, 1997

17. Simulated dissolved-oxygen concentrations (24-hour mean) for three streamflow conditions at eight locations on the Wateree River, S.C.

18. Simulated dissolved-oxygen concentrations for two point-source loading conditions at eight locations on the Wateree River, S.C.

19. Simulated dissolved-oxygen concentrations (24-hour mean) for three streamflow conditions assuming fully permitted effluent loads at eight locations on the Wateree River, S.C.

CONVERSION FACTORS, TEMPERATURE, AND VERTICAL DATUM

\begin{tabular}{rcl}
\hline Multiply & By & To obtain \\
\hline & Length & \\
inch (in.) & 25.4 & millimeter \\
foot (ft) & 0.3048 & meter \\
mile (mi) & 1.609 & kilometer \\
& Area & \\
acre & 4,047 & square meter \\
square mile $\left(\mathrm{mi}^{2}\right)$ & 2.590 & square kilometer \\
& Volume & \\
cubic foot (ft $\left.{ }^{3}\right)$ & 0.02832 & cubic meter \\
gallon & 3.785 & liter \\
acre-foot (acre-ft) & $1.233 \times 10^{3}$ & cubic meter \\
& Flow Rate & \\
million gallons per day (Mgal/d) & 1.547 & cubic foot per second \\
cubic foot per second (ft $\left.{ }^{3} / \mathrm{s}\right)$ & 0.02832 & cubic meter per second \\
\hline
\end{tabular}

\section{TEMPERATURE:}

Equations for temperature conversion between degrees Celsius $\left({ }^{\circ} \mathrm{C}\right)$ and degrees Fahrenheit $\left({ }^{\circ} \mathrm{F}\right)$ :

$$
\begin{gathered}
{ }^{\circ} \mathrm{C}=5 / 9\left({ }^{\circ} \mathrm{F}-32\right) \\
{ }^{\circ} \mathrm{F}=\left(1.8 \mathrm{x}^{\circ} \mathrm{C}\right)+32
\end{gathered}
$$

\section{SEA LEVEL:}

In this report, "sea level" refers to the National Geodetic Vertical Datum of 1929 (NGVD of 1929) - a geodetic datum derived from a general adjustment of the first-order level nets of both the United States and Canada, formerly called Sea Level Datum of 1929. 


\title{
Characterization of Water Quality and Simulation of Temperature, Nutrients, Biochemical Oxygen Demand, and Dissolved Oxygen in the Wateree River, South Carolina, 1996-98
}

\author{
By Toby D. Feaster and Paul A. Conrads
}

\begin{abstract}
In May 1996, the U.S. Geological Survey entered into a cooperative agreement with the Kershaw County Water and Sewer Authority to characterize and simulate the water quality in the Wateree River, South Carolina. Longitudinal profiling of dissolved-oxygen concentrations during the spring and summer of 1996 revealed dissolved-oxygen minimums occurring upstream from the point-source discharges. The mean dissolved-oxygen decrease upstream from the effluent discharges was 2.0 milligrams per liter, and the decrease downstream from the effluent discharges was 0.2 milligram per liter. Several theories were investigated to obtain an improved understanding of the dissolved-oxygen dynamics in the upper Wateree River. Data suggest that the dissolved-oxygen concentration decrease is associated with elevated levels of oxygenconsuming nutrients and metals that are flowing into the Wateree River from Lake Wateree.
\end{abstract}

Analysis of long-term streamflow and waterquality data collected at two U.S. Geological Survey gaging stations suggests that no strong correlation exists between streamflow and dissolved-oxygen concentrations in the Wateree River. However, a strong negative correlation does exist between dissolved-oxygen concentrations and water temperature. Analysis of data from six South
Carolina Department of Health and Environmental Control monitoring stations for 1980-95 revealed decreasing trends in ammonia nitrogen at all stations where data were available and decreasing trends in 5-day biochemical oxygen demand at three river stations.

The influence of various hydrologic and point-source loading conditions on dissolvedoxygen concentrations in the Wateree River were determined by using results from water-quality simulations by the Branched Lagrangian Transport Model. The effects of five tributaries and four pointsource discharges were included in the model. Data collected during two synoptic water-quality samplings on June 23-25 and August 11-13, 1997, were used to calibrate and validate the Branched Lagrangian Transport Model. The data include dyetracer concentrations collected at six locations, stream-reaeration data collected at four locations, and water-quality and water-temperature data collected at nine locations. Hydraulic data for the Branched Lagrangian Transport Model were simulated by using the U.S. Geological Survey BRANCH one-dimensional, unsteady-flow model. Data that were used to calibrate and validate the BRANCH model included time-series of waterlevel and streamflow data at three locations. The domain of the hydraulic model and the transport model was a 57.3- and 43.5-mile reach of the river, respectively. 
A sensitivity analysis of the simulated dissolved-oxygen concentrations to model coefficients and data inputs indicated that the simulated dissolved-oxygen concentrations were most sensitive to changes in the boundary concentration inputs of water temperature and dissolved oxygen followed by sensitivity to the change in streamflow. A 35-percent increase in streamflow resulted in a negative normalized sensitivity index, indicating a decrease in dissolvedoxygen concentrations. The simulated dissolvedoxygen concentrations showed no significant sensitivity to changes in model input rate kinetics.

To demonstrate the utility of the Branched Lagrangian Transport Model of the Wateree River, the model was used to simulate several hydrologic and water-quality scenarios to evaluate the effects on simulated dissolved-oxygen concentrations. The first scenario compared the 24-hour mean dissolved-oxygen concentrations for August 13, 1997, as simulated during the model validation, with simulations using two different streamflow patterns. The mean streamflow for August 13, 1997, was 2,000 cubic feet per second. Simulations were run using mean streamflows of 1,000 and 1,400 cubic feet per second while keeping the waterquality boundary conditions the same as were used during the validation simulations. When compared to the validation simulation using the mean streamflow for August 13, 1997, simulations indicated an increase in 24-hour mean dissolvedoxygen concentrations ranging from 0.26 to 0.47 milligram per liter and 0.12 to 0.30 milligram per liter, respectively. A dissolved-oxygen budget was computed at branch 1 grid 9 (river mile 57.4) for the three simulations. The budgets indicated that the increase in simulated dissolved-oxygen concentrations was a result of increased reaeration from the changing hydraulic conditions at the different flows.

A second scenario simulation was used to evaluate two point-source loading conditions to the system by comparing simulated dissolved-oxygen concentrations with a condition where there is no point-source discharge into the system. The changes in the 24-hour minimum and mean dissolved-oxygen concentrations for August 13, 1997, using the August 1997 validation flow conditions ranged from -0.08 to 0.05 milligram per liter. Setting all the point-source loadings to the current National Pollutant Discharge Elimination System permit ultimate oxygen demand levels changed the 24-hour minimum and mean dissolvedoxygen concentrations by a range of -0.26 to 0.01 milligram per liter.

A third scenario was run using the three different streamflow conditions from scenario one and setting point-source loadings to the current National Pollutant Discharge Elimination System permit ultimate oxygen demand levels. The results indicated increases in the 24-hour mean dissolvedoxygen concentrations ranging from 0.03 to 0.59 milligram per liter. Once again, the influence of the atmospheric reaeration as the flows were reduced resulted in increased 24-hour mean dissolved-oxygen concentrations.

\section{INTRODUCTION}

In recent years, South Carolina has experienced a significant increase in industrial and residential development. Along with the economic benefits that accompany such development, it is important to ascertain the effects of increased development on the State's natural resources and, in particular, its water resources. Although many factors must be examined for proper management of the State's water resources, the capacity of a stream to assimilate wastewater effluent without degrading overall water quality is one of the most important characteristics to be examined.

The headwaters of the Catawba-Wateree River Basin begin in western North Carolina at the foot of the Blue Ridge Mountains (fig. 1). The Catawba River flows into central South Carolina and becomes the Wateree River at Lake Wateree Dam located in Kershaw County.

Presently (1999), treated industrial and municipal wastewater is discharged into the upper Wateree River at four locations (fig. 2). Most wastewater discharges, although treated, still cause an increase in the demand for dissolved oxygen (DO) and a corresponding decrease in DO concentrations. If the release of treated wastewater is unregulated, DO concentrations may be reduced to levels that are unhealthy for aquatic life. To safeguard ecological health, point-source discharges are regulated in South Carolina by the Department of Health and 


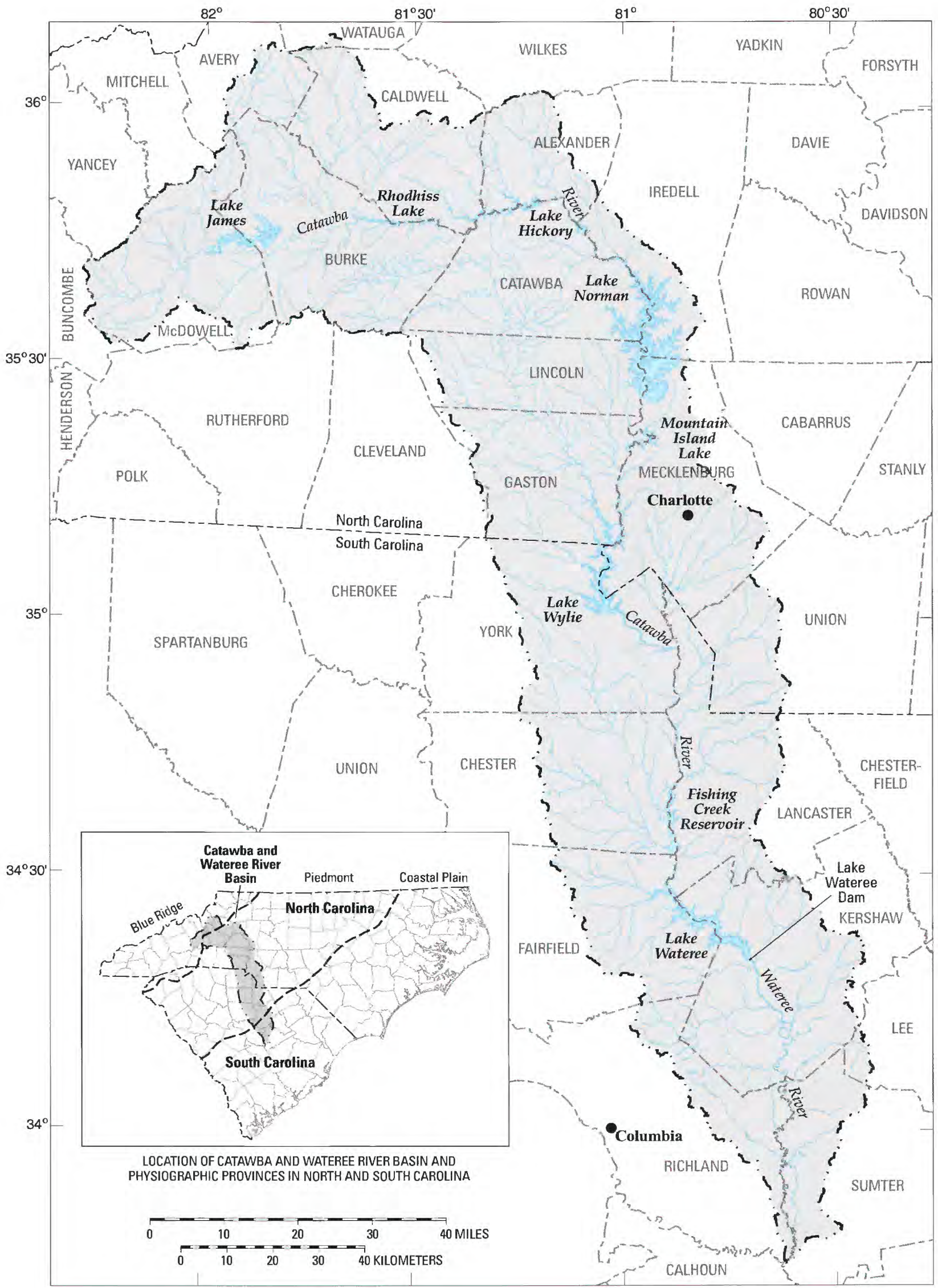

Figure 1. The Catawba-Wateree River Basin, in North and South Carolina. 


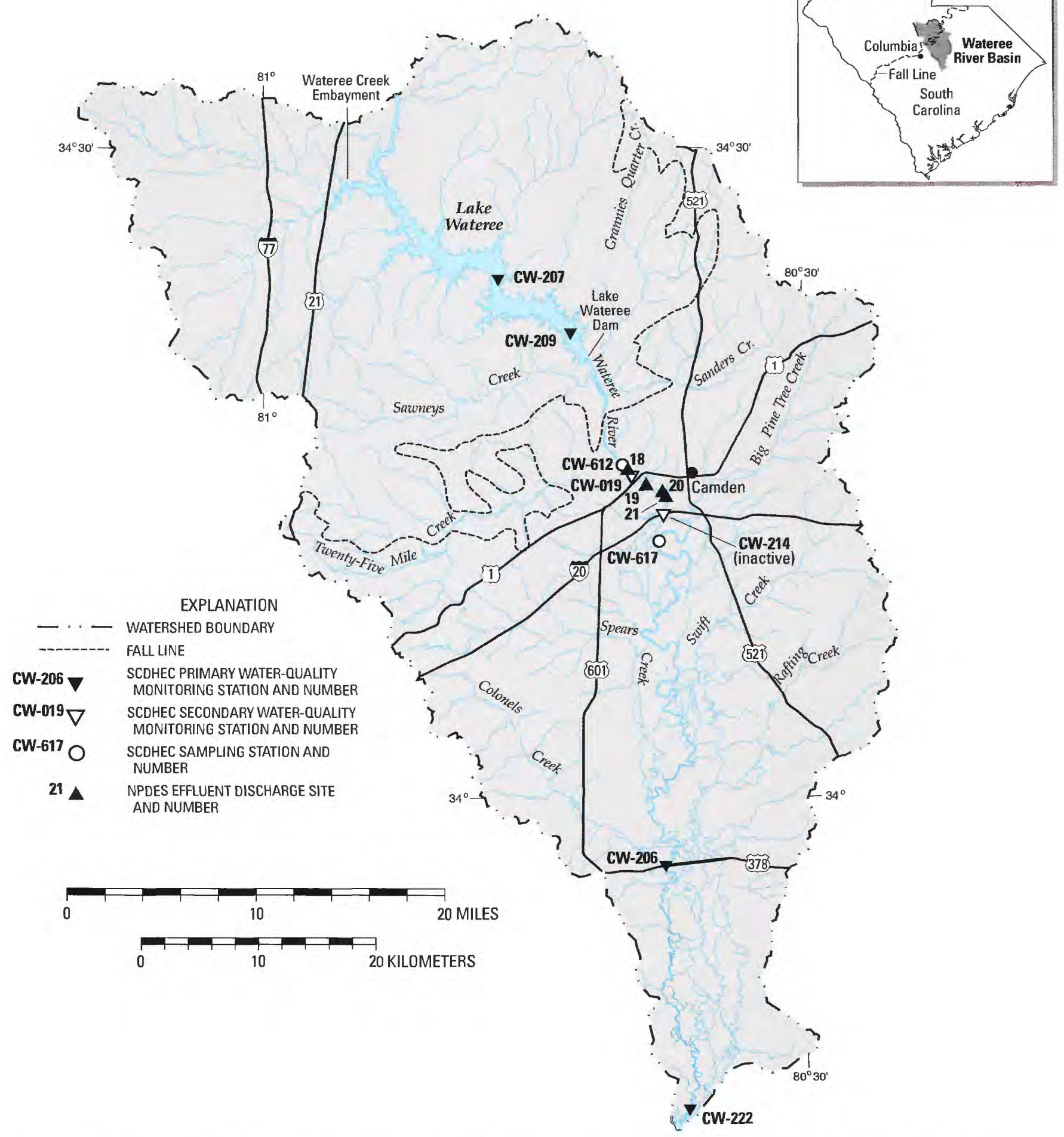

Figure 2. Locations of the South Carolina Department of Health and Environmental Control (SCDHEC) water-quality monitoring stations and National Pollutant Discharge Elimination System (NPDES) effluent discharge sites included in the Branched Lagrangian Transport Model (BLTM) for the Wateree River, S.C. 
Environmental Control (SCDHEC). Currently (1999), the quantity and quality of discharges allowed in the Wateree River are based on best professional judgment and results from a digital simulation model that predicts river conditions from approximately 2 miles (mi) upstream from U.S. 1/601 to Spears Creek (fig. 2). The SCDHEC currently uses the U.S. Environmental Protection Agency's (USEPA) QUAL2E model (Borders, 1984; Brown and Barnwell, 1987), which is a one-dimensional, steady-state flow, water-quality model that cannot simulate variations in releases from the Lake Wateree Dam (W. Cantrell, South Carolina Department of Health and Environmental Control, oral commun., 1999).

Models that can simulate unsteady flows, such as those released from the Lake Wateree Dam, estimate more accurately the dynamic conditions in the Wateree River. Consequently, in 1996 the U.S. Geological Survey (USGS), in cooperation with the Kershaw County Water and Sewer Authority (KCWSA), initiated a study to develop two digital models-(1) a hydraulic model to compute the unsteady hydraulic properties that are required for the (2) transport and water-quality model that will simulate the mass transport and fate of DO concentrations in a 43.5-mile reach of the Wateree River from approximately $1 \mathrm{mi}$ upstream from U.S. 1 to just downstream from U.S. 378 (fig. 2). The data computed with these models can be used by water-resource managers to estimate the effects of selected flows and point-source effluent loadings on DO concentrations in the Wateree River.

\section{Purpose and Scope}

This report presents the results of a review of historical data from the Wateree River and the application of the one-dimensional, unsteady flow model (BRANCH) (Schaffranek and others, 1981) and the Branched Lagrangian Transport Model (BLTM) (Jobson and Schoelhamer, 1987; Jobson, 1997) to a 57.3- and 43.5-mile reach of the Wateree River, respectively. The modeling effort was completed in two phases. The scope of the first phase was to calibrate and validate the BRANCH model and the BLTM to simulate the movement of a conservative constituent in the system. A conservative constituent is a constituent that is not chemically transformed over time. Consequently, the changes in the constituent as it moves downstream would be due to dispersion and not to decay or chemical transformation. The scope of the second phase was to calibrate and validate the BLTM to simulate the fate and transport of non-conservative constituents such as nutrients, biochemical oxygen demand (BOD), and DO.

\section{Approach}

DO concentration is one of the primary waterquality constituents that is used as an indicator of the ecological health of a waterbody. The ability to simulate DO concentrations in water is necessary for water-resource managers to assess the effects of pointand nonpoint-source pollution. The models described in this report can be used by water-resource managers to assess the assimilative capacity of the Wateree River.

The capacity of a stream to assimilate oxygendemanding substances is a function of DO, streamflow, temperature, velocity, depth, and channel configuration. In terms of water-resource management, this capacity, or loading, is expressed in terms of pounds per day of ultimate oxygen demand (UOD) that can be assimilated during a selected set of hydrologic conditions without violating the State water-quality standards for DO.

To maximize the use of historical data and to design a cost-effective data-collection program, the study was completed in two phases. The first phase, which occurred between May 1996 and June 1997, consisted of compiling and reviewing historical hydrologic and water-quality data and collecting longitudinal profiles of DO concentrations to characterize the water-quality dynamics of the river. This information was used to plan the second phase, which occurred between June 1997 and March 1999, and consisted of the calibration and validation of the streamflow and transport models.

\section{Previous Studies}

Several environmental, hydrologic, and modeling studies of the Catawba and Wateree River watersheds have been conducted. In 1982 and 1983, SCDHEC applied the QUAL-II water-quality model, which was an earlier version of the QUAL2E model, to the Wateree River and recommended wasteload allocations for point-source discharges into the river. The domain of the model extended from the STORET ${ }^{1}$

${ }^{1}$ STORET is the U.S. Environmental Protection Agency's STOrage and RETrieval Water Quality Data Base. 
water-quality monitoring station, CW-612, approximately 2 mi upstream from the U.S. 1 bridge to STORET station CW-617, approximately $2.5 \mathrm{mi}$ downstream from the confluence with Big Pine Tree Creek (fig. 2). To support the modeling effort, SCDHEC collected water-quality data and performed time-of-travel and reaeration studies. Results of the field study, model calibration and application, statistical analysis, and wasteload allocation are documented in Borders (1984). In the late 1980's, the USGS, in cooperation with several State agencies and power companies, applied the BRANCH model (Schaffranek and others, 1981) and the BLTM (Jobson and Schoelhamer, 1987) to the Wateree River to study the transport of striped bass eggs (Hurley, 1991).

The rapid urban growth in the Catawba River watershed, particularly in the Charlotte, N.C., metropolitan area, has caused concern about the effects of increasing point- and nonpoint-source loadings on the water quality of Lake Wateree. The SCDHEC, through financial assistance from the USEPA, classifies the State's publicly owned lakes according to water quality. Of the 16 major lakes (surface area greater than 850 acres) in South Carolina, Lake Wateree was found to be the most eutrophic (South Carolina Department of Health and Environmental Control, 1996a).

Phosphorus concentrations in Lake Wateree are among the highest measured in South Carolina lakes. On the basis of data from these investigations (1980-81, 1985-86, and 1989-90), the SCDHEC concluded that the trophic state of the forebay of Lake Wateree has improved, the headwaters have changed little, if any, and the Wateree Creek embayment (fig. 2) has become more eutrophic. Of particular concern relative to the water quality of the lake is the nonpoint-source loading of nutrients and sediments in the watershed, as indicated by occurrences of elevated nutrient concentrations and elevated turbidity levels.

The Departments of Environmental Health Sciences and Civil and Environmental Engineering of the University of South Carolina applied a onedimensional dynamic water-quality reservoir model to simulate the effects of changing loading conditions in the watershed, by point or nonpoint sources, on water quality in Lake Wateree (Tufford and others, 1997). The results indicated that a 15 -percent increase in point-source nutrient loading increased growingseason mean chlorophyll $a$ concentrations to levels greater than 25 micrograms per liter $(\mu \mathrm{g} / \mathrm{L})$, the upper- limit reference level identified for southeastern impoundments by Raschke (1994). The maximum simulated concentration, however, did not exceed $40 \mu \mathrm{g} / \mathrm{L}$, the reference level used by the State of North Carolina as a water-quality standard. A 75-percent increase in upstream nutrient loading from point and nonpoint sources resulted in increased mean chlorophyll $a$ concentrations of $30 \mu \mathrm{g} / \mathrm{L}$ and maximum concentrations greater than $40 \mu \mathrm{g} / \mathrm{L}$.

\section{Description of Study Area}

Wateree River streamflow is controlled by releases from the Lake Wateree Dam. Lake Wateree, the southernmost of 11 major reservoirs located along the Catawba River, is used for power generation, water supply, and recreation. Lake Wateree has a surface area of 13,710 acres, a volume of approximately 310,000 acre-feet (South Carolina Water Resources Commission, 1983), and a maximum and mean depth of $64.0 \mathrm{feet}(\mathrm{ft}$ ) and $22.6 \mathrm{ft}$, respectively (South Carolina Department of Health and Environmental Control, 1996b). The study area discussed in this report includes the 63.7-mi reach of the Wateree River from Lake Wateree Dam, river mile (RM) 73.8, to the USGS gaging station 02148315 near RM 10 below Eastover, S.C. (fig. 3). The drainage area of the Wateree River at the Lake Wateree Dam is approximately 4,750 square miles $\left(\mathrm{mi}^{2}\right)$ and includes the rapidly growing metropolitan area of Charlotte, N.C. (fig. 1). The drainage area increases by about 18 percent between the upstream and downstream study limits, from approximately 4,750 to $5,590 \mathrm{mi}^{2}$, respectively.

Approximately 3 mi downstream from the Lake Wateree Dam, the Wateree River crosses the Fall Line (fig. 2), which is the name given to the boundary between the Piedmont and upper Coastal Plain physiographic provinces. In general, this boundary is characterized by a series of rapids or falls where the streams tumble off the more resistant rocks of the Piedmont into the deeper valleys worn in the softer sediments of the Coastal Plain (Cooke, 1936). An area of rocky shoals lies between the Lake Wateree Dam and the Fall Line, where the channel is relatively wide, shallow, and steeply sloped (approximately 2.8 feet per mile [ft/mi]) (fig. 4). Downstream from the Fall Line, the channel slope flattens to an average of $0.8 \mathrm{ft} / \mathrm{mi}$, and the river narrows from a width of approximately 


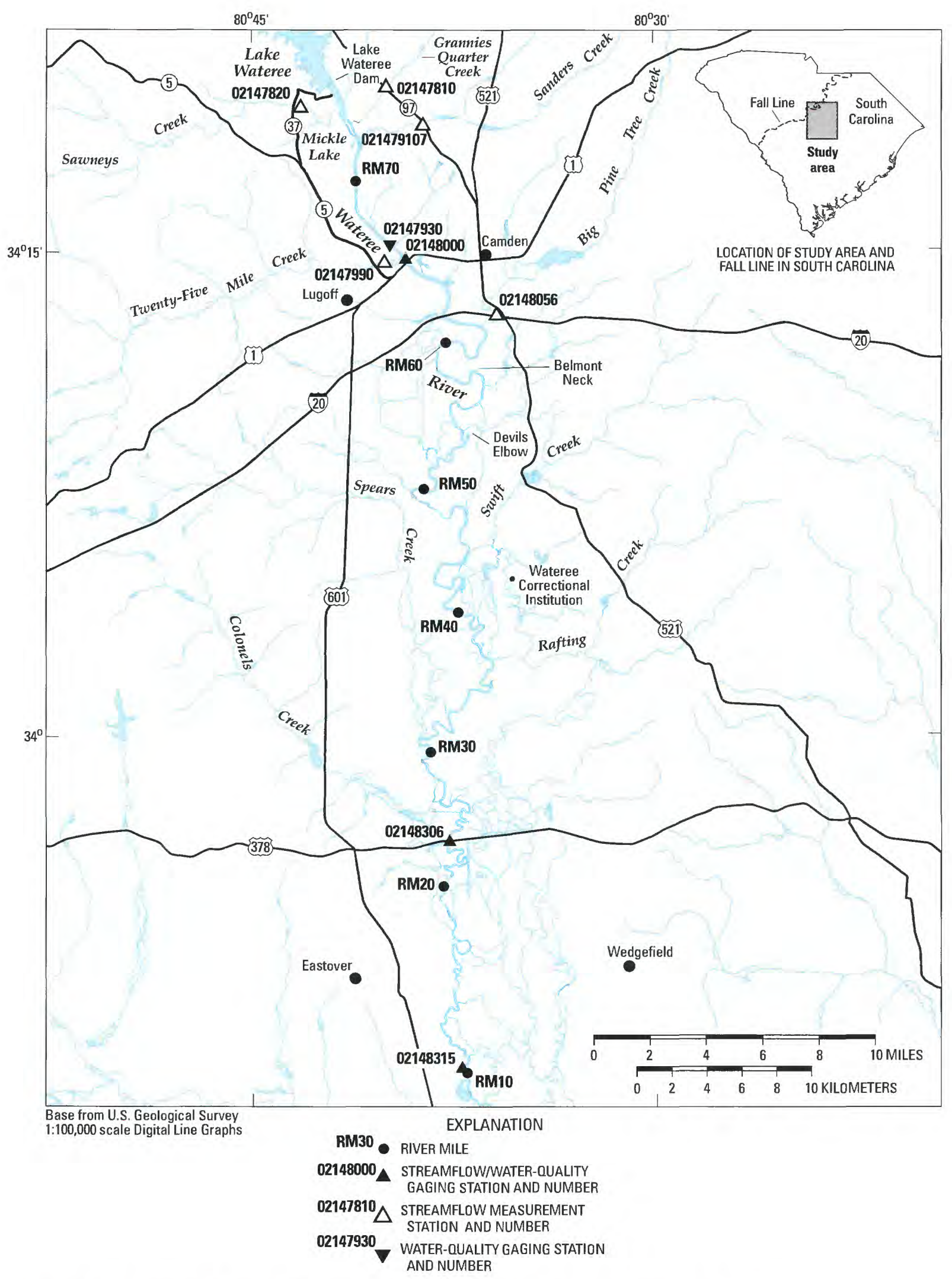

Figure 3. Locations of gaging stations and selected tributaries on the Wateree River, S.C. 


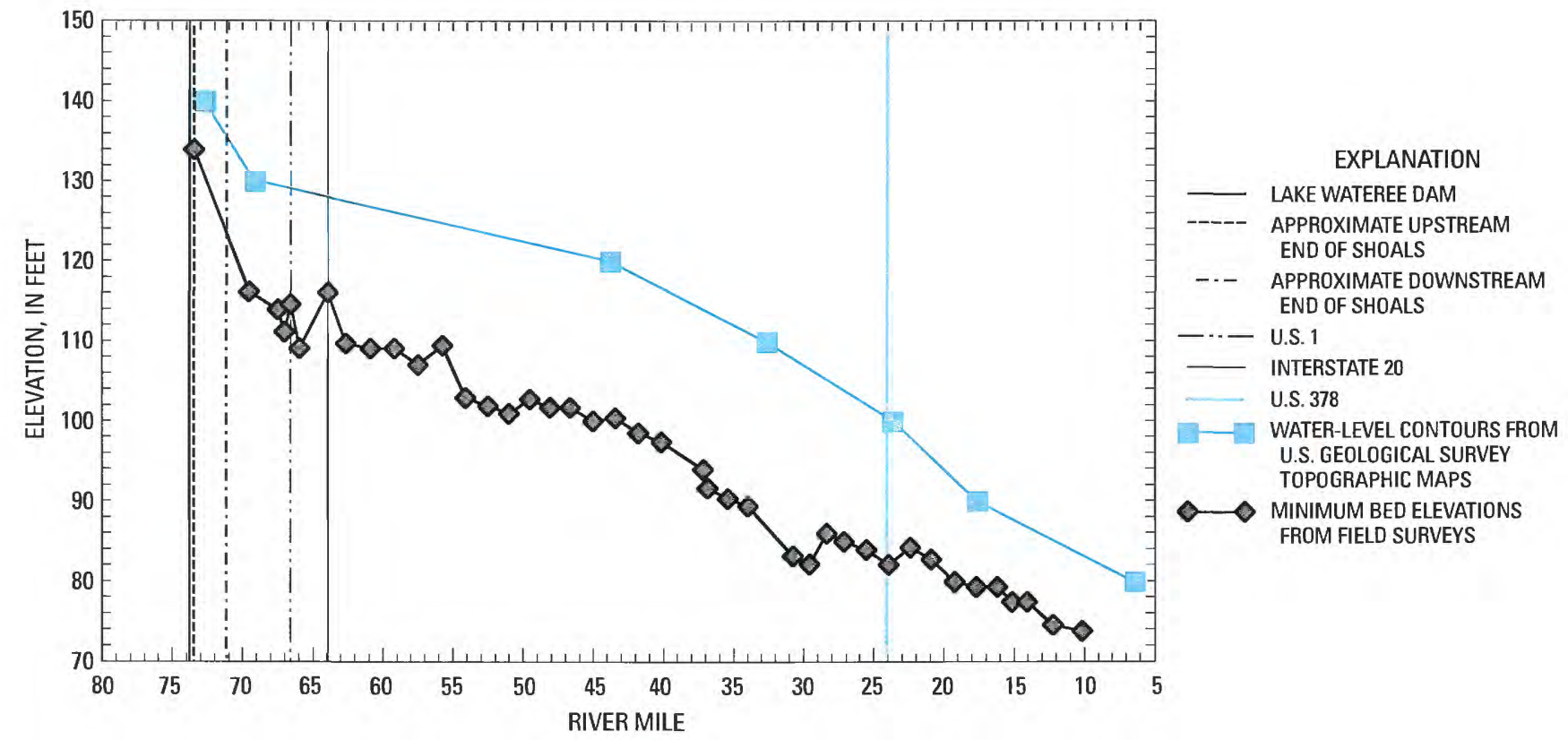

Figure 4. Minimum bed elevations at surveyed cross sections on the Wateree River, S.C., and U.S. Geological Survey topographic map contours that intersect the river.

$1,200 \mathrm{ft}$ to $450 \mathrm{ft}$ and becomes deeper. As the river flows into the upper Coastal Plain below Camden, S.C., it becomes more sinuous (fig. 2) and is bounded on both sides by large swamps.

During site visits between May 1996 and August 1997, the shoal area typically was inaccessible by boat. However, during a site visit to the Lake Wateree Dam tailrace on August 14, 1997, the shoal area was accessible by foot because no turbines were being operated at the dam and apparently had not been for several hours. A field investigation was conducted in the shoal area where a substantial community of macrophytes was discovered, which largely consisted of Potamogeton nodosus and Najas quadalupensis (Godfrey and Wooten, 1979). The macrophytes are dominant from approximately RM 72 to RM 73. This discovery suggests that the increases in DO concentrations, documented by the USGS at or near RM 71.1 during the spring and summer of 1996 and during synoptic water-quality samplings in June and August 1997, were a result of plant photosynthesis. In addition, DO concentrations measured during pre-dawn hours in June and August 1997 indicated significant atmospheric reaeration (DO concentrations increased by approximately $2 \mathrm{mg} / \mathrm{L}$ ) through the shoal area.
Several tributaries enter the Wateree River within the study area. The major tributaries are Grannies Quarter, Sawneys, Sanders, Twenty-Five Mile, Big Pine Tree, Swift, Rafting, Spears, and Colonels Creeks (fig. 3). The drainage areas of these streams range from 41.6 to $125 \mathrm{mi}^{2}$ (table 1). Grannies Quarter and Sawneys Creeks drain Piedmont soils, while the remaining streams drain Coastal Plain soils.

Table 1. Drainage areas of major tributaries to the Wateree River, S.C.

\begin{tabular}{lc}
\hline $\begin{array}{c}\text { Tributaries in } \\
\text { downstream order from } \\
\text { Lake Wateree Dam }\end{array}$ & $\begin{array}{c}\text { Drainage area } \\
\text { at mouth } \\
\text { (square miles) }\end{array}$ \\
\hline Grannies Quarter Creek & 70.7 \\
Sawneys Creek & 58.4 \\
Sanders Creek & 41.6 \\
Twenty-Five Mile Creek & 125 \\
Big Pine Tree Creek & 65.3 \\
Swift Creek & 62.3 \\
Rafting Creek & 54.8 \\
Spears Creek & 70.8 \\
Colonels Creek & 69.9 \\
\hline
\end{tabular}




\section{Acknowledgments}

The data-collection phase of this project produced approximately 4,900 measurements of water-quality constituents and 1,500 in situ measurements of waterquality data. Samples were collected from a 51-mi reach of the Wateree River, from Lake Wateree just upstream from the dam, and from the effluents of four point-source discharges. Accomplishing this major task involved the efforts of 28 USGS personnel, 11 local volunteers, 11 landowners, and representatives of four point-source dischargers and Duke Energy. The authors extend thanks to all who were involved. The authors commend the Wateree River community for its willingness to assist in this project. In particular, the authors thank Lauren Corr, Chairman of the Kershaw County Water and Sewer Authority, for his leadership and assistance during this project. In addition, William Stroud, manager of the Catawba River reservoir system for Duke Energy, provided valuable assistance concerning coordination of releases from the Lake Wateree Dam during this project.

\section{CHARACTERIZATION OF STREAMFLOW AND WATER QUALITY}

The water quality of the Wateree River was characterized by compiling and reviewing historical hydrologic and water-quality data, and by collecting longitudinal profiles of DO concentrations during the spring and summer of 1996. The longitudinal profiles were measured to define the spatial DO concentration distribution in the Wateree River. Historical streamflow data that were measured at USGS station 02148000 (fig. 3) were reviewed to assess flow variations. Statistical methods were used to analyze water-quality data collected at six stations monitored by the SCDHEC (table 2; fig. 2). In addition, flow and transport models from a previous study (Hurley, 1991) were used in planning the water-quality sampling.

\section{Historical Flow Trends}

Lake Wateree was constructed in 1919 and was enlarged in 1925 (South Carolina Water Resources Commission, 1983). Since 1929, the USGS has continuously monitored water levels at station 02148000 , approximately $7 \mathrm{mi}$ downstream from the Lake Wateree Dam. Because the travel time between the dam and station 02148000 is relatively short, data from the gage are useful in assessing streamflow fluctuations caused by the dam.

An analysis was made by using the monthly daily-mean streamflow percentiles $(0,5$ th, 10 th, 25 th, 50th, 75th, 90th, 95th, and 100th) at station 02148000 from 1929 through 1997. A 5th-percentile flow indicates that 95 percent of the daily-mean streamflow equals or exceeds this value for a given month. The 0 and 100th percentiles represent the minimum and

Table 2. South Carolina Department of Health and Environmental Control water-quality monitoring stations on Lake Wateree and the Wateree River, S.C.

[P. primary (sampled monthly throughout year); FW, freshwater; mi, mile; S, secondary (sampled monthly from May-October); RM, river mile; I, inactive]

\begin{tabular}{|c|c|c|c|c|}
\hline $\begin{array}{c}\text { Station } \\
\text { no. } \\
\text { (fig. 2) }\end{array}$ & $\begin{array}{l}\text { Length of } \\
\text { record used in } \\
\text { analysis }\end{array}$ & Type & Classification & Description \\
\hline CW-207 & $1980-95$ & $\mathrm{P}$ & FW & $\begin{array}{l}\text { Lake Wateree from east side of Lake Wateree approximately } 7.7 \mathrm{mi} \\
\text { upstream from Wateree Dam }\end{array}$ \\
\hline CW-209 & $1980-95$ & $\mathrm{P}$ & FW & Lake Wateree at small island $2.3 \mathrm{mi}$ north from Wateree Dam \\
\hline CW-019 & $1982-95$ & $S$ & FW & Wateree River at U.S. 1 (RM 66.6) \\
\hline CW-214 & $1982-89$ & $\mathrm{~S}(\mathrm{I})$ & FW & Wateree River at Interstate 20 (RM 63.9) \\
\hline CW-206 & $1980-95$ & $\mathrm{P}$ & FW & Wateree River at U.S. 378 (RM 24.0) \\
\hline CW-222 & $1980-95$ & $\mathrm{P}$ & FW & $\begin{array}{l}\text { Wateree River at } 1.6 \text { mi upstream from confluence with Congaree } \\
\text { River (RM 1.6) }\end{array}$ \\
\hline
\end{tabular}


maximum values, respectively. The daily-mean streamflow for each percentile and month is shown in figure 5 and listed in table 3 . Variations in the monthly streamflow for the given percentiles are relatively small, which suggest that releases from the Lake Wateree Dam are fairly consistent throughout the year. The exception to this is the 100th-percentile streamflow, which indicates flood conditions when the flow was over the spillway.

The daily-mean streamflow for weekend (Saturday and Sunday) and weekday (Monday through Friday) flows at USGS station 02148000 were compared. Ratios of the median weekend flow to the median 7-day weekly flow were computed for a given water year ${ }^{2}$. In addition, a ratio of the median weekday flow to the median 7-day weekly flow was computed (fig. 6). A significant change in the weekend flow to 7-day weekly flow ratio occurred between 1970 and 1997 (fig. 6). In recent years, it appears that the median weekend flows have been converging to the median weekday flows. Duke Energy officials indicated that no concerted effort has been made to change the weekend flow patterns (William Stroud, Duke Energy, written

\footnotetext{
${ }^{2} \mathrm{~A}$ water year is the period from October 1 to September 30 and is identified by the year in which it ends.
}

commun., 1998). Stroud noted that during the dates included in the statistical analysis, the functions of the hydroelectric plants changed from mainly base-load power generation to more varied power generation in order to meet peak energy needs.

\section{Historical Water-Quality Trends}

Water-quality data were retrieved from the USEPA STORET data base for six SCDHEC surfacewater monitoring stations (table 2; fig. 2). Two of these stations (CW-207 and CW-209; fig. 2) are located in Lake Wateree, and they were included in the analysis to obtain information on the quality of water before it enters the Wateree River. The Kendall Tau statistical analysis was used to detect statistically significant trends in DO, percent saturation DO, total Kjeldahl nitrogen (TKN), ammonia nitrogen, nitrite plus nitrate nitrogen, total phosphorus, total organic carbon (TOC), 5-day biochemical oxygen demand $\left(\mathrm{BOD}_{5}\right)$, low-level chemical oxygen demand, fecal coliform, total iron, total manganese, and turbidity. A p-value of less than 0.05 indicated a significant trend. The results of the analysis are listed in table 4 . The constituents used most by the SCDHEC to determine a stream's

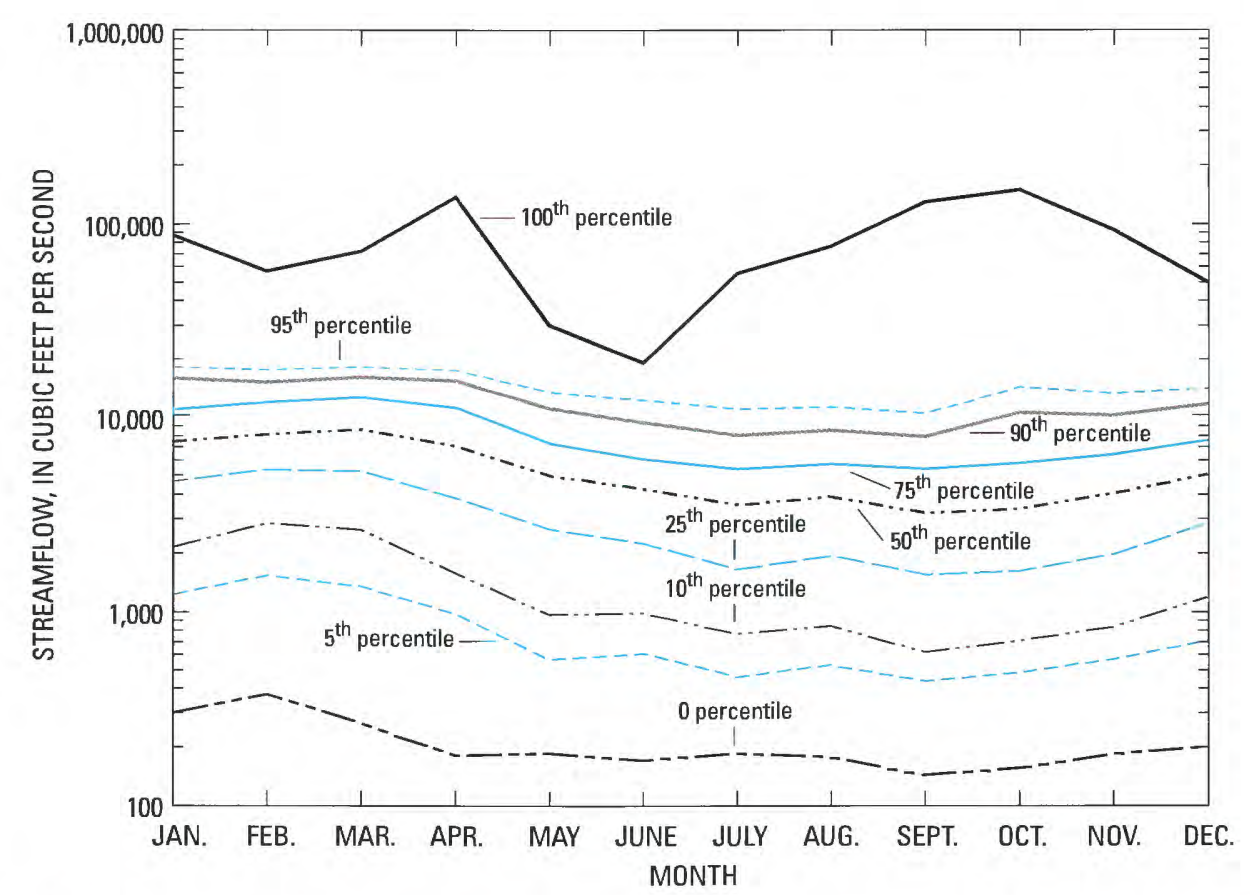

Figure 5. Monthly daily-mean streamflow at USGS station 02148000 , Wateree River at Camden, S.C., 1929-97. 
Table 3. Monthly daily-mean streamflow percentiles at USGS station 02148000, Wateree River at Camden, S.C., 1929-97 [Units in cubic feet per second]

\begin{tabular}{|c|c|c|c|c|c|c|c|c|c|}
\hline Month & $\begin{array}{c}0- \\
\text { percentile } \\
\text { flow }\end{array}$ & $\begin{array}{l}\text { 5th- } \\
\text { percentile } \\
\text { flow }\end{array}$ & $\begin{array}{l}\text { 10th- } \\
\text { percentile } \\
\text { flow }\end{array}$ & $\begin{array}{c}25 \text { th- } \\
\text { percentile } \\
\text { flow }\end{array}$ & $\begin{array}{l}\text { 50th- } \\
\text { percentile } \\
\text { flow }\end{array}$ & $\begin{array}{l}\text { 75th- } \\
\text { percentile } \\
\text { flow }\end{array}$ & $\begin{array}{l}\text { 90th- } \\
\text { percentile } \\
\text { flow }\end{array}$ & $\begin{array}{l}\text { 95th- } \\
\text { percentile } \\
\text { flow }\end{array}$ & $\begin{array}{l}\text { 100th- } \\
\text { percentile } \\
\text { flow }\end{array}$ \\
\hline January & 302 & 1,230 & 2,150 & 4,630 & 7.450 & 11.500 & 16,000 & 17,900 & 86,600 \\
\hline February & 374 & 1,520 & 2,860 & 5,290 & 8,150 & 12,400 & 15,500 & 17,500 & 56,900 \\
\hline March & 266 & 1,340 & 2,690 & 5,710 & 8,540 & 13.200 & 16,600 & 18,200 & 72,200 \\
\hline April & 179 & 966 & 1,580 & 3,790 & 6,980 & 11,500 & 15,800 & 17,300 & 137,000 \\
\hline May & 187 & 566 & 990 & 2,630 & 5,000 & 7.600 & 11.000 & 13,400 & 30,000 \\
\hline June & 170 & 600 & 988 & 2,230 & 4,270 & 6,270 & 9,380 & 12,200 & 19,100 \\
\hline July & 187 & 454 & 794 & 1,640 & 3,540 & 5,610 & 8.120 & 10,900 & 55,500 \\
\hline August & 178 & 521 & 850 & 1,920 & 3,840 & 5,930 & 8,600 & 11,100 & 76,200 \\
\hline September & 143 & 430 & 635 & 1,550 & 3,215 & 5,580 & 8.000 & 10.500 & 129,000 \\
\hline October & 155 & 478 & 720 & 1,610 & 3,380 & 5,950 & 10,500 & 14,200 & 149,000 \\
\hline November & 182 & 560 & 838 & 1,990 & 4,040 & 6,640 & 10.200 & 13,200 & 92,900 \\
\hline December & 202 & 699 & 1,190 & 2,790 & 5,030 & 7,820 & 11,700 & 14,100 & 49,900 \\
\hline
\end{tabular}

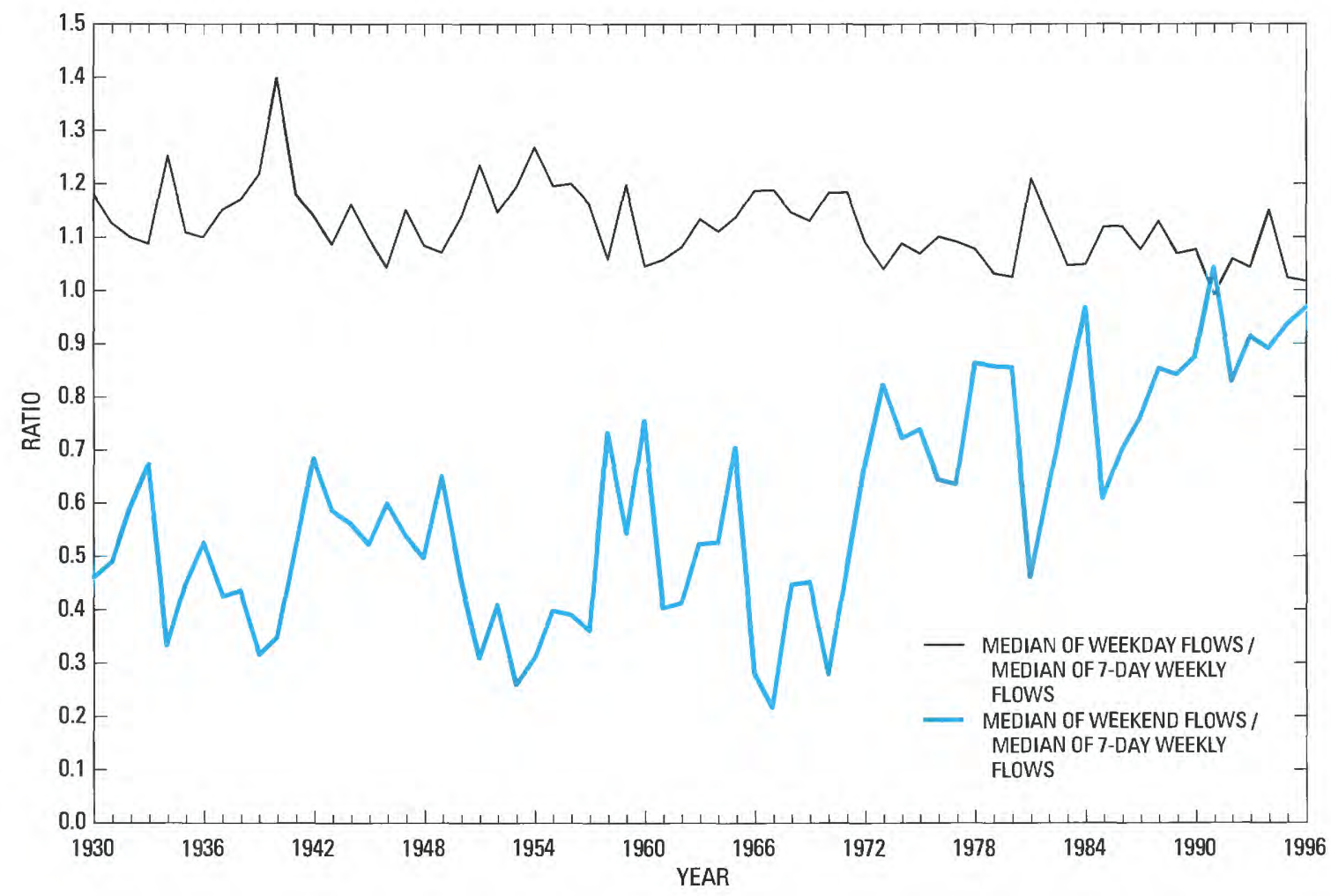

Figure 6. Comparison of median weekday and median weekend streamflow as a ratio of the water-year median 7-day weekly streamflow at USGS station 02148000 on the Wateree River, S.C. 


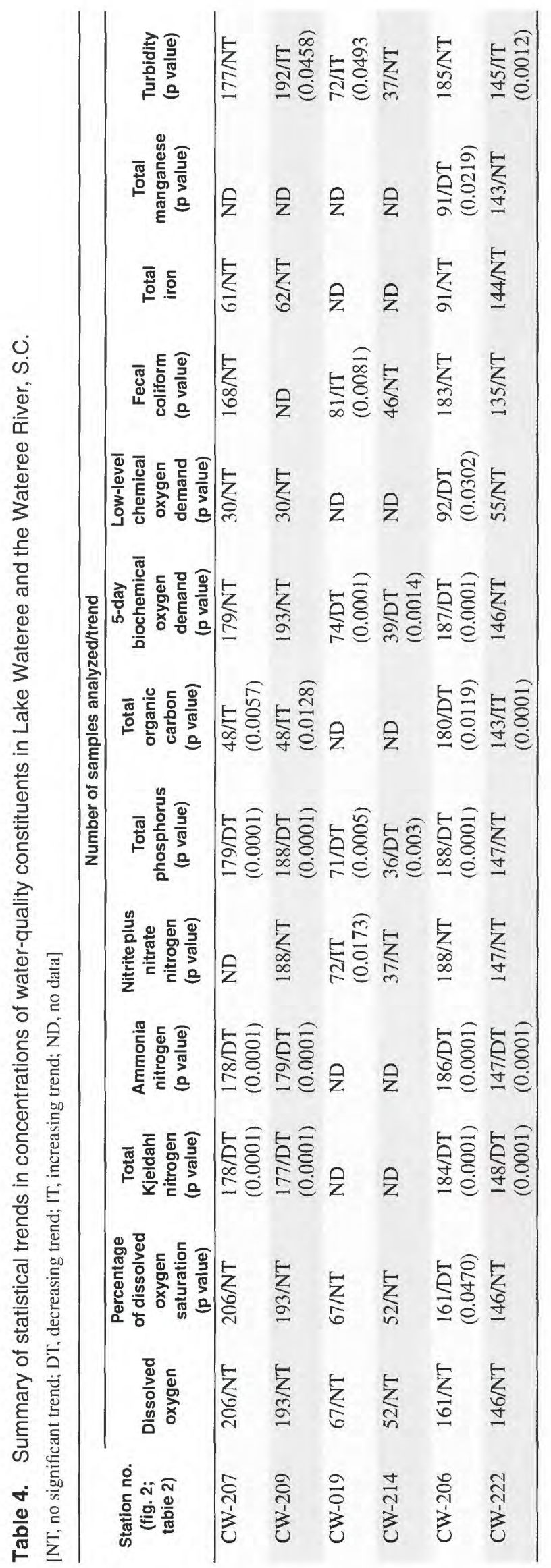


assimilative capacity are DO, ammonia nitrogen, and $\mathrm{BOD}_{5}$. The statistical analysis indicated that no significant trend in DO concentrations occurred at any of the stations; decreasing trends in ammonia nitrogen occurred at all stations where data were available; and decreasing trends in $\mathrm{BOD}_{5}$ occurred at three river stations (table 2). In addition, an increasing trend in turbidity occurred at one lake station and two river stations; increasing trends in TOC occurred at two lake stations and one river station, and a decreasing trend in TOC occurred at one river station; decreasing trends in total phosphorus occurred at all stations where data were available; and decreasing trends in TKN occurred at all stations where data were available. It should be noted that although DO was included in the trend analysis, the upper Wateree River stations are influenced by diel variations in DO. As a result, determining a trend in DO based on monthly monitoring data would be very difficult.

A stepwise regression analysis was used to relate DO concentrations to water temperature and streamflow at stations 02148000 and 02148315 (fig. 3). The USGS has continuously monitored DO concentrations and water temperature at stations 02148000 since 1991 and 02148315 since 1970 . Water level has been continuously monitored at these two stations since 1929 and 1968, respectively. At station 02148000 , the daily-minimum DO concentration was correlated with the daily-mean water temperature and daily-mean streamflow. A second analysis was made using the daily-mean DO concentrations, daily-mean water temperature, and daily-mean streamflow. The dailyminimum and daily-mean DO concentrations at both stations had a significant negative correlation with water temperature, as indicated by the high coefficient of determination $\left(\mathrm{r}^{2}\right)$ value (table 5). The coefficient of determination is defined as the proportion of variability in the dependent variable that is accounted for by the independent variables (Ott, 1993). In this analysis, the DO concentration was the dependent variable, and streamflow and water temperature were the independent variables. Water temperature was the dominant variable, explaining 92 percent and 85 percent of the relation with DO concentrations at stations 02148000 and 02148315 , respectively (table $5)$. When streamflow was added to the correlation analysis at station 02148000 , the improvement in the $r^{2}$ value was negligible, ranging from 0.001 to 0.011 . Because of an extensive swamp east of the river, the
Table 5. Stepwise regression analysis of daily-minimum and daily-mean dissolved oxygen, daily-mean water temperature, and daily-mean streamflow at USGS stations 02148000 and 02148315 on the Wateree River, S.C.

[ $\mathrm{r}^{2}=$ coefficient of determination]

\begin{tabular}{|c|c|c|c|c|c|}
\hline \multirow{2}{*}{$\begin{array}{l}\text { Station no. } \\
\text { (fig. 3) }\end{array}$} & \multirow{2}{*}{$\begin{array}{c}\text { Dissolved } \\
\text { oxygen }\end{array}$} & \multicolumn{2}{|c|}{$\begin{array}{c}\text { Water } \\
\text { temperature }\end{array}$} & \multicolumn{2}{|c|}{$\begin{array}{c}\text { Water } \\
\text { temperature and } \\
\text { streamflow }\end{array}$} \\
\hline & & $r^{2}$ & $\begin{array}{c}\text { Standard } \\
\text { error }\end{array}$ & $r^{2}$ & $\begin{array}{c}\text { Standard } \\
\text { error }\end{array}$ \\
\hline 02148000 & Daily minimum & 0.915 & 0.70 & 0.923 & 0.67 \\
\hline 02148000 & Daily mean & .917 & .64 & .918 & .63 \\
\hline 02148315 & Daily minimum & .854 & .69 & \multicolumn{2}{|c|}{ No regression } \\
\hline 02148315 & Daily mean & .846 & .70 & \multicolumn{2}{|c|}{ No regression } \\
\hline
\end{tabular}

rating curve for station 02148315 is applicable for flows, confined to the main channel, of less than about 10,000 cubic feet per second $\left(\mathrm{ft}^{3} / \mathrm{s}\right)$. Consequently, the daily-mean and daily-minimum DO concentrations at station 02148315 were correlated with water temperature only.

The daily-mean and daily-minimum DO concentrations at stations 02148000 and 02148315 also were analyzed for the percentage of time that the State DO standards were not met. The SCDHEC has classified the Wateree River as freshwater (FW), which has a daily-mean DO concentration standard of not less than 5.0 milligrams per liter $(\mathrm{mg} / \mathrm{L})$ and a dailyminimum standard of not less than $4.0 \mathrm{mg} / \mathrm{L}$ (South Carolina Department of Health and Environmental Control, 1993). At station 02148000, the daily-mean and daily-minimum DO concentrations were below the SCDHEC standards 19 and 15 percent of the time, respectively. At station 02148315, the daily-mean and daily-minimum DO concentrations were below the standard 2.4 and 0.3 percent of the time, respectively. The daily-mean streamflow during the periods when the DO concentrations were below the standard ranged from 631 to $24,300 \mathrm{ft}^{3} / \mathrm{s}$ at station 02148000 and from 967 to $9,960 \mathrm{ft}^{3} / \mathrm{s}$ at station 02148315 . As previously mentioned, the stage-discharge relation at station 02148315 is not applicable for streamflow exceeding $10,000 \mathrm{ft}^{3} / \mathrm{s}$. This analysis also suggests that the DO concentrations are not strongly correlated to streamflow. 


\section{Longitudinal Profiles of Dissolved- Oxygen Concentrations}

Series of longitudinal profiles were measured in the Wateree River during the spring and summer of 1996. The first DO profile was made on May 6, 1996, and began near RM 71.3 (fig. 3), which was the farthest upstream location accessible by boat from the U.S. 1 boat landing. A wide area of shoals starts near RM 73.5 , approximately $1,000 \mathrm{ft}$ downstream from the dam, and continues to about RM 71. This area of the river is only navigable during high flows. On May 6, 1996, the DO concentration was $7.6 \mathrm{mg} / \mathrm{L}$ at RM 71.3 (fig. 7). At RM 67.0, the DO concentration had decreased to $6.2 \mathrm{mg} / \mathrm{L}$. The minimum DO concentration during this profile was $6.1 \mathrm{mg} / \mathrm{L}$, which was measured at RM 65.8. The first effluent discharge downstream from Lake Wateree Dam is located at RM 67.1. Upstream from the first effluent discharge, the DO concentration on May 6, 1996, had decreased by $1.5 \mathrm{mg} / \mathrm{L}$ from RM 71.3. Downstream from the first effluent discharge, the DO concentration dropped another $0.1 \mathrm{mg} / \mathrm{L}$. Consequently, further investigations were made during spring and summer 1996 in an effort to better understand the dynamics of the DO concentrations in the upper reach of the Wateree River.

Nine longitudinal profiles were measured between May and September 1996, with similar results (fig. 7). The average streamflow recorded at USGS station 02148000 during the profiles ranged from 622 to $8,310 \mathrm{ft}^{3} / \mathrm{s}$ (table 6 ). This suggests that the decrease in DO concentrations was not strongly correlated with streamflow. The minimum DO concentrations during these profiles were measured at locations from RM 68.0 to RM 63.4. The decrease in DO concentrations from the sampling location near RM 71.1 to the location with the minimum DO concentration, ranged from 0.6 to $4.3 \mathrm{mg} / \mathrm{L}$, with a mean decrease of $2.0 \mathrm{mg} / \mathrm{L}$. The decrease in DO concentration just downstream from the first effluent discharge (RM 67.1) to the location of minimum DO concentration ranged from 0.0 to $0.5 \mathrm{mg} / \mathrm{L}$, with a mean decrease of $0.2 \mathrm{mg} / \mathrm{L}$. Consequently, data suggest that the effluent discharges had a minimal effect on DO concentrations, whereas something upstream from the effluent discharges had a significant effect on the DO concentrations.

During the summer of 1996 , several theories were investigated concerning the decrease in DO
Table 6. Average streamflow at USGS station 02148000, Wateree River at Camden, S.C., and beginning and ending sampling times during the longitudinal profiles of dissolved oxygen on the Wateree River, S.C.

$\left[\mathrm{ft}^{3} / \mathrm{s}\right.$, cubic foot per second; EST, Eastern Standard Time]

\begin{tabular}{lccc}
\hline Date & $\begin{array}{c}\text { Average } \\
\text { streamflow } \\
\left(\mathrm{ft}^{3} / \mathrm{s}\right)\end{array}$ & $\begin{array}{c}\text { Begin time } \\
(\text { EST) }\end{array}$ & $\begin{array}{c}\text { End time } \\
(\text { EST) }\end{array}$ \\
\hline $5-6-96$ & 3,600 & $08: 50$ & $11: 26$ \\
$6-27-96$ & 3,140 & $08: 28$ & $16: 33$ \\
$7-11-96$ & 622 & $08: 02$ & $12: 25$ \\
$7-22-96$ & 1,270 & $07: 43$ & $09: 54$ \\
$7-22-96$ & 1,720 & $10: 47$ & $12: 18$ \\
$8-8-96$ & 2,170 & $14: 09$ & $15: 37$ \\
$8-16-96$ & 8,310 & $10: 17$ & $14: 00$ \\
$9-10-96$ & 2,360 & $09: 00$ & $13: 18$ \\
$9-11-96$ & 4,840 & $07: 49$ & $11: 51$ \\
\hline
\end{tabular}

concentrations that occurred upstream from the effluent discharges: (1) effects from Lake Wateree, (2) nonpoint-source pollution, (3) sediment oxygen demand (SOD), (4) tributary inflow, and (5) BOD. Details of these investigations were presented to the KCWSA and SCDHEC in a study plan for this project (T. Feaster, U.S. Geological Survey, written commun., October 1996).

From data collected and analyzed during this study, the most probable theory concerning the decrease in DO concentrations upstream from the effluent discharges is that the water quality of the releases from Lake Wateree has a significant influence on the DO concentrations in the upper Wateree River. Water from Lake Wateree enters the turbines at the Lake Wateree Dam through an opening located at the base of the dam that is approximately $22 \mathrm{ft}$ high. To assess the quality of the lake water, vertical profiles of DO concentrations were measured approximately $200 \mathrm{ft}$ upstream from the dam on August 16 and September 10-11, 1996. The DO concentrations in the lower $20 \mathrm{ft}$ of the water column ranged from 1 to $2 \mathrm{mg} / \mathrm{L}$. On August 16, 1996, the $\mathrm{pH}$ ranged from 7.5 at the top of the water column to 6.5 at the bottom. During September 10-11, 1996, the differences between top and bottom $\mathrm{pH}$ were 0.5 and 0.4 units, respectively. During September 10-11, 1996, dissolved iron concentrations were measured in the lake and ranged from $0.4 \mathrm{mg} / \mathrm{L}$ at the top of the lake to $0.8 \mathrm{mg} / \mathrm{L}$ at the 


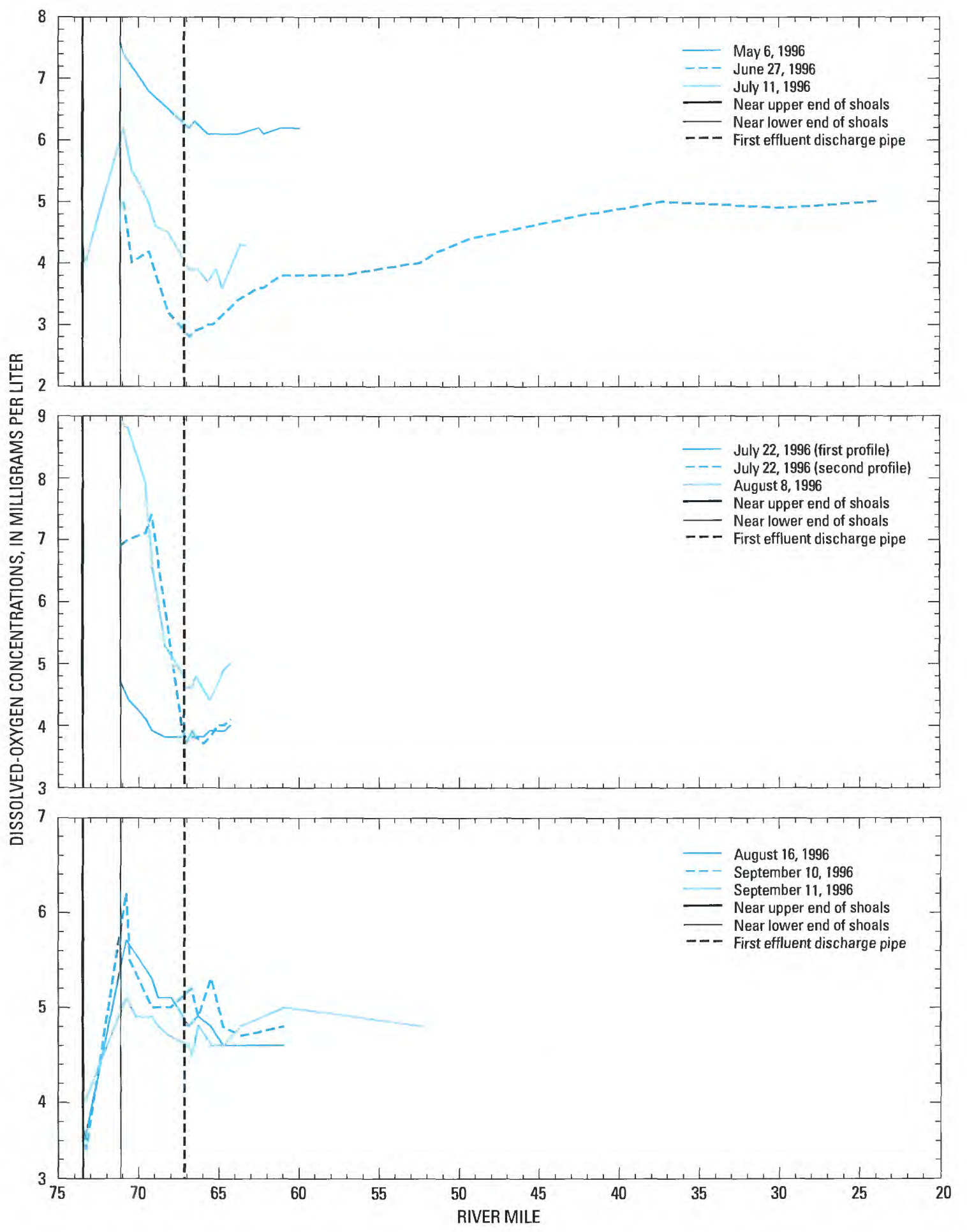

Figure 7. Longitudinal profiles of dissolved-oxygen concentrations in the Wateree River, S.C., May-September 1996. 
bottom. In addition, TKN concentrations ranging from 2 to $5 \mathrm{mg} / \mathrm{L}$ were measured in the lake. Consequently, the data suggest that the lake contains an abundance of organic material. It was hypothesized that once this material enters the river and encounters higher DO concentrations, oxidation begins and reduces the DO concentrations in the river. Significant reaeration occurs downstream from the dam because of a reach of shoals that begins approximately $700 \mathrm{ft}$ below the dam and tapers off near RM 71.1. In this reach, the reaeration rate exceeds the oxidation rate, thereby resulting in increased DO concentrations. Beyond the shoals, the oxidation rate overtakes the reaeration rate, and DO concentrations drop significantly. The oxidation rate then decreases as available DO and reducing species decrease.

During the spring and summer months, the upper Wateree River can experience significant diel fluctuations in DO concentrations (fig. 8). During initial reviews of the DO and water-temperature data at station 02148000 , it was surmised that the increase in DO under favorable light and temperature conditions was due to algal photosynthesis. However, chlorophyll $a$ samples collected in June and August
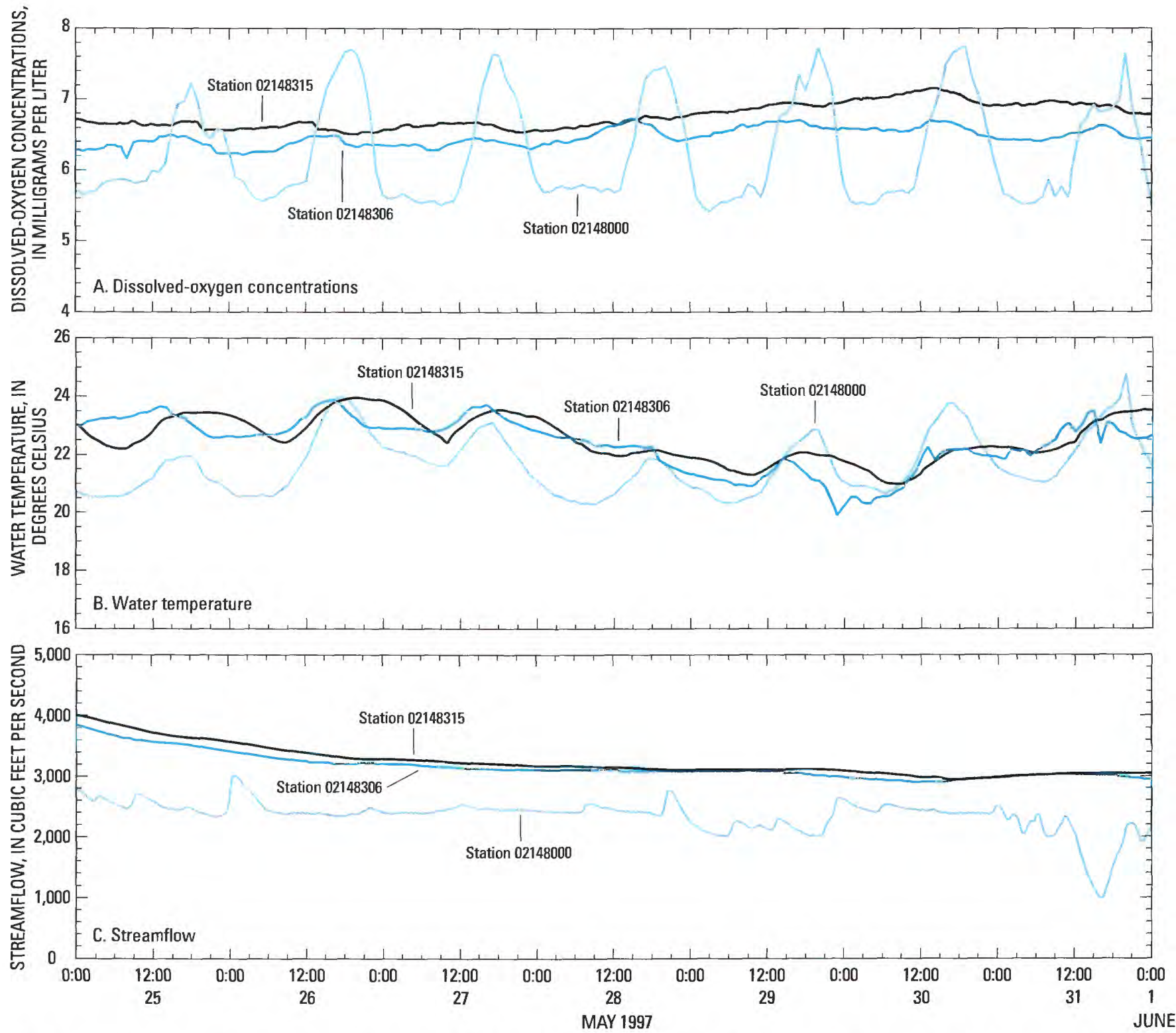

Figure 8. (A) Dissolved-oxygen concentrations, (B) water temperature, and (C) streamflow at three locations on the Wateree River, S.C., May 25-31, 1997. 
1997 suggest that algae were not a significant factor in the Wateree River. Although the diel variations in DO at the lower two stations were minor (fig. 8), no significant changes in chlorophyll $a$ concentrations were measured between the upper and lower Wateree River. Consequently, it was concluded that the diel fluctuations in DO at station 02148000 are associated with photosynthesis from macrophytes and not from algae. The measured chlorophyll $a$ samples along with the other water-quality data are presented in the Data Collection and Analysis section of this report.

The left (east) bank of the Wateree River from the dam to U.S. 1 is mainly forested. The right (west) bank consists of some forest and a substantial amount of row crops and pasture. Consequently, it was theorized that nonpoint-source pollution in the form of agricultural runoff might be depleting the DO concentrations in the upper Wateree River; however, this would have occurred during or shortly after a rainfall. Rainfall records at Camden, S.C., provided by the South Carolina Department of Natural Resources, were reviewed for the day of the longitudinal DO concentrations profiling and for 2 days prior. The records indicated that no substantial rainfall had occurred during or prior to the profiles for most of the sampling periods.

Under some circumstances, oxygen demand by benthic sediments and organisms can represent a large fraction of oxygen consumption in surface waters (Bowie and others, 1985). SOD is composed of biological and chemical components. The biological component in SOD reflects living organisms dwelling in the sediment in the benthic community. The chemical component in SOD results primarily from reactive and reduced inorganic constituents, such as iron, manganese, and sulfide (Wang, 1979). During September 10-11, 1996, bed-sediment samples were collected from Lake Wateree approximately $200 \mathrm{ft}$ upstream from the dam, at seven locations along the Wateree River, and in Sanders Creek at State highway 97. Attempts were made to collect sediment samples at two other locations, $400 \mathrm{ft}$ downstream from the dam and at RM 71.1, but were abandoned because the river bed was composed mainly of rocks at these locations. The samples collected in Lake Wateree, at Wateree River station 02148306 (RM 23.8), and in Sanders Creek at State highway 97 were tested for SOD. The other five samples collected at RM's 69.5, 68.4, 67.0, 63.4 , and 60.8 were not tested because the bed materials were coarse sand, gravel, or rock-materials that typically do not have significant SOD. The bed materials in the river sample and the Sanders Creek sample consisted of medium-to-coarse sand and fine sand, respectively.

The sediment samples were analyzed for biological and chemical SOD based on procedures documented by Wang (1979). The fractionization of the biological and chemical SOD was accomplished by treating the samples with phenol, a toxicant used to suppress the biological SOD. The SOD of the untreated lake sample was 6.5 milligrams per liter per gram of dry sediment $([\mathrm{mg} / \mathrm{L}] / \mathrm{g})$, expressed in DO consumption in 1 hour. From the treated lake sample, it was determined that the chemical SOD was $5.3(\mathrm{mg} / \mathrm{L}) / \mathrm{g}$. Therefore, the chemical and biological SOD for the lake sediment was calculated to be 82 and 18 percent, respectively. It should be noted that this laboratory method of determining SOD gives much higher values than an in situ method. This is because a sample in the laboratory is well mixed, a condition unlikely to occur in the field. Therefore, the laboratory SOD reflects a maximum value that is best used for comparative and quantitative characterization of sediment samples. The other two samples that were analyzed (RM 23.8 and Sanders Creek) had negligible amounts of SOD. On the basis of the SOD results, it was concluded that the DO depletion occurring in the upper Wateree River was not caused by SOD.

Four tributaries with significant streamflow that enter the Wateree River between Lake Wateree Dam and U.S. 1 are Grannies Quarter, Sawneys, Sanders, and Twenty-Five Mile Creeks. During some of the longitudinal profiles, DO concentrations were measured in these tributaries. The DO concentrations generally were higher in the tributaries than in the river. Results indicated that the tributaries did not have an adverse effect on the DO concentrations in the river.

On June 27, 1996, samples were collected at nine locations on the Wateree River from RM 70.0 to RM 23.8 and analyzed for 5-day $\mathrm{BOD}\left(\mathrm{BOD}_{5}\right)$ and 30-day $\mathrm{BOD}\left(\mathrm{BOD}_{30}\right)$ concentrations. The $\mathrm{BOD}_{30}$ samples were treated with a nitrification inhibitor in order to measure carbonaceous BOD. The $\mathrm{BOD}_{5}$ concentrations for each of the samples were less than 1 $\mathrm{mg} / \mathrm{L}$. The $\mathrm{BOD}_{30}$ concentrations ranged from 1 to $3 \mathrm{mg} / \mathrm{L}$. Additional samples also were collected on August 16 and September 10 and 11, 1996, and analyzed for $\mathrm{BOD}_{5}$. Once again the results indicated 
that no significant $\mathrm{BOD}_{5}$ concentrations were detected in the upper reach of the Wateree River. It was concluded that the depletion of DO concentrations was not caused by BOD decay.

\section{DATA COLLECTION AND ANALYSIS}

Data collected for this study were (1) continuous water level (stage), DO concentration, and water temperature at three USGS gaging stations;

(2) DO concentration and water temperature only at one gaging station; (3) streamflow data for five tributaries; (4) cross-sectional data of the Wateree River; (5) longitudinal DO concentration profile data; (6) stream reaeration and time-of-travel data; (7) synoptic nutrient and metals data at 17 locations; (8) meteorologic data; and (9) effluent concentrations and discharge data from the municipal and industrial facilities. Permitted wastewater-discharge data from treatment plants and monthly water-quality monitoring data were provided by the effluent dischargers and the SCDHEC.

\section{Water-Level and Streamflow Data}

Water-level data were collected at USGS stations 02148000 and 02148315 by using data-collection platforms (DCP's) at stilling-well gages, and at station 02148306 (Wateree River near Wedgefield, S.C.) by using a DCP with an acubar pressure gage (fig. 3). Data were collected at 15-minute intervals at station 02148000 and at 30 -minute intervals at stations 02148315 and 02148306 . Each station datum was determined by using standard differential leveling techniques. Stage data have been collected at stations 02148000 and 02148315 since 1929 and 1968 , respectively, and from June 1996 through September 1997 at station 02148306 . A series of streamflow measurements at selected stages has been made at these stations and used to develop stage-streamflow relations (rating curves). Because of an extensive swamp east of the river, the rating curve for station 02148315 is applicable only for flows less than $10,000 \mathrm{ft}^{3} / \mathrm{s}$, below which flows are confined to the main channel. These relations were used in the calibration and validation of the streamflow model.

In addition, rating curves were developed for five tributaries in the upper Wateree River. Stage data were recorded simultaneously with nutrient sampling at the five major tributaries: Grannies Quarter, Sawneys, Sanders, Twenty-Five Mile, and Big Pine Tree Creeks. The stage data were used to compute streamflow based on rating curves established by the USGS for this study. The USGS streamflow and stage unit-value data were stored in a time-dependent data base and in the USGS automated data processing system (ADAPS). The locations of the water-level gages and tributary streamflow measurement sites are shown in figure 3 and listed in table 7.

Table 7. Streamflow or water-level gaging stations and(or) water-quality monitoring stations on the Wateree River, S.C.

[TD, water level from tape down; T, temperature; DO, dissolved oxygen; SC, specific conductance; WL, continuous water level]

\begin{tabular}{llll}
\hline $\begin{array}{c}\text { Station no. } \\
\text { (fig. 3) }\end{array}$ & \multicolumn{1}{c}{ Station name } & $\begin{array}{c}\text { River } \\
\text { mile }\end{array}$ & $\begin{array}{c}\text { Parameters } \\
\text { monitored }\end{array}$ \\
\hline $02147810^{\mathrm{a}}$ & Grannies Quarter Creek at S.C. 97 near Camden, S.C. & $73.1^{\mathrm{b}}$ & TD \\
$02147820^{\mathrm{a}}$ & Sawneys Creek at Road S-37 near Camden, S.C. & $72.7^{\mathrm{b}}$ & TD \\
$021479107^{\mathrm{a}}$ & Sanders Creek at S.C. 97 near Camden, S.C. & $71.7^{\mathrm{b}}$ & TD \\
$02147930^{\mathrm{c}}$ & Wateree River near Lugoff, S.C. & 67.4 & T, DO, SC \\
$02147990^{\mathrm{a}}$ & Twenty-Five Mile Creek at Road S-5 near Lugoff, S.C. & $67.0^{\mathrm{b}}$ & TD \\
$02148000^{\mathrm{d}}$ & Wateree River at U.S. 1 near Camden, S.C. & 66.6 & WL, T, DO, SC \\
$02148056^{\mathrm{a}}$ & Big Pine Tree Creek at Interstate 20 near Camden, S.C. & $62.6^{\mathrm{b}}$ TD \\
$02148306^{\mathrm{d}}$ & Wateree River at U.S. 378 near Wedgefield, S.C. & 23.8 & WL, T, DO, SC \\
$02148315^{\mathrm{d}}$ & Wateree River below Eastover, S.C. & 10.1 & WL, T, DO, SC \\
\hline
\end{tabular}

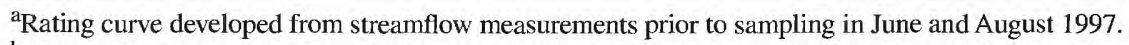

${ }^{b}$ River mile represents the location of the confluence of the tributary with the Wateree River.

${ }^{\mathrm{c} C}$ Continuous water-quality monitoring station from June to September 1997.

${ }^{\mathrm{d} C}$ Continuous streamflow gaging and water-quality monitoring station during study. 


\section{Channel-Geometry Data}

Channel-geometry data were obtained from field surveys during a previous study (Hurley, 1991). Streambed profiles were surveyed at or near gaging stations, streamflow measurement sites, water-quality sampling sites, and selected locations at channel transitions (for example, contractions or expansions). The channel part of each cross section was obtained from fathometer traces, and the flood-plain widths were estimated by using stadia readings from standard levels and by reviewing topographic maps. A common datum was established for all cross sections by inspection of level notes, water-surface elevations, and USGS topographic maps. The channel-geometry data were converted into a BRANCH model usable format by the USGS Channel Geometry Analysis Program (Regan and Schaffranek, 1985).

\section{Longitudinal Profiles of Dissolved- Oxygen Concentrations}

Nine longitudinal profiles of DO concentrations were measured in the Wateree River during the spring and summer of 1996, as discussed previously. The data were collected by using a digital DO meter that was calibrated at the beginning of each profile. During the initial profiles, measurements were taken in the upper, middle, and(or) lower parts of the water column to evaluate vertical differences in DO concentrations. No significant differences in DO concentrations were found. In addition, a few of the sites were measured at several lateral locations. At these locations, DO concentrations ranged from 2 to 15 percent from the mean. Therefore, the data suggest that the Wateree River is a well-mixed stream with respect to DO concentrations. Subsequently, longitudinal profile measurements typically were taken from the center of the stream in the upper to middle part of the water column.

\section{Synoptic Water-Quality Data}

Water-quality data that were used to calibrate and validate the BLTM were collected during two synoptic sampling periods when water-quality samples were collected at 1 lake site, 11 river sites, 5 tributary sites, and 4 wastewater-discharge sites (fig. 9; table 8). Because the flows were held steady during the sampling periods and because previous time-of-travel studies had been made on the Wateree River, a Lagrangian sampling scheme was designed in an effort to reduce data-collection cost (Feaster, 1998). Prior to the sampling, a preliminary transport model was calibrated using the previous time-of-travel data and assumed steady flows. In a Lagrangian model, the streamflow is separated into parcels. The model tracks the parcels as they move through the riverine system.

Using the preliminary transport model, a sampling schedule was designed to track three water parcels completely through the study reach, track six water parcels partially through the study reach, and then collect additional samples to document changing conditions at the sampling sites (fig. 10). Consequently, each site was sampled approximately 4 to 5 times per day. An initial sample was collected at each site to record background water-quality conditions. The collection times for the background samples were chosen so that the first sample at all sites would have been collected by 0600 hours Eastern Standard Time (EST), which was the beginning time for the first parcel. Additional samples were collected every 4 to 6 hours to obtain a time series of data. The beginning times for the water parcels that were tracked through the system were 0600,1200 , and 1800 hours EST for the June 23-25, 1997, sampling period and 0600, 1100 , and 1700 hours EST for the August 11-13, 1997, sampling period. These times were chosen (1) to allow sufficient time for the sampling teams to collect data at each station and prepare to sample the next parcel, (2) to record the influence of diurnal fluctuations, and (3) to minimize late-night sampling for safety concerns. Because the peak travel times were based on some simplifying assumptions and to aid in logistics, all sample-collection times were rounded to the nearest half hour. In addition, 24-hour composite samples were collected from each of the dischargers during the 3-day periods.

Tributary sample times were chosen to obtain a time series of data for each day without conflicting with in-river sample collections. The tributary sampling was focused in the upper part of the Wateree River (upstream from station 02148000 ) because of the DO dynamics of that reach. Of the five tributaries sampled, only Big Pine Tree Creek was located downstream from station 02148000 . As previously mentioned, after the synoptic sampling in the summer of 1997, the upper boundary of the flow and transport models was moved to station 02147930 (RM 67.4). Tributaries included in 


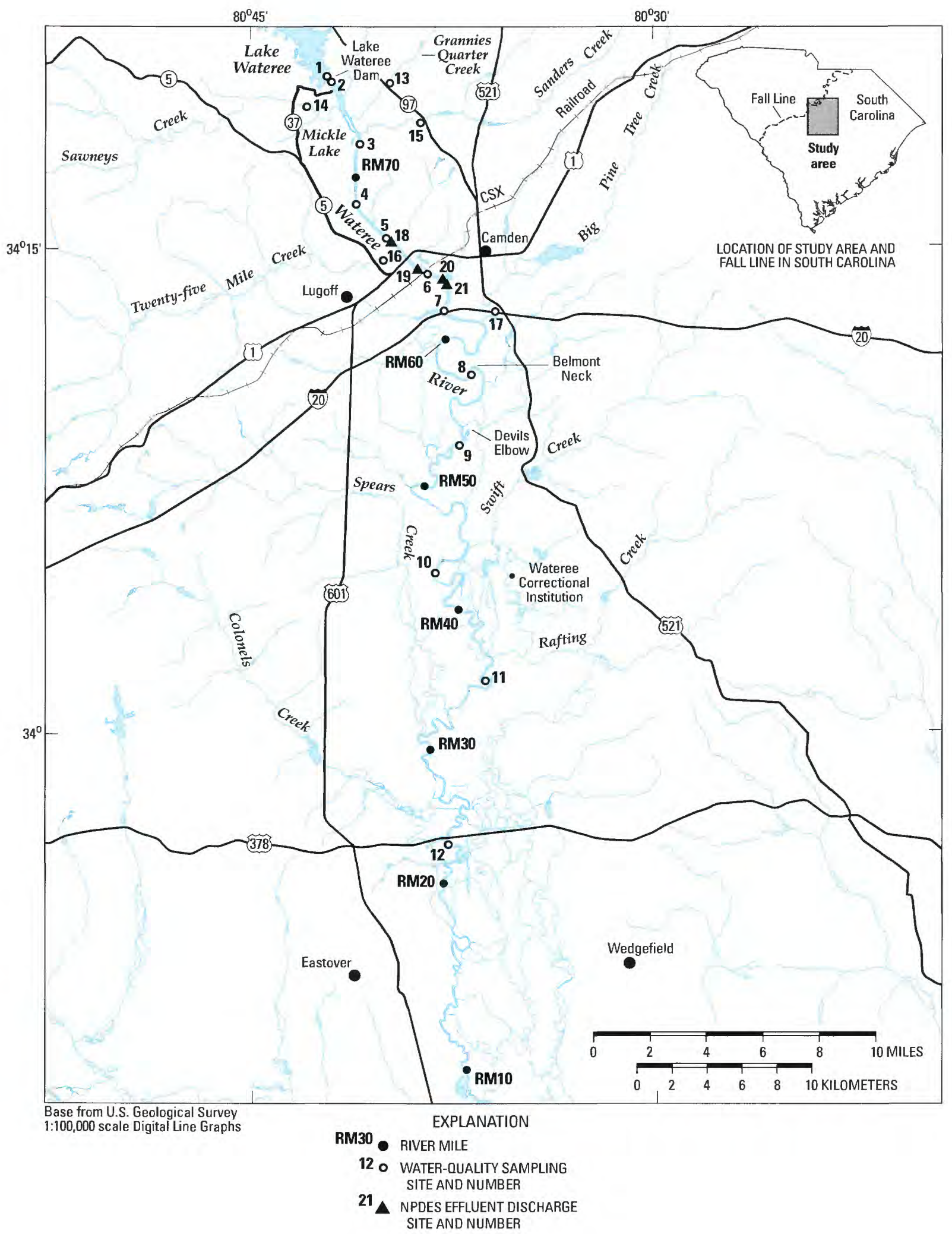

Figure 9. River miles, in-river and tributary water-quality sampling sites, and National Pollutant Discharge Elimination System (NPDES) effluent discharge sites included in the Branched Lagrangian Transport Model (BLTM) for the Wateree River, S.C. 
Table 8. Water-quality sampling locations in the main stem, selected tributaries, and at point-source discharges to the Wateree River, S.C., June 23-25 and August 11-13, 1997

\begin{tabular}{|c|c|c|}
\hline $\begin{array}{c}\text { Site } \\
\text { number } \\
\text { (fig. 9) }\end{array}$ & Description & $\begin{array}{c}\text { Location, } \\
\text { river mile } \\
\text { (fig. 9) }\end{array}$ \\
\hline \multicolumn{3}{|c|}{ Lake and in-river stations } \\
\hline 1 & Bottom of Lake Wateree at approximately $150 \mathrm{ft}$ upstream from the dam & 73.8 \\
\hline 2 & Lake Wateree tailrace & 73.7 \\
\hline 3 & Downstream from island near Mickle Lake & 71.1 \\
\hline 4 & Powerline right-of-way & 69.5 \\
\hline 5 & At station 02147930 , about $1,600 \mathrm{ft}$ upstream from site 18 & 67.4 \\
\hline 6 & At upstream end of island below railway trestle & 65.6 \\
\hline 7 & Near Interstate 20 bridge & 63.9 \\
\hline 8 & Near Belmont Neck & 57.3 \\
\hline 9 & Downstream from Devils Elbow & 52.5 \\
\hline 10 & Near Wateree Correctional Institute & 43.8 \\
\hline 11 & Downstream from Rafting Creek & 35.8 \\
\hline 12 & At station 02148306 & 23.8 \\
\hline \multicolumn{3}{|c|}{ Tributary stations } \\
\hline 13 & Grannies Quarter Creek at S.C. 97 & $73.1^{\mathrm{a}}$ \\
\hline 14 & Sawneys Creek at Road S-37 & $72.7^{\mathrm{a}}$ \\
\hline 15 & Sanders Creek at S.C. 97 & $71.7^{\mathrm{a}}$ \\
\hline 16 & Twenty-Five Mile Creek at Road S-5 & $67.0^{\mathrm{a}}$ \\
\hline 17 & Big Pine Tree Creek at Interstate 20 & $62.6^{\mathrm{a}}$ \\
\hline \multicolumn{3}{|c|}{$\begin{array}{c}\text { Point-source discharges } \\
\text { (24-hour composite samples collected by dischargers) }\end{array}$} \\
\hline 18 & Lugoff Wastewater-Treatment Plant & $67.1^{\mathrm{a}}$ \\
\hline 19 & DuPont Fibers & $66.1^{\mathrm{a}}$ \\
\hline 20 & Camden Sewage Treatment Plant & $65.0^{\mathrm{a}}$ \\
\hline 21 & Hardwicke Chemical & $64.8^{\mathrm{a}}$ \\
\hline
\end{tabular}

${ }^{a}$ The tributary stations and point-source discharge locations indicate the confluence with the Wateree River and the location of the effluent pipe, respectively, and not the actual sample location.

the final model were Big Pine Tree Creek (RM 62.6), Swift Creek (RM 43.4), Rafting Creek (RM 36.9), and Spears Creek (RM 30.8). Of these tributaries, only Big Pine Tree Creek was sampled for water-quality constituents. For the other tributaries, water-quality data from the closest upstream in-river station were used for the water-quality boundary data.

Steady flows of approximately 2,700 and $2,000 \mathrm{ft}^{3} / \mathrm{s}$, respectively, were released from Lake Wateree Dam during June 23-25 and August 11-13, 1997. Field measurements of $\mathrm{pH}$, water temperature, and DO concentrations were made at the time of waterquality sampling. Water-quality samples were analyzed by a private laboratory, certified by the SCDHEC, for TKN, total ammonia nitrogen, nitrite plus nitrate nitrogen, total phosphorus, orthophosphorus, chlorophyll $a$, total and dissolved iron, total and dissolved manganese, $\mathrm{BOD}_{5}$, and ultimate carbonaceous biochemical oxygen demand $\left(\mathrm{CBOD}_{\mathrm{u}}\right)$.

The results of iron and manganese analyses were not included in the BLTM, but iron and manganese concentrations were measured in an effort to understand the potential influences on the decrease in DO concentrations in the upper reach. Dortch and others (1992) have extensively studied the water quality downstream from reservoirs. Their work focused on reservoir releases that are often low in DO concentrations and high in reduced substances, such as iron, manganese, and sulfide. Once this anoxic water is released into a tailrace, oxidation of the reduced substances begins, reducing the available DO. Locations of the sampling sites are shown in figure 9, and station information is listed in table 8 . 

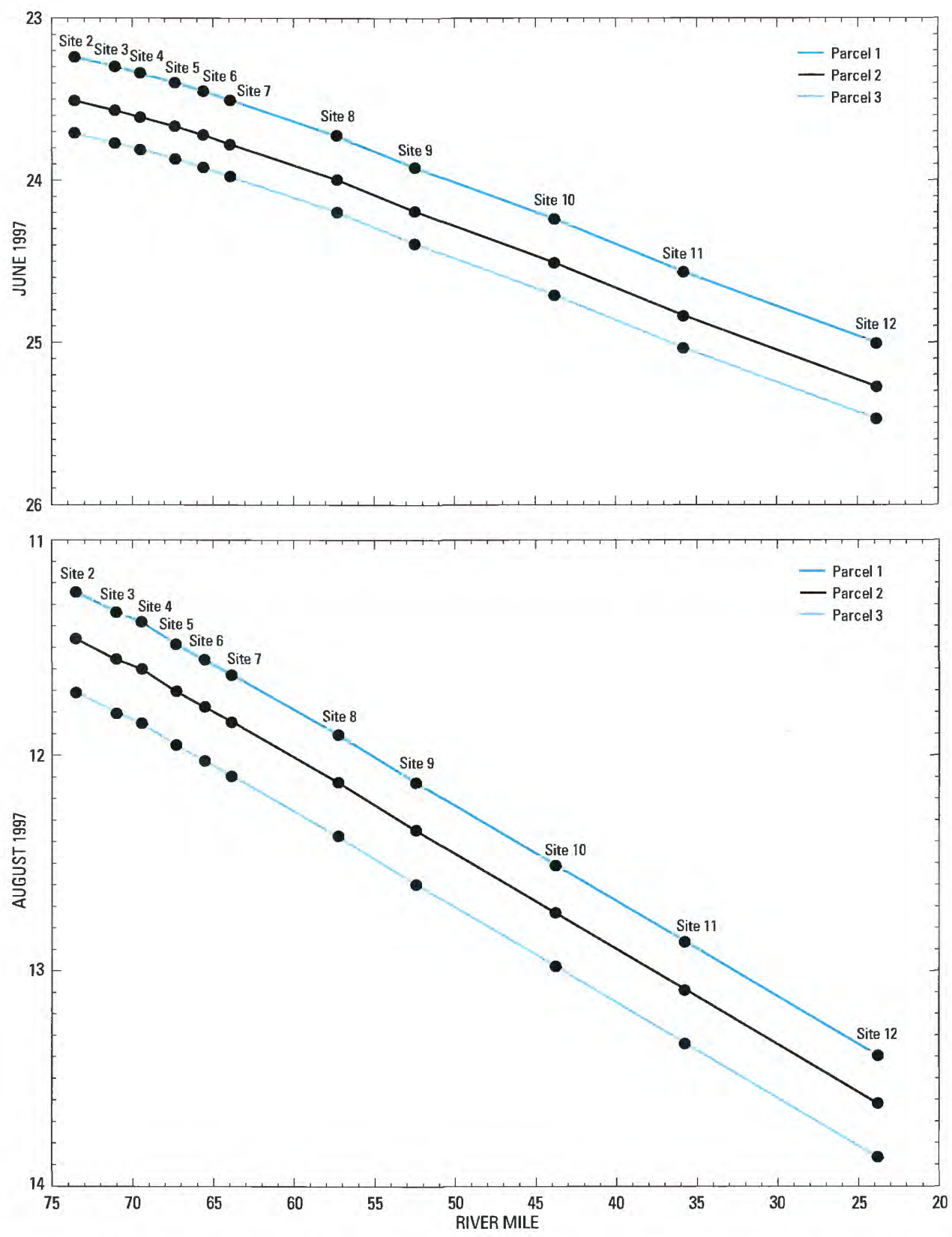

Figure 10. Three water parcels tracked from site 2 to site 12 based on travel time of peak dye concentrations, and water-quality sample collection times for the Wateree River, S.C., June 23-25 and August 11-13, 1997.

Dortch and others (1992) noted that the general consensus from the literature is that oxidation kinetics of sulfide in natural waters is very complex and poorly understood. At a pH of about 7.0, sulfide concentrations are about half hydrogen sulfide and half bisulfide ion. Hydrogen sulfide often is detectable by an odor similar to rotten eggs. Consequently, because no sulfide odors had been detected in the upper Wateree River and because of the complexity of the kinetics involved in sulfide oxidation, it was decided that sulfides would not be sampled during the synoptic studies. (However, in August 1999 subsequent to the study, strong hydrogen sulfide odors were present during a field visit to the Wateree Dam. Samples collected from the forebay on the same day verified the presence of hydrogen sulfide. Therefore, it is reasonable to surmise that on some occasions sulfides also are influencing the water quality in the upper Wateree River). 
The DO concentrations measured during the June and August 1997 synoptic samplings for the inriver stations revealed similar patterns as documented by the longitudinal-profile data (figs. 9,11 ). The median DO concentrations in the tailrace were $2.8 \mathrm{mg} / \mathrm{L}$ for June $23-25$ and $2.9 \mathrm{mg} / \mathrm{L}$ for August 11-13, 1997. Downstream from the shoals, which extend from approximately RM 73.5 to RM 71.1, the median DO concentrations at site 3 (RM 71.1) were $5.0 \mathrm{mg} / \mathrm{L}$ in June and $5.1 \mathrm{mg} / \mathrm{L}$ in August. The lowest median DO concentrations were 4.1 and $4.4 \mathrm{mg} / \mathrm{L}$ for June and August, respectively, and occurred at site 4 (RM 69.5). The first point-source discharge entered the

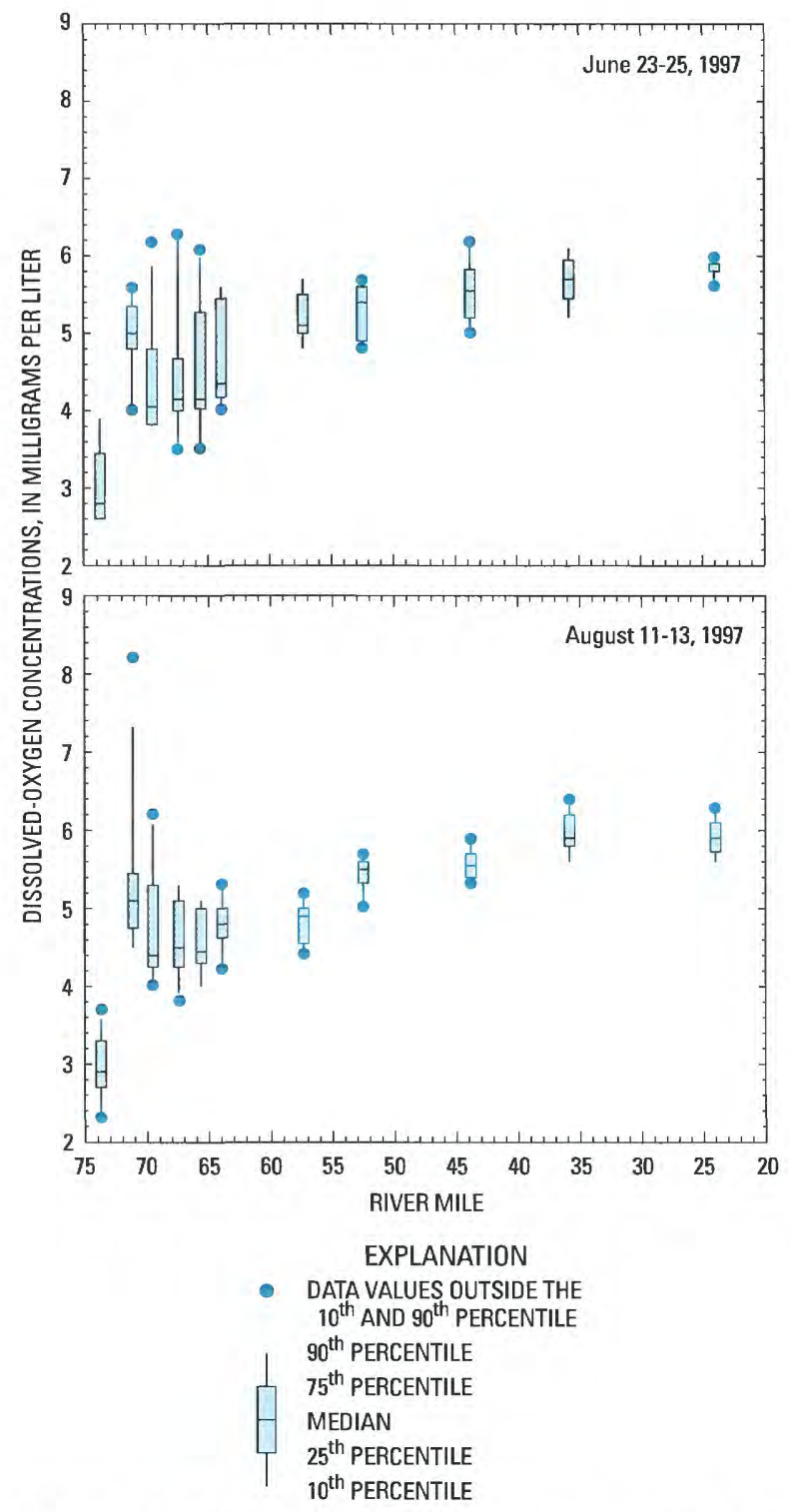

Figure 11. Measured dissolved-oxygen concentrations at 11 locations on the Wateree River, S.C., June 23-25 and August 11-13, 1997. river downstream from site 4 at RM 67.1. Below site 4, the median DO concentrations continued to increase throughout the study reach.

No significant variations occurred in the median concentrations of $\mathrm{BOD}_{5}$ throughout the study reach of the river. During the June sampling, the median $\mathrm{BOD}_{5}$ concentrations ranged from 1.6 to $3.8 \mathrm{mg} / \mathrm{L}$ (fig. 12), and the median $\mathrm{BOD}_{5}$ concentrations in August ranged from 1.4 to $3.8 \mathrm{mg} / \mathrm{L}$ (fig. 13).

The median chlorophyll $a$ concentrations during the June sampling ranged from below the detection limit of 0.075 micrograms per liter $(\mu \mathrm{g} / \mathrm{L})$ to $1.6 \mu \mathrm{g} / \mathrm{L}$ (fig. 12). The median chlorophyll $a$ concentrations during the August sampling were all below the detection limit (fig. 13), which suggests, as previously mentioned, that algae have no significant influence on DO concentrations in the Wateree River.

Plots of the water-quality constituents indicate that upon entering the river from the lake, some of the nutrient and metal concentrations are quickly oxidized (figs. 12, 13). The biological conversion of ammonia, iron, and manganese can consume significant amounts of DO: $1.0 \mathrm{mg} / \mathrm{L}$ of oxygen each per $0.22 \mathrm{mg} / \mathrm{L}$ of ammonia nitrogen, $1 \mathrm{mg} / \mathrm{L}$ of iron, and $3.45 \mathrm{mg} / \mathrm{L}$ of manganese (Dortch and others, 1992). In the nitrogen cycle, ammonia nitrogen is converted to nitrate. Consequently, if ammonia is being reduced, nitrate concentrations would be expected to increase. A decrease in median ammonia concentrations in the upper Wateree River can be seen in the August plots and are more pronounced than in the June plots for the 1997 sampling period (figs. 12, 13). In addition, the plots of median nitrite plus nitrate concentrations show a much more defined increase. The plots of median concentrations of manganese also show a decreasing trend in the upper Wateree River for both June and August. Consequently, based on the stoichiometry of these reduced constituents and the trends noted in figures 12 and 13, the data suggest that the transformations of these reduced constituents from the lake can account for much of the decrease in DO concentrations in the upper reach.

These data support the theory, developed during the early stages of this study, that the quality of the water discharged from Lake Wateree has a significant effect on the DO patterns in the upper Wateree River. In addition, the proliferation of macrophytes in the shoal area also suggests an abundance of readily available nutrients from the lake. However, further investigations 

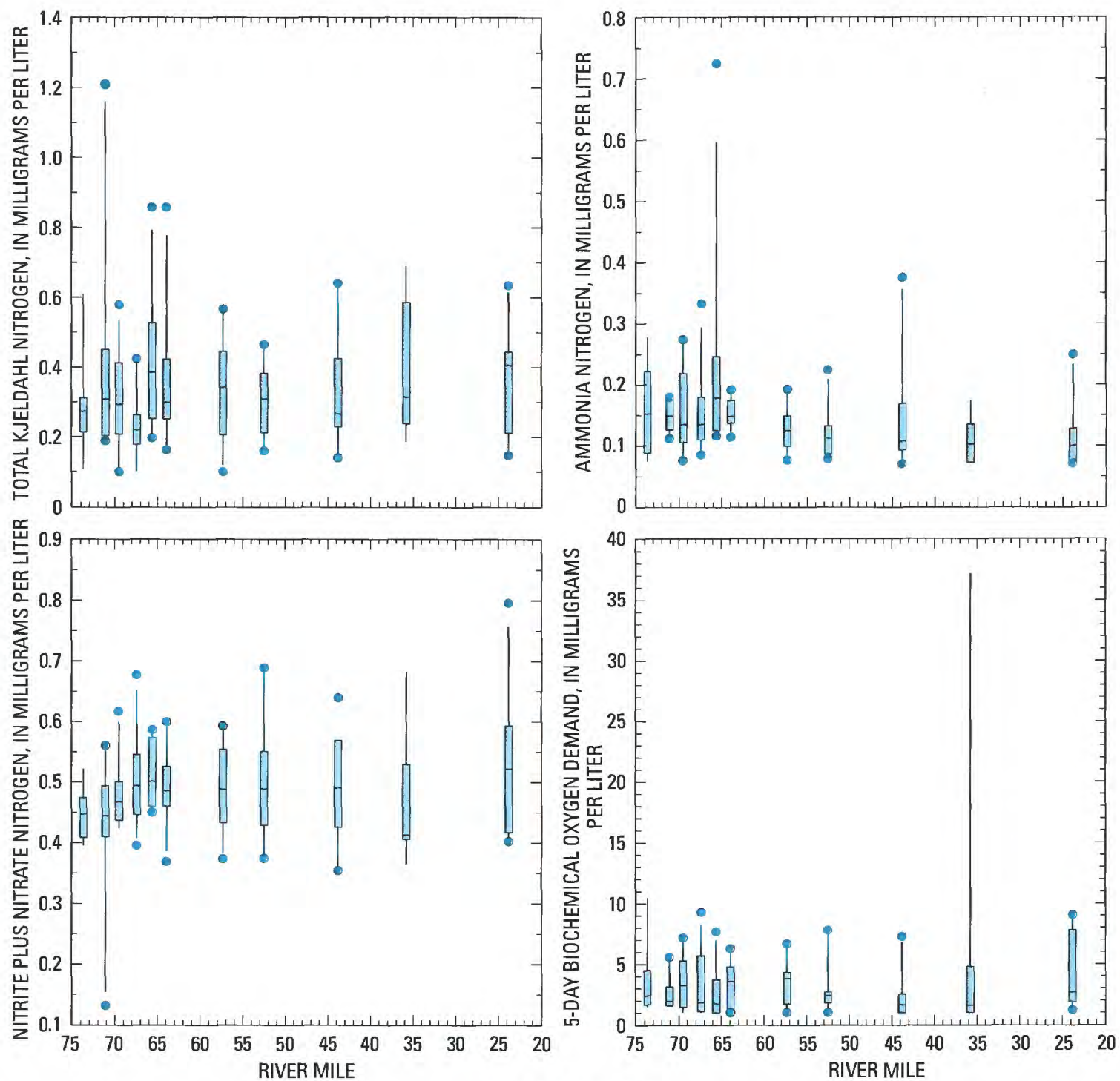

EXPLANATION

- datA VAlUES OUTSIDE THE

$10^{\text {th }}$ AND $90^{\text {th }}$ PERCENTILE

$90^{\text {th }}$ PERCENTILE

$75^{\text {th }}$ PERCENTILE

MEDIAN

$25^{\text {th }}$ PERCENTILE

$10^{\text {th }}$ PERCENTILE

Figure 12. Water-quality data collected at 11 locations on the Wateree River, S.C., June 23-25, 1997. 

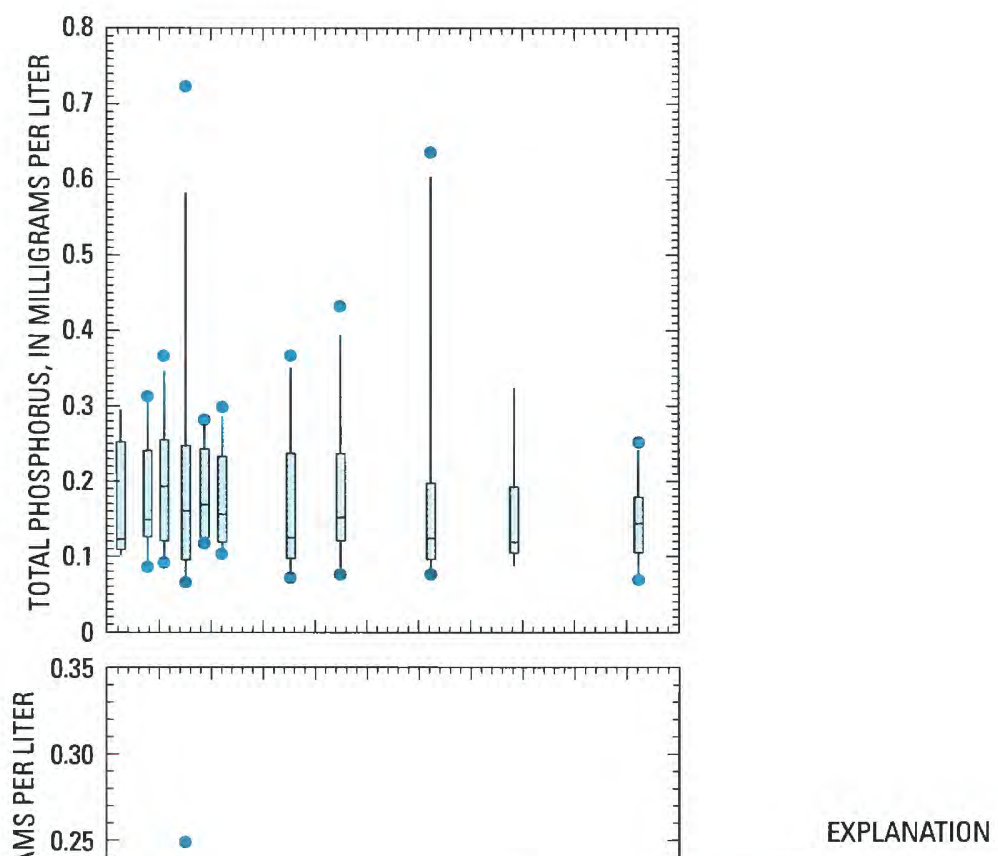

- DATA VALUES DUTSIDE THE $10^{\text {th }}$ AND $90^{\text {th }}$ PERCENTILE $90^{\text {th }}$ PERCENTILE

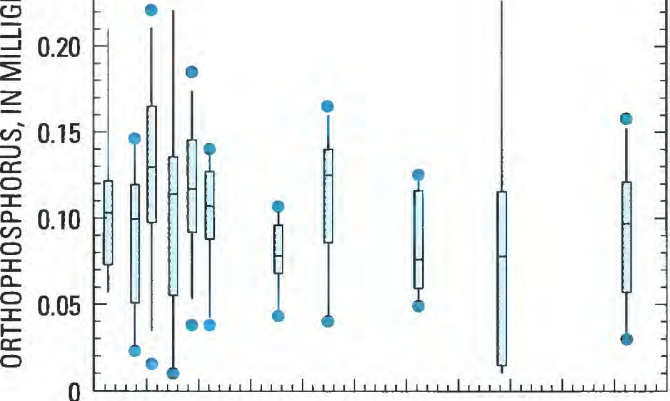

$75^{\text {th }}$ PERCENTILE

MEDIAN $25^{\text {th }}$ PERCENTILE $10^{\text {th }}$ PERCENTILE

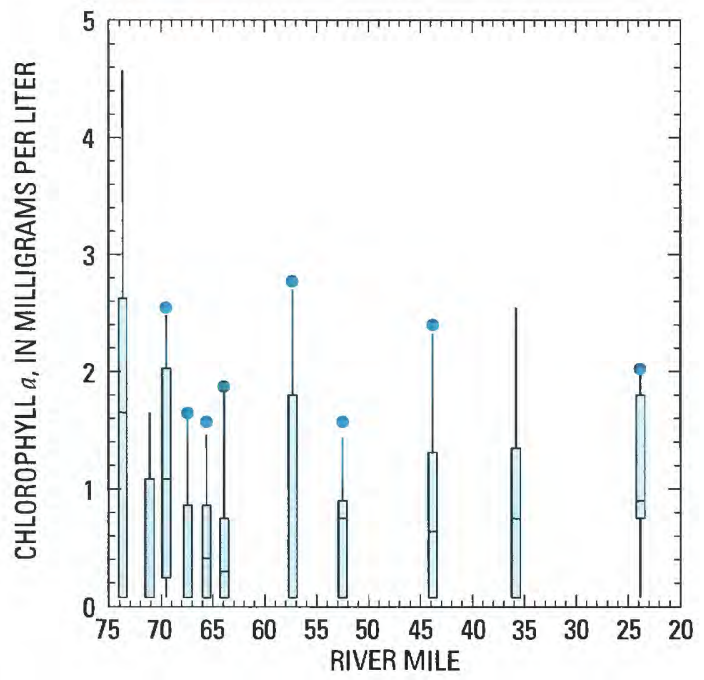

Figure 12. (Continued) Water-quality data collected at 11 locations on the Wateree River, S.C., June 23-25, 1997. 

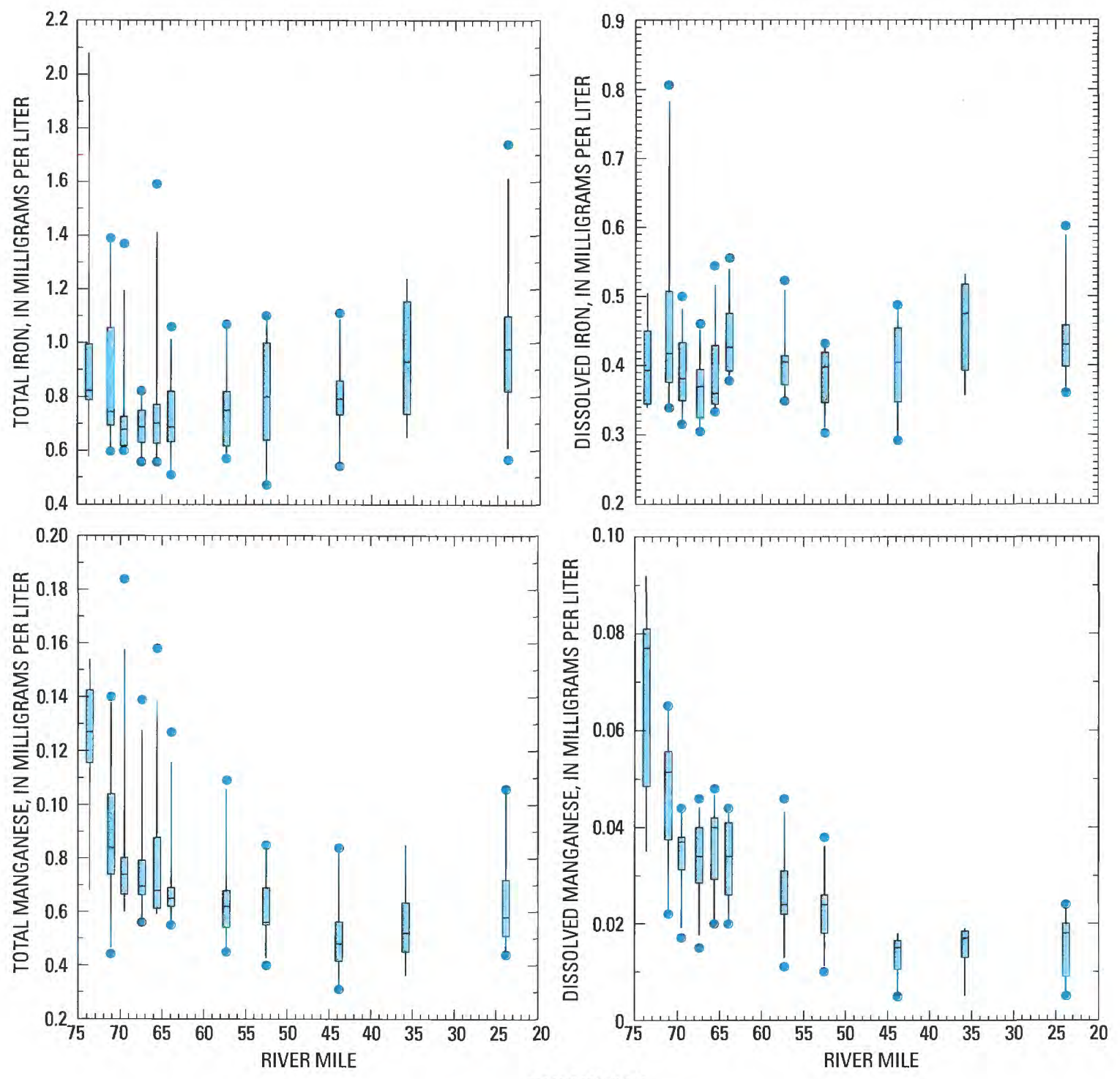

EXPLANATION

- DATA VALUES OUTSIDE THE

$10^{\text {th }}$ AND $90^{\text {th }}$ PERCENTILE

$90^{\text {th }}$ PERCENTILE

$75^{\text {th }}$ PERCENTILE

MEDIAN

$25^{\text {th }}$ PERCENTILE

$10^{\text {th }}$ PERCENTILE

Figure 12. (Continued) Water-quality data collected at 11 locations on the Wateree River, S.C., June 23-25, 1997. 

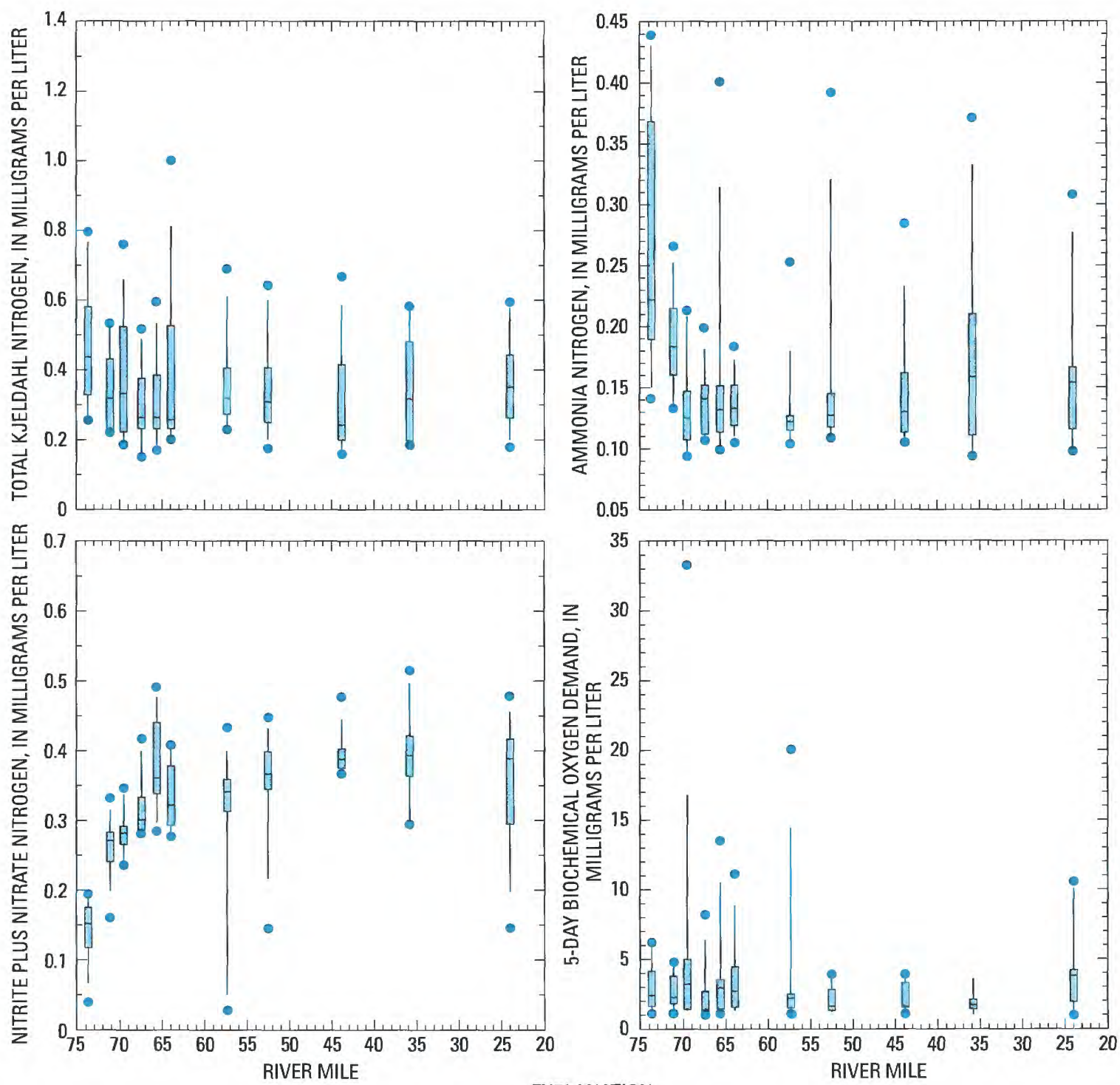

EXPLANATION

- DATA VALUES OUTSIDE THE
$10^{\text {th }}$ AND $90^{\text {th }}$ PERCENTILE

$90^{\text {th }}$ PERCENTILE

$75^{\text {th }}$ PERCENTILE

MEDIAN

$25^{\text {th }}$ PERCENTILE

$10^{\text {th }}$ PERCENTILE

Figure 13. Water-quality data collected at 11 locations on the Wateree River, S.C., August 11-13, 1997. 

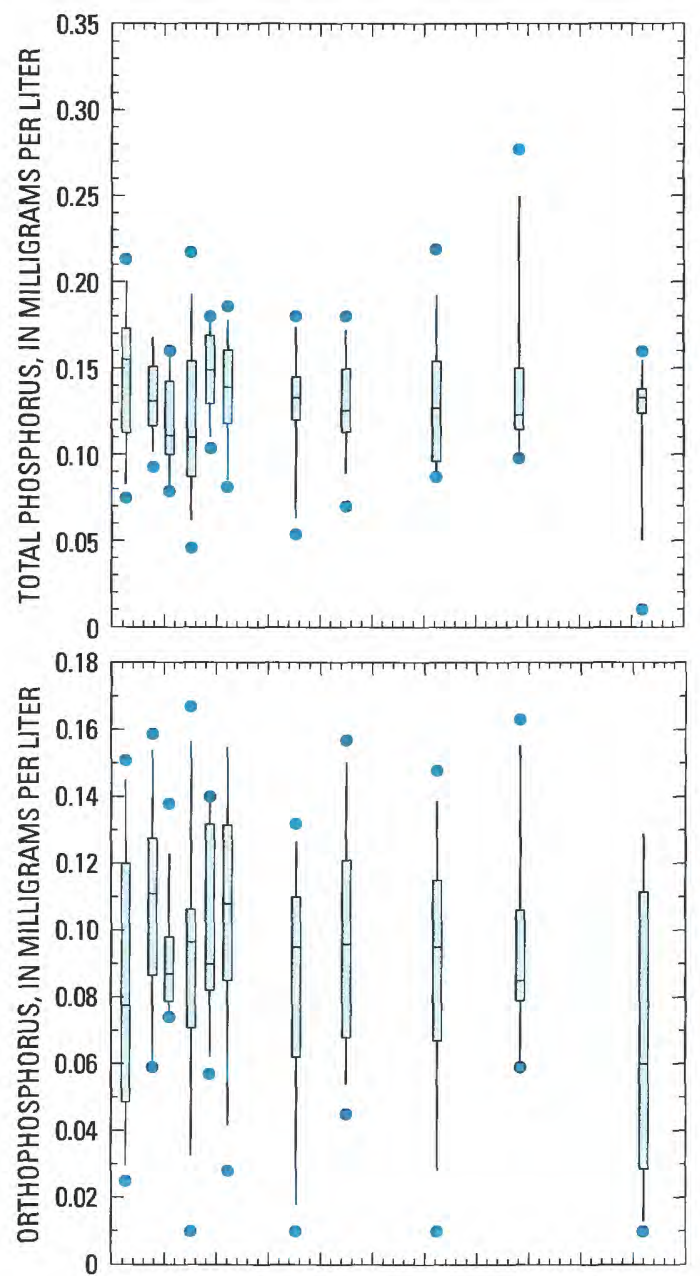

EXPLANATION

- DATA VALUES OUTSIDE THE $10^{\text {th }}$ AND $90^{\text {th }}$ PERCENTILE $90^{\text {th }}$ PERCENTILE

$75^{\text {th }}$ PERCENTILE MEDIAN $25^{\text {th }}$ PERCENTILE $10^{\text {th }}$ PERCENTILE

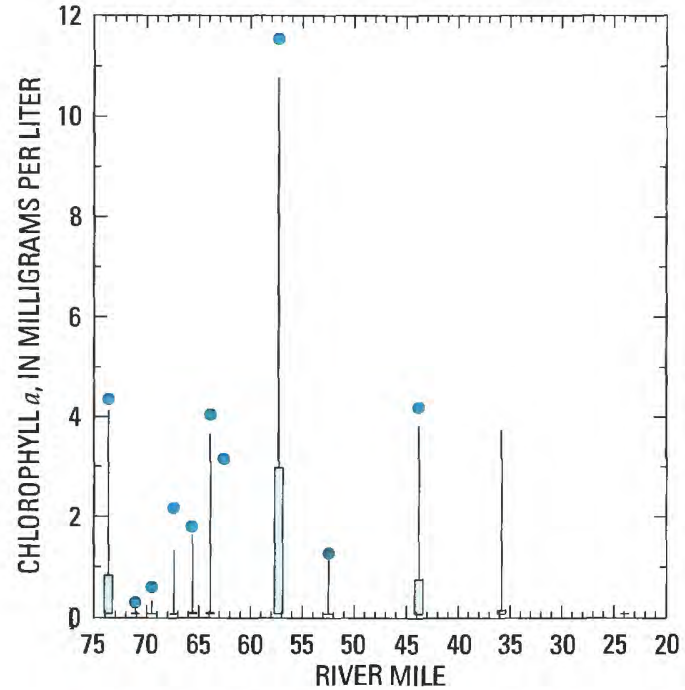

Figure 13. (Continued) Water-quality data collected at 11 locations on the Wateree River, S.C., August 11-13, 1997. 

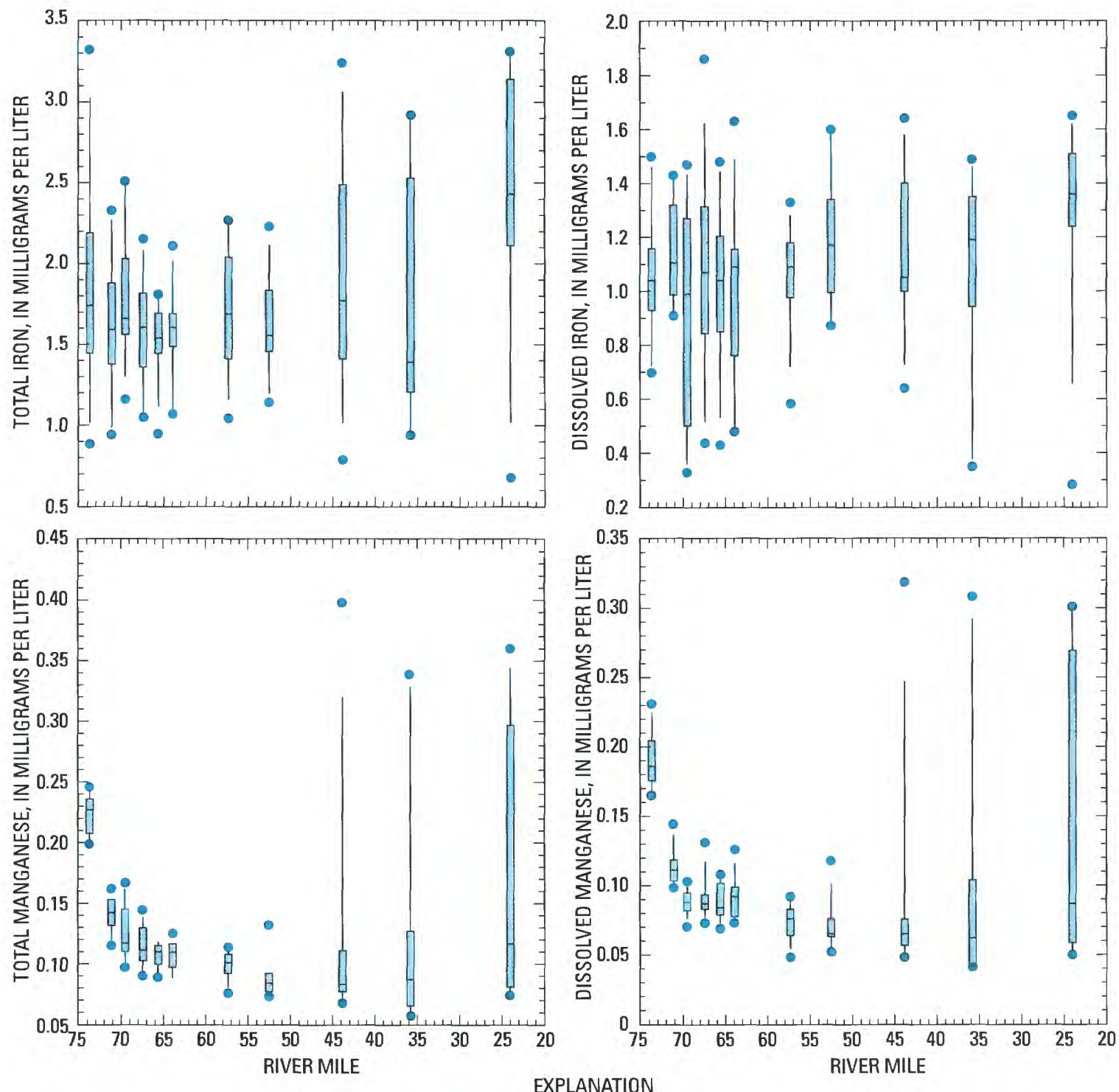

- DATA VALUES OUTSIDE THE

$$
90^{\text {th }} \text { PERCENTILE }
$$

$75^{\text {th }}$ PERCENTILE

MEDIAN

$25^{\text {th }}$ PERCENTILE

$10^{\text {th }}$ PERCENTILE

Figure 13. (Continued) Water-quality data collected at 11 locations on the Wateree River, S.C., August 11-13, 1997. 
are needed to better understand and to better define the water-quality dynamics in the upper Wateree River.

\section{Stream Reaeration and Time-of-Travel Data}

Stream reaeration coefficients were measured by using methods developed by the USGS (Kilpatrick and others, 1989). During the June 1997 sampling phase of the study, the flow from the Wateree Dam was held steady at approximately $2,700 \mathrm{ft}^{3} / \mathrm{s}$. On June 24,1997 , propane gas and a dye tracer were released in the Lake Wateree tailrace near the face of the dam. Dye concentrations were measured at eight locations along a 50-mile reach of the river from the tailrace to USGS station 02148306 (RM 73.5 to RM 23.8) - sites 2, 3, 5, 7, 8, 9, 11, and 12 (table 9; fig. 9). At sites 2, 3, 5, and 7 , streamflow measurements were made, the 16.7-, 50-, and 83.3-percent cumulative discharge points across the channel were flagged, and water samples were collected for dye and propane. The dye provided time-of-travel data and indicated when the gas plateau had been reached. The propane gas was measured at five locations between RM 73.5 and RM 57.3 - sites 2, $3,5,7$, and 8 . Based on preliminary computations, it was assumed that complete mixing would have occurred by site 5 . Because of this assumption and because the dye cloud was estimated to arrive at site 8 after nightfall, the dye clouds at sites $8,9,11$, and 12 were sampled by using an automatic sampler. The sampler intakes were positioned near the center of flow. The propane samples were preserved and shipped to

Table 9. Sample locations for the reaeration and time-of-travel studies on the Wateree River, S.C., June 24-25 and August 11-13, 1997

\begin{tabular}{ccc}
\hline $\begin{array}{c}\text { Site no. } \\
\text { (fig. 9) }\end{array}$ & River mile & Samples collected \\
\hline $2^{\mathrm{a}}$ & 73.5 & Dye and propane \\
$3^{\mathrm{a}}$ & 71.1 & Dye and propane \\
$4^{\mathrm{b}}$ & 69.5 & Dye and propane \\
5 & 67.4 & Dye and propane \\
7 & 63.9 & Dye and propane \\
8 & 57.3 & Dye and propane \\
9 & 52.5 & Dye \\
11 & 35.8 & Dye \\
12 & 23.8 & Dye \\
\hline \multicolumn{3}{c}{${ }^{\mathrm{a}}$ For June 24-25, 1997, sampling phase. } \\
${ }^{\mathrm{b}}$ For August 11-13, 1997, sampling phase.
\end{tabular}

the USGS laboratory in Ocala, Fla., for analysis. No propane was detected in the samples. Upon review of the field procedures, it was concluded that turbulence caused by the hydroelectric turbines (RM 73.8) probably forced the propane out of the water before reaching RM 73.5.

For the reaeration sampling on August 11, 1997, flows from the Wateree Dam were held steady at approximately $2,000 \mathrm{ft}^{3} / \mathrm{s}$, and the release site was moved to RM 71.1. Although this meant that no reaeration coefficient based on actual field data could be calculated for the shoal area, it was concluded that the field data needed to calculate a reaeration coefficient for the Wateree River could be obtained from areas along the river that presented more favorable field conditions. For the August reaeration sampling, the dye tracer was released in the middle of the stream near RM 71.1 and was measured at seven locations between RM 71.1 and RM 23.8-sites 4, $5,7,8,9,11$, and 12 (table 9; fig. 9). Propane-gas samples were collected at four locations between RM 71.1 and RM 57.3 - sites 4, 5, 7, and 8. As during the June 1997 sampling, it was assumed that complete mixing would occur by site 8 , and it was estimated that the dye cloud would arrive at site 8 after nightfall. Consequently, the dye clouds at sites $8,9,11$, and 12 were sampled by using automatic samplers. No dye-cloud data were obtained at site 12 because of automatic sampler failure. Analysis from the USGS laboratory revealed sufficient levels of propane in the samples to allow for the calculation of reaeration coefficients along this reach. In addition, a second time-of-travel study was made on August 13, 1997, between RM 73.5 and RM 69.5 to allow for verification of the transport model through the shoal area.

Field samples of the dye were collected and stored in amber bottles during the sampling in June and August 1997. The samples were brought to the USGS laboratory in Columbia, S.C., stored at a constant temperature, and tested within 1 to 2 weeks of collection. A fluorometer was calibrated to a set of laboratory standards, and dye concentrations were measured.

\section{MODEL SELECTION AND DEVELOPMENT}

The BRANCH model was selected to compute the hydraulic properties of the Wateree River because it can simulate flow in Coastal Plain streams having relatively mild slopes, reversing flows, and backwater conditions. The hydraulic properties computed by the BRANCH model were used for the BLTM. The BLTM is a onedimensional, dynamic transport model that is capable of simulating the fate of water-quality parameters such as 
water temperature, DO, BOD, and nutrients in a network of open channels (Jobson and Schoelhamer, 1987).

The originally proposed domain for the BRANCH model was from the Lake Wateree Dam tailrace to USGS station 02148315 (fig. 3). Streamflow data provided by Duke Energy were to be used as the upstream boundary of the flow model. Duke Energy estimates flows from the dam based on megawatt output. A series of streamflow measurements were made in the tailrace to verify the estimates. The estimated flows ranged from 1 to 13 percent greater than the USGS measured flows with a mean deviation of 4 percent. Station 02148315 was chosen as the downstream boundary of the flow model because continuous hydrologic data have been collected at this site since 1968. Continuous streamflow data have been collected since 1942 at USGS station 02148000 , located approximately $7 \mathrm{mi}$ downstream from the dam.

The originally proposed domain of the BLTM was from the tailrace of Lake Wateree Dam to USGS station 02148306 . During May 1996, station 02148306 was installed on the Wateree River just downstream from U.S. 378 (fig. 3). Water level, DO concentrations, $\mathrm{pH}$, water temperature, and specific conductance were collected at station 02148306 through September 30, 1997. During this period, a stage-streamflow relation was developed so that the stage and flow data collected at the gage could be used for flow model calibration and validation.

During the first phase of the project, longitudinal profiles of the DO concentrations in the river were measured to define the DO concentration curve and locate the $\mathrm{DO}$ concentration sag. The DO concentration sag typically is defined as the lowest DO concentration downstream from a point-source discharge and is assumed to be the result of wastewater assimilation. As previously discussed, the profiles for the Wateree River indicated that the DO concentrations initially were increasing through an approximately 2-mi reach of shoals just downstream from the dam and then decreasing with a sag occurring in the vicinity of the first point-source discharge outfall pipe located at RM 67.1 (fig. 9). Through further investigations and review of the synoptic water-quality data collected during June 23-25 and August 11-13, 1997 (figs. 12, 13), it was concluded that high nutrient levels from Lake Wateree in addition to the river geometry and aquatic plants in the upper reach were the predominant factors causing the increase and sudden decrease in DO concentrations.

The USGS operated a short-term water-quality gage, station 02147930, at RM 67.4 from June 22 through September 30, 1997. A joint review of the water-quality data collected in the summer of 1997 was made by personnel from the KCWSA and the SCDHEC. It was agreed that the upstream boundary of the BLTM would be moved to USGS station 02147930 (RM 67.4) because of the dynamic nature of the upper reach and the time constraints of the cooperator for developing a calibrated model.

The initial flow model calibration for the Wateree River was attempted between the tailrace and USGS station 02148000. The upper and lower boundary data for the BRANCH model were streamflow from the tailrace and water level at station 02148000 , respectively. Beyond the tailrace, the Wateree River channel geometry is a wide, rocky channel approximately $1,200 \mathrm{ft}$ wide with a slope of approximately $2.8 \mathrm{ft} / \mathrm{mi}$. Below the shoal area, the channel narrows to approximately $450 \mathrm{ft}$ with a slope of approximately $0.8 \mathrm{ft} / \mathrm{mi}$. Initial calibration problems occurred near this transition area. It was concluded that the sudden change in channel geometry was acting as a control (R. Schaffranek, U.S. Geological Survey, oral commun., 1998). Consequently, modeling such a transition by using the BRANCH model would probably require the development of a stagestreamflow relation at this transition area.

During attempts to calibrate the preliminary model in the upper reach, a problem with the streamflow data from the dam was discovered. From a statistical analysis of the streamflow data at the tailrace and at USGS station 02148000, the mean streamflow in the tailrace for the calibration period was 3 to 6 percent greater than the streamflow at station 02148000 . Consequently, the flow model did not conserve mass and was storing the excess volume, causing a continuous increase in simulated water level at station 02148000. As a result of this problem and the control problem discussed previously, it was decided that the upstream boundary of the BRANCH model also would be moved to USGS station 02147930.

As previously mentioned, continuous water-quality data were collected at station 02147930 during the summer of 1997. No water-level data were available at this location. Station 02147930 is located 0.9 mi upstream from USGS station 02148000 . It was decided that the water-level and streamflow data at 
station 02148000 would be used at station 02147930 . This was considered acceptable because the distance between the stations is relatively short, the channel geometry is fairly uniform in this reach, and significant historical flow records are available for station 02148000 . An additional cross section was surveyed at USGS station 02147930 and included in the geometry file for the BRANCH model. Water-surface elevations were measured at station 02147930 at selected intervals during the cross-section survey. The measured water-surface elevations were compared with water-level readings collected at USGS station 02148000 at the same time to determine a datum correction for shifting water-level elevations at station 02148000 upstream to station 02147930 .

A statistical analysis was made to determine the lag time between station 02147930 and 02148000 . Water-level and streamflow data were extracted from the BRANCH model at specified branches and cross sections. The lag time between station 02148000 and the next downstream cross section in the BRANCH model was determined by computing correlation coefficients for several lag times. The lag time with the highest correlation coefficient was selected. The distance between the cross sections was then used to estimate a lag time per mile. The lag time between stations 02148000 and 02147930 was determined by multiplying the distance between the stations by the lag time per mile. The analysis indicated no significant lag time during the June 1997 calibration period. A lag time of 38 minutes was computed for the August 1997 validation period. Because the lag time between stations 02148000 and 02147930 was relatively short, and for the convenience of model users, it was decided that the streamflow data from station 02148000 would be used at station 02147930 without regard to lag time.

\section{SIMULATION OF STREAMFLOW AND MASS TRANSPORT}

The BRANCH model is a one-dimensional, unsteady-flow computer model for simulation of streamflow in interconnected channels (Schaffrenek and others, 1981). The model solves the onedimensional equations of continuity and motion:

$$
B(\partial Z / \partial t)+(\partial Q / \partial x)-q=0
$$

and

$$
\begin{aligned}
& (\partial Q / \partial t)+\partial\left(\beta Q^{2} / A\right) / \partial x+g A(\partial Z / \partial x) \\
& +\left(g k / A R^{4 / 3}\right) Q|Q|-q u^{\prime} \\
& -\xi B_{c} U_{a}^{2} \cos \alpha=0
\end{aligned}
$$

where

$B$ is the total channel top width, in feet;

$Z$ is the stage, in feet;

$t$ is the time, in seconds;

$Q$ is the discharge, in cubic feet per second;

$x$ is the longitudinal distance along the channel, in feet;

$q$ is the lateral side-channel flow, in cubic feet per second per foot;

$\beta$ is the dimensionless momentum coefficient;

$A$ is the cross-sectional area, in square feet; $g$ is the gravitational acceleration constant, in feet per second per second;

$k$ is a function defining flow resistance;

$R$ is the hydraulic radius, in feet;

$u^{\prime}$ is the $\mathrm{x}$-component of the lateral side-channel flow velocity, in feet per second;

$\xi$ is the dimensionless wind resistance coefficient;

$B_{c}$ is the top width of the conveyance part of the cross section, in feet; and

$U_{a}$ is the wind velocity in feet per second, occurring at an angle $\alpha$ from the positive $\mathrm{x}$-axis.

The flow-resistance function is expressed as $k=(\eta / 1.486)^{2}$, where $\eta$ is a flow-resistance coefficient similar to Manning's $n$.

In the derivation of equations 1 and 2, it is assumed that the flow is essentially homogeneous in density. The channel is assumed to (1) be reasonably straight, (2) have a simple cross-sectional geometry, such as a rectangular or trapezoidal shape, and (3) have a mild and reasonably constant bottom slope. Approximate solutions for the nonlinear partialdifferential, unsteady-flow equations can be obtained by using finite-difference techniques (Schaffranek and others, 1981). A weighted four-point finite-difference approximation is used in the BRANCH model. 
Rivers are presented in the model as a series of cross sections and channel lengths and are defined as segments, junctions, and branches. Channel-geometry data that characterize the conveyance, area, width, and storage capacity at each cross section are input into the model. A segment is defined by an upstream and a downstream cross section and the distance between them. A group of segments that are separated by junctions are called branches. The beginning or ending junction of a branch with no continuing branches is known as an external boundary. Water-level or streamflow data are input at the external boundaries as boundary conditions for the model. All other stages, streamflow, top width, cross-sectional area, storage area, velocity, and Froude number are computed at cross sections. An idealized BRANCH network model schematization is shown in figure 14.

\section{Tributary Hydrograph Development}

The initial BRANCH model calibration from station 02148000 to station 02148315 was made by assuming constant flows at the five major tributaries (Big Pine Tree, Swift, Rafting, Spears, and Colonels Creeks) between those two stations. As previously mentioned, synoptic water-quality data were collected on the Wateree River during June 23-25 and August 11-13, 1997. Because reaeration studies also were made during these dates, steady flows were maintained from the Lake Wateree Dam at approximately $2,700 \mathrm{ft}^{3} / \mathrm{s}$ during the June sampling period and $2,000 \mathrm{ft}^{3} / \mathrm{s}$ during the August sampling period. Based on streamflow records at the USGS stream gages during the steady-flow periods, intervening inflows from point and nonpoint sources were estimated from

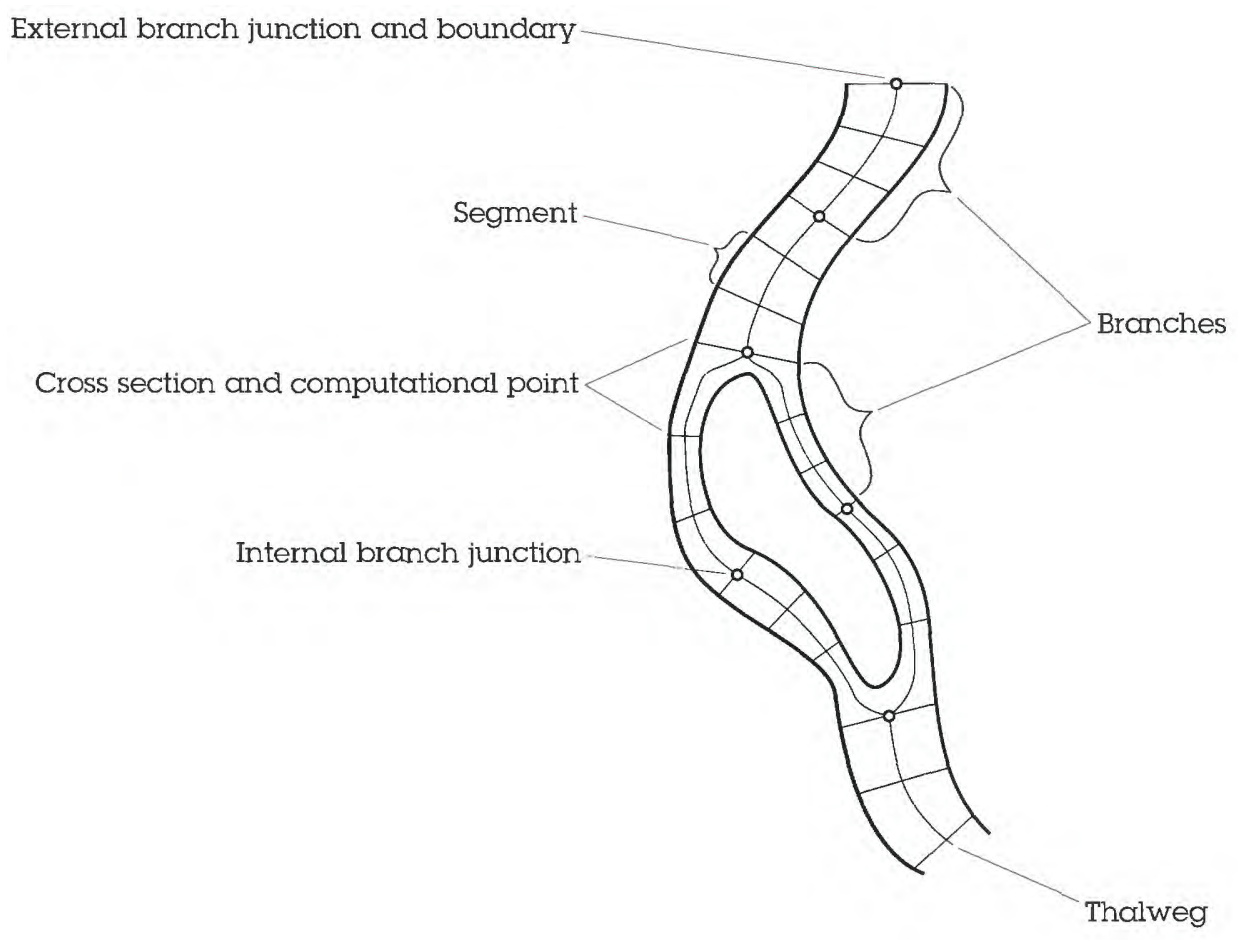

Figure 14. Idealized BRANCH model schematization. 
gage data at stations 02148000,02148306 , and 02148315. A 30-hour steady-flow period was used to estimate the mean steady flow at station 02148000 for the June 1997 sampling period (fig. 15). The plots of streamflow at stations 02148306 and 02148315 indicated that the flow was quasi-steady just prior to returning to unsteady conditions. The inflow between stations 02148000 and 02148306 was $725 \mathrm{ft}^{3} / \mathrm{s}$ and was computed by subtracting the minimum flow during the quasi-steady period at station 02148306 from the minimum flow at station 02148000 . By using the same procedure, the inflow from stations 02148306 to 02148315 was computed as $187 \mathrm{ft}^{3} / \mathrm{s}$.

During the August 1997 sampling period, the streamflow at all three gages reached a steady state. Therefore, the inflow was estimated by taking the difference in the mean flows from the steady-flow period. The inflow from stations 02148000 and

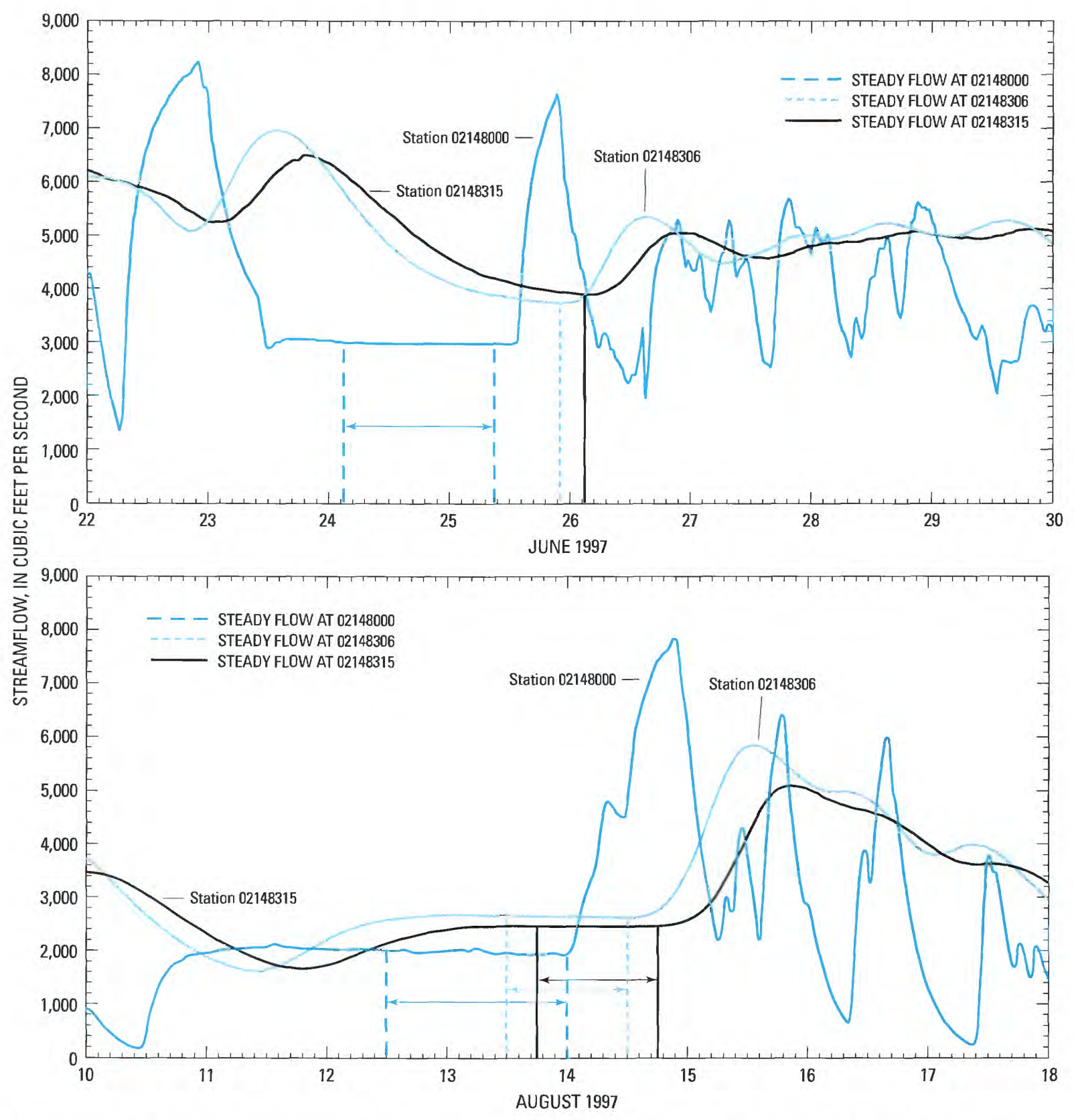

Figure 15. Measured streamflow at USGS stations 02148000, 02148306, and 02148315 used to estimate tributary inflow for the calibration and validation simulations on the Wateree River, S.C., June 22-30 and August 10-18, 1997. 
02148306 was $590 \mathrm{ft}^{3} / \mathrm{s}$, and the inflow from stations 02148306 and 02148315 was estimated to be $-112 \mathrm{ft}^{3} / \mathrm{s}$. The negative inflow calculated between stations 02148306 and 02148315 indicates a decrease in flow between those gages. The flood plain between stations 02148306 and 02148315 is mostly wide, heavily vegetated, and swampy. Consequently, a decrease in flow during the month of August could be explained by high evapotranspiration losses.

The initial flow model calibration accounted for the tributary inflow by prorating the inflow based on the drainage area of the major tributaries and including them as constant flows. The major tributaries between stations 02148000 and 02148315 are Big Pine Tree Creek, Swift Creek, Rafting Creek, Spears Creek, and Colonels Creek (table 10). For the June 1997 sampling period, the tributary flows were estimated by multiplying the inflow between stations 02148000 and 02148315 by the percentage contributed by each tributary to the total intervening drainage area. For the August 1997 sampling period, the inflow between stations 02148000 and 02148306 was used to calculate the tributary inflow. The loss of flow between stations 02148306 and 02148315 was not included. The resulting travel time between these two stations probably is underestimated in the hydrodynamic model, but the implications for transport are minimal

Table 10. Drainage area of tributaries included in the water-quality model for the Wateree River, S.C.

\begin{tabular}{lcc}
\hline \multicolumn{1}{c}{ Tributary } & $\begin{array}{c}\text { Drainage area } \\
\text { (square miles) }\end{array}$ & $\begin{array}{c}\text { Percent of total } \\
\text { tributary } \\
\text { drainage area }\end{array}$ \\
\hline Big Pine Tree Creek & 65.3 & 20.2 \\
Swift Creek & 62.3 & 19.3 \\
Rafting Creek & 54.8 & 17.0 \\
Spears Creek & 70.8 & 21.9 \\
Colonels Creek & 69.9 & 21.6 \\
\hline
\end{tabular}

because the downstream boundary of the transport model is at station 02148306.

The tributary flows were relatively steady during the June sampling period (fig. 16); however, during the August sampling period, a few of the tributaries were influenced by localized rainfall (fig. 16). After the initial calibration using constant tributary flows, tributary flows were synthesized by using data from stations 02148000 and 02148306 as described below to produce an unsteady hydrograph for each tributary.

To develop the synthesized tributary hydrographs, the BRANCH model was run without including any tributary flow. Using a statistical program, simulated water-level and streamflow data were extracted from the BRANCH model at station 02148306 and at the confluence with the tributaries. "Difference" hydrographs were computed at station 02148306 for the June and August 1997 sampling periods by subtracting the simulated flow from the observed flow. The difference hydrographs were then shifted by the travel time to each tributary and multiplied by the percentage of the intervening drainage area. The lag time between station 02148306 and each tributary was estimated by computing correlation coefficients using multiple lag times. The lag time with the highest correlation coefficient was selected. Once the lag time was determined, tributary hydrographs were synthesized by multiplying the data points on the difference hydrograph by the selected tributary's percentage of total intervening drainage area and then shifting those data by the previously computed lag time.

The difference hydrographs were compared with hydrographs from USGS gaging stations on tributaries in or adjoining the Wateree River Basin. It was concluded that the difference-hydrograph shapes were similar to those shown at several of the tributary stations, and synthesis of the tributary hydrographs were verified by this method. 

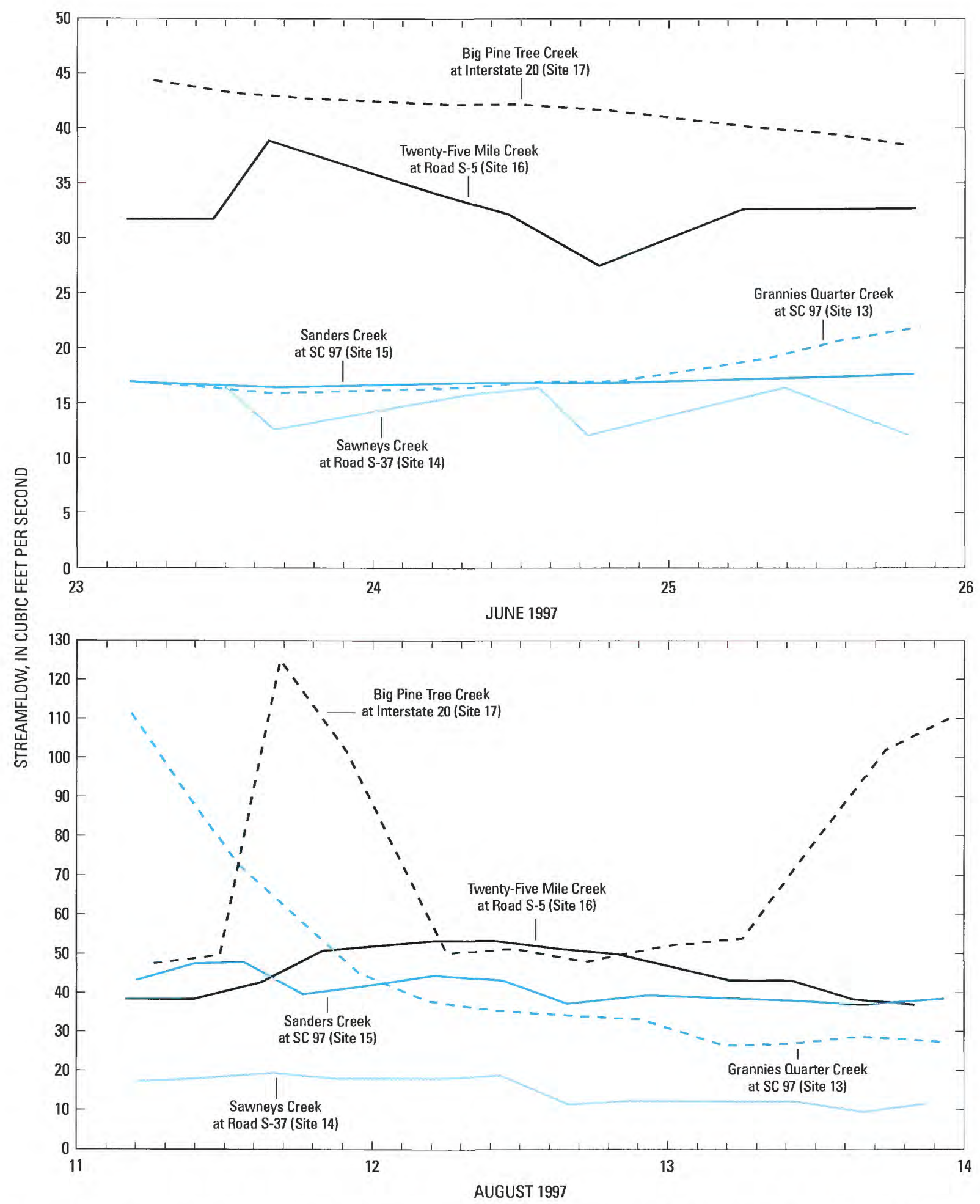

Figure 16. Streamflow measured at five tributaries to the Wateree River, S.C., June 23-25 and August 11-13, 1997. 


\section{Mass Transport}

The BLTM was used to simulate the mass transport and the water quality of the Wateree River (Jobson and Schoelhamer, 1987). The BLTM solves the convective-dispersion equation by using a Lagrangian reference frame, in which the computational nodes move with the flow (Jobson and Schoelhamer, 1987). In the Lagrangian reference frame, the continuity of mass equation is:

$$
\begin{aligned}
& \partial C / \partial t=\partial(D(\partial C) / \partial \xi) / \partial \xi \\
& +S+\Phi+K(C-C R),
\end{aligned}
$$

where

$C$ is the concentration, in milligrams per liter;

$t$ is time, in seconds:

$D$ is the longitudinal dispersion coefficient, in square feet per second;

$\xi$ is the Lagrangian-distance coordinate, in feet;

$S$ is the rate of production of the concentration, which is independent of the concentration (zero-order production rate), in milligrams per liter per second;

$\Phi$ is the rate of change in concentration due to tributary inflow, in milligrams per liter per second;

$K$ is the rate of production of the constituent, in per second: and

$C R$ is the equilibrium concentration (that is, the concentration at which the internal production ceases), in milligrams per liter.

The Lagrangian-distance coordinate, $\xi$, is given as

$$
\xi=x-x_{0}-\int_{t_{0}}^{t} u d t
$$

where

$x$ is the Eulerian (stationary) distance coordinate along the river, in feet;

$x_{0}$ is the location of the parcel of water at time $t_{0}$;

$u$ is the cross-sectional mean stream velocity, in feet per second; and

$t$ is time, in seconds.

The BLTM uses a dimensionless dispersion factor in the Lagrangian transport solutions. The dispersion factor is inversely proportional to the square of the stream velocity. The factor is defined as:

$$
D_{f}=D / \Delta t \mu^{2} \text {, }
$$

where

$D_{f}$ is dispersion factor, dimensionless;

$D$ is dispersion rate, in square feet per second;

$\Delta t$ is simulation time step, in seconds; and

$\mu$ is the representative stream velocity, in feet per second.

The BLTM assumes parcels of water are vertically and laterally mixed and that volumes are affected only by tributary flows. The variation of concentrations in a river reach is approximated by solving equation 3 for a series of parcels spaced along the river at intervals of about $\mu \Delta t$. The concentration at any point is the concentration of the parcel at that point. The assumption of completely mixed parcels may cause interpolation errors when determining the concentration at a given grid point. The accuracy of a Lagrangian model, as compared to an Eulerian model, is that this interpolation error applies only to the output computations; the grid-point concentration is not used in further computations and, therefore, the error is not compounded. In an Eulerian model, similar interpolation errors are made for every time step and grid point, and the interpolated values are used as the basis for further computations (Jobson, 1981). With the BLTM, some numerical dispersion is introduced into the solution scheme at internal junctions.

The advantages of the Lagrangian approach, compared to the Eulerian approach, are as follows: (1) the scheme is accurate in modeling the convection and dispersion terms (Jobson, 1980; Thomson and others, 1984); (2) the Lagrangian model is stable for any time step (Jobson, 1981); (3) the computer code for the algorithms is short; and (4) the conceptual model directly represents the actual transport processes.

\section{Schematization of Models}

The BRANCH model for the Wateree River was schematized by using 9 branches, 2 external boundaries, 8 internal junctions, and 40 cross sections (fig. 17). Identical cross sections were used at internal junctions. Estimated cross sections, where needed, were interpolated from measured cross sections. The 


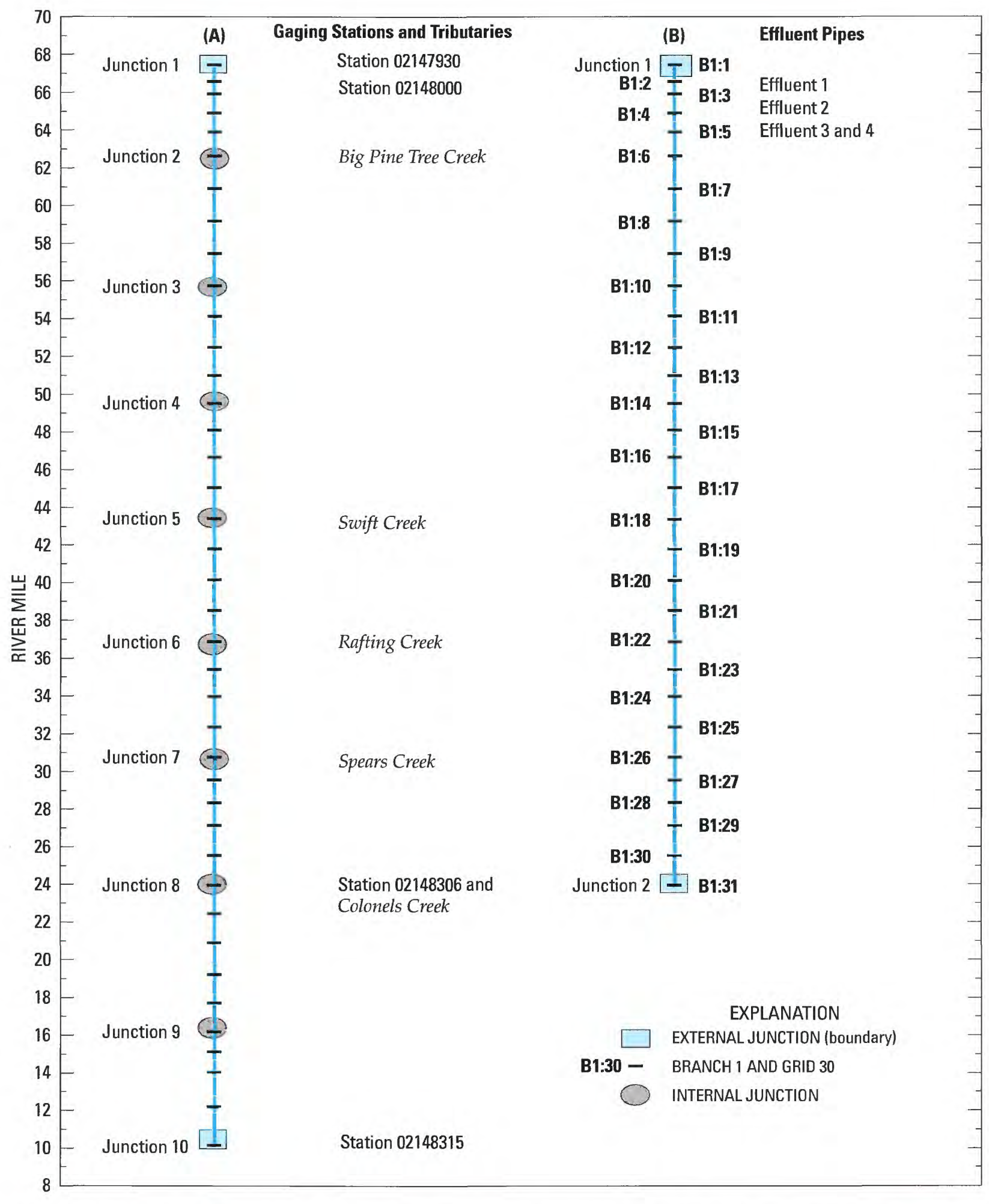

Figure 17. (A) BRANCH model and (B) Branched Lagrangian Transport Model (BLTM) schematization for the Wateree River, S.C. 
BLTM for the Wateree River was schematized by using 1 branch and 2 external boundaries (figs. 17, 18). In the schematization of the BLTM (fig. 18), internal junctions 2, 3, 4, 5, 6, and 7 in the BRANCH model schematization were removed to minimize numerical dispersion.

The BRANCH model was tested for convergence to optimize the simulation time step for the model. A finite-difference solution to the partial-differential governing equations is convergent if the numerical solution approaches the true solution of the differential equation as the numerical time step and space step are decreased (Smith, 1985). Convergence can be tested by repeated simulations of the model with a fixed set of boundary conditions for successively smaller computation time steps and space steps. The model is convergent if no further change in the model results is observed as the time step is refined (Thompson, 1992).

Model simulations using the June 1997 simulation period were generated for successively smaller computational time steps of $60,30,18,12$, and 2 minutes. Minor differences in model results occurred between 60 - and 30-minute time steps. The differences between the 30-minute and the 18-, 12-, and 2-minute time steps were considered insignificant. Therefore, a 30-minute time step was used in the model.

\section{Calibration and Validation of Streamflow}

Streamflow and water-level data collected at USGS stations 02148000,02148306 , and 02148315 during June 22-30 and August 10-18, 1997, were used to calibrate and validate the BRANCH model. Calibration was accomplished by adjusting flowresistance coefficients and cross-sectional areas until the simulated and measured flows agreed. Crosssectional areas were adjusted by raising or lowering the cross-section datum. The overbank storage volumes were estimated during a previous study and were not changed during this calibration (Hurley, 1991). The parameters used to calibrate the model were not changed during the validation. Because the model will ultimately be used to simulate the fate and mass transport of conservative and non-conservative constituents, emphasis was placed on the streamflow simulations during the calibration and validation. Consequently, if the model is simulating the streamflow within an acceptable range, the appropriate volume of water is being moved through the system.
Simulated and measured hydrographs of streamflow used to calibrate and validate the model are shown in figures 19 and 20, respectively.

Summary statistics for the streamflow simulations were generated to quantify the error of calibration and validation simulations (table 11). The timing error was computed by correlating measured values with the simulated values offset forward or backward in time. The time offset having the highest correlation coefficient was assumed to be the timing error of the simulated hydrographs. After correcting the

Table 11. Summary statistics for the streamflow calibration and validation simulations for the Wateree River, S.C.

\begin{tabular}{cccc}
\hline $\begin{array}{c}\text { Station no. } \\
\text { (fig. 3) }\end{array}$ & $\begin{array}{c}\text { Timing error } \\
\text { (minutes) }\end{array}$ & $\begin{array}{c}\text { Residual } \\
\text { (percent) }\end{array}$ & $\begin{array}{c}\text { Standard } \\
\text { error }^{\mathbf{c}} \\
\text { (percent) }\end{array}$ \\
\hline \multicolumn{4}{c}{ Calibration (June 22-29, 1997) } \\
\hline 02148306 & -60 & -3.5 & 0.6 \\
02148315 & -60 & 1.1 & 1.3 \\
\hline \multicolumn{4}{c}{ Validation (August 10-18, 1997) } \\
\hline 02148306 & -30 & -5.9 & 2.7 \\
02148315 & -90 & 7.1 & 3.2 \\
\hline
\end{tabular}

${ }^{a}$ Negative timing error means the simulated streamflow occurred earlier than the measured streamflow.

${ }^{\mathrm{b}}$ Residual percentage was computed by subtracting the measured streamflow from the simulated streamflow and dividing the difference by the measured streamflow, after adjusting the simulated streamflow for timing errors.

${ }^{\mathrm{c}}$ Standard error percentage was computed by averaging the error percentage computed by taking the antilog of 1 plus the standard deviation of base 10 logarithmic residuals and 1 minus the standard deviation of base 10 logarithmic residuals.

simulations for the timing error, the percentages of residual and standard errors were calculated by using the mean and standard deviation of the differences of the logarithms of the simulated and measured streamflow, respectively. A positive percentage of residual indicates an over-prediction of streamflow. The results show that the percentages of residual and standard error were relatively small. Station 02148315 had the highest percentages of residual and standard error for the validation simulation. However, as previously mentioned, during the steady-state flow period in August, the streamflow actually decreased between USGS stations 02148306 and 02148315 . This decrease in flow was not accounted for in the model. 


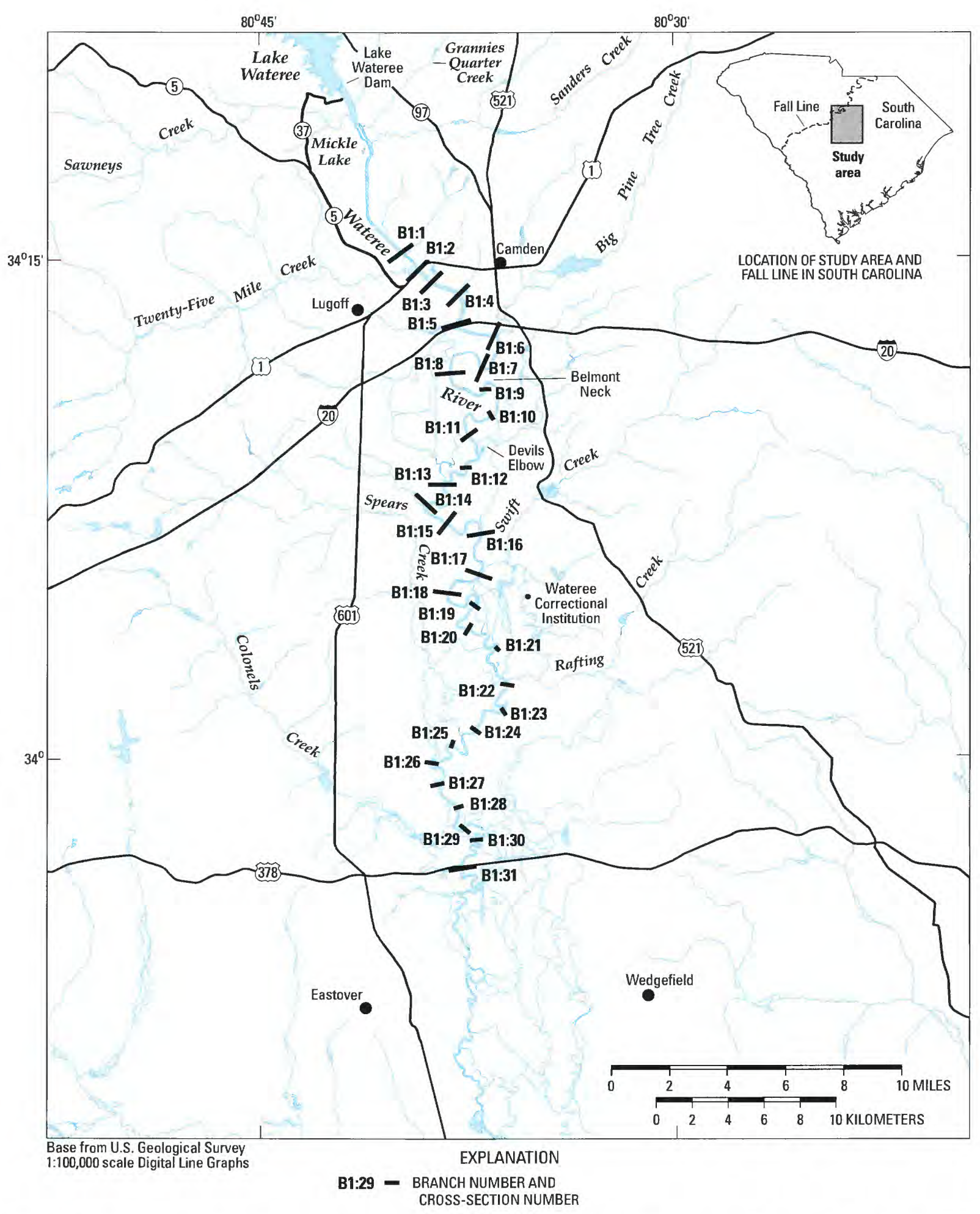

Figure 18. Locations of branches and cross sections used in the Branched Lagrangian Transport Model (BLTM) for the Wateree River, S.C. 

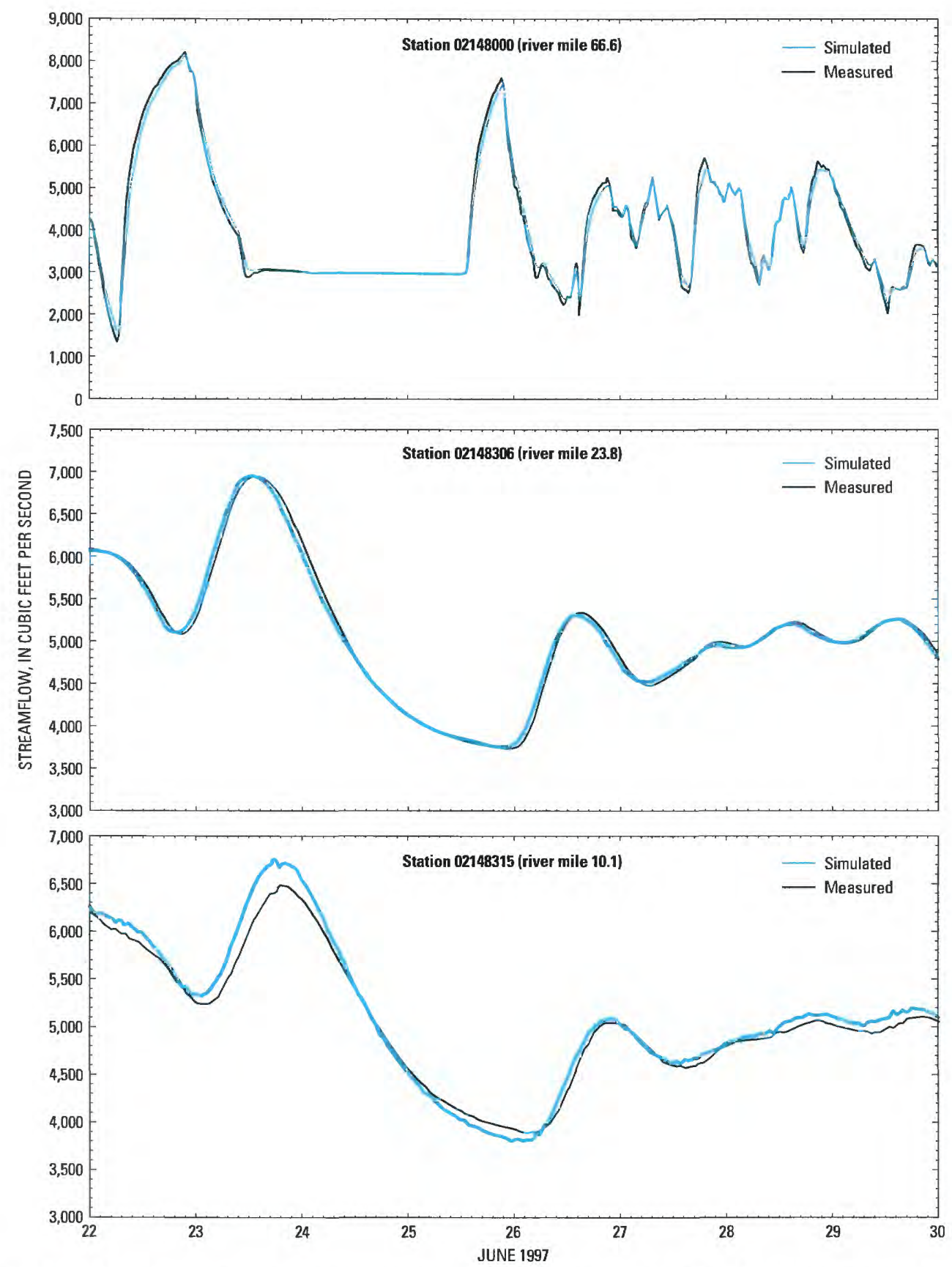

Figure 19. Simulated and measured streamflow used in the BRANCH model calibration for three locations on the Wateree River, S.C., June 22-30, 1997.

Consequently, it would be expected that the simulation would have a larger residual and standard error at station 02148315 .

The flow model is considered validated over the range of conditions used in the calibration and validation process. Caution, therefore, should be used when simulating flows outside of the range of flows used for calibration and validation.

\section{Streamflow Sensitivity Analysis}

The sensitivity of the simulated streamflow data to changes in flow resistance, downstream gage datum, cross-section elevations, and boundary conditions was analyzed by using streamflow data collected during June 22-30, 1997, at site 9 (RM 52.49). Site 9 was chosen because it is located downstream from all 

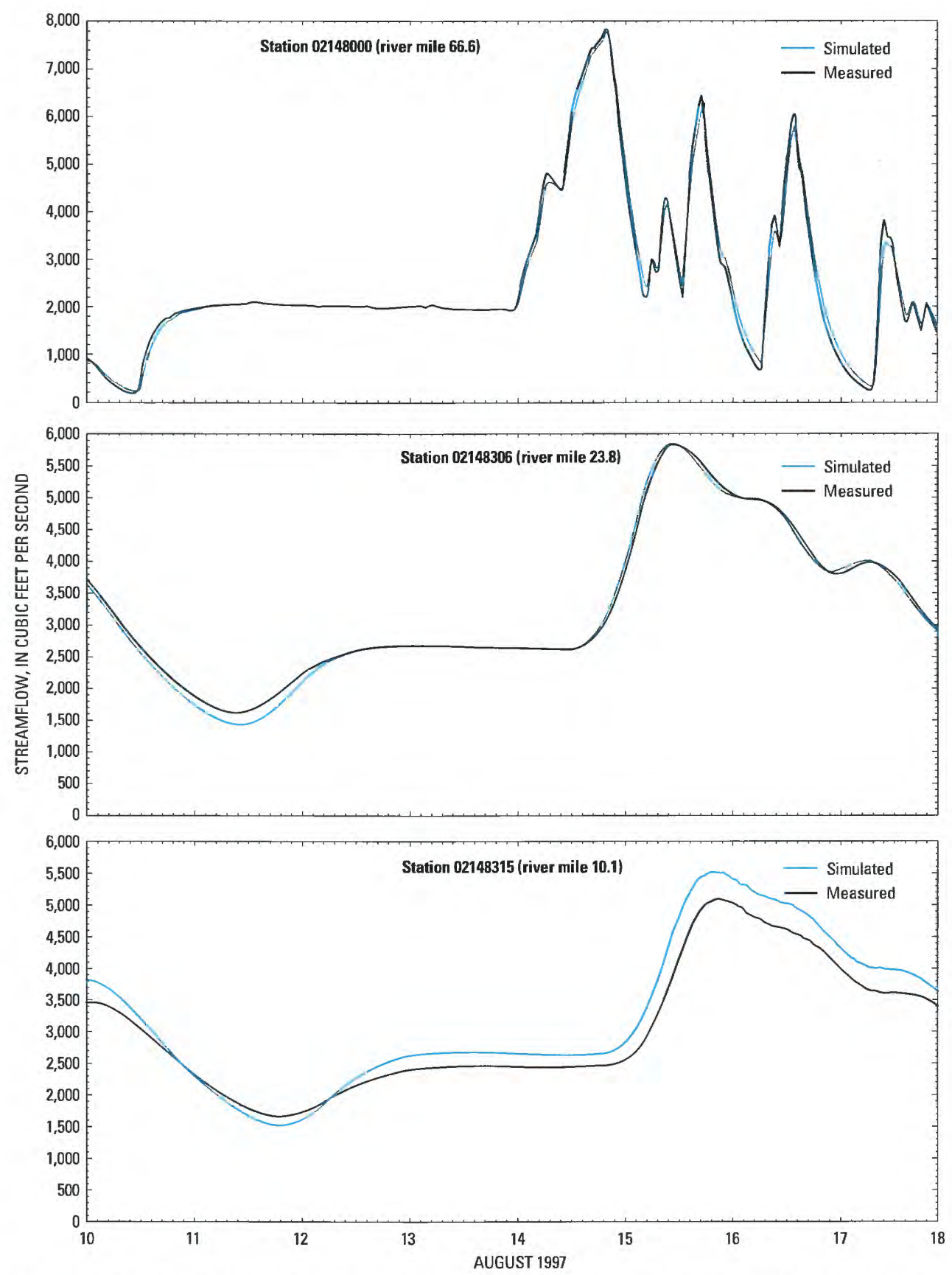

Figure 20. Simulated and measured streamflow used in the BRANCH model validation for three locations on the Wateree River, S.C., August 10-18, 1997.

effluent dischargers and the location of the critical or minimum DO concentrations, and is approximately halfway between the upstream and downstream boundary. The sensitivity analysis showed that decreasing the flow-resistance coefficients at all cross sections by 35 percent changed daily-mean streamflow by -4.5 to 3.9 percent, with a median of 1.6 percent. Increasing the roughness coefficients by 35 percent changed the daily-mean streamflow by -3.3 to 2.3 percent, with a median of 0.3 percent. Next, the downstream boundary gage datum was increased and decreased by $1.0 \mathrm{ft}$. A positive datum adjustment of 
$1.0 \mathrm{ft}$ as well as a negative datum adjustment of $1.0 \mathrm{ft}$ at USGS station 02148315 had no statistically significant impact on the daily-mean streamflow. A change in the elevations of the cross sections defining the channel geometry effectively adjusted the volume of water in the system by either raising the cross section (decreasing the volume) or lowering the cross section (increasing the volume). Applying a 1.0-ft positivedatum adjustment as well as a 1.0 -ft negative-datum adjustment to all of the cross sections had no statistically significant effect on the daily-mean streamflow. Results of the sensitivity analysis are shown in figure 21 .
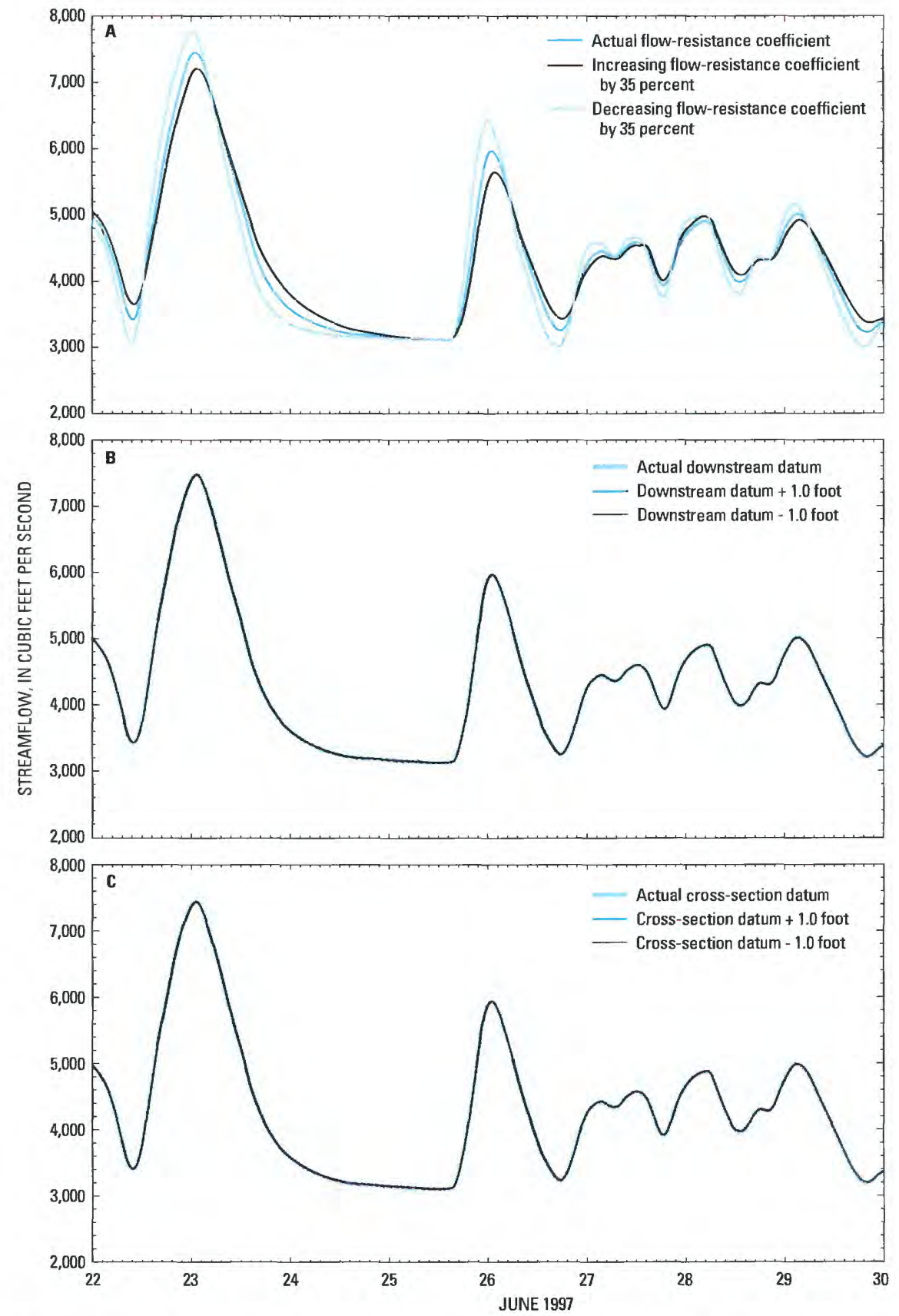

Figure 21. Sensitivity of simulated streamflow to changes in (A) flow-resistance coefficient, (B) downstream boundary gage datum, and (C) cross-sectional datum for USGS station 021480708 (site 9, RM 52.5) on the Wateree River, S.C., June 22-30, 1997. 
Calibration and Validation of Mass Transport

The BLTM assumes complete lateral and vertical mixing. However, from the time-of-travel response curves at sites 5 and 7 (figs. 22,23), it can be seen that the tracer was not completely mixed laterally. For the calibration and validation of the transport model, a composite time-of-travel curve was used at sites 5 and 7. For the June data, all three response curves were used for averaging at sites 5 and 7. For the August data, only the response curves measured at the 50- and 83.3-percent cumulative discharge locations were used to obtain the composite curve at site 5. The 16.7percent cumulative discharge response curve was not used because the response curve was so small it would have significantly skewed the composite curve.
The timing of the simulated peak concentration was first adjusted by making minor changes to the flowresistance coefficients in the BRANCH model. These adjustments were made until the difference between the measured and simulated peak concentrations were minimized. Next, the area of the simulated curve was calibrated by adjusting the dispersion factors in BLTM. The dispersion factors were determined by minimizing the percent difference in the simulated and observed dye-cloud areas (table 12). The areas under the dye clouds were computed by integration. The dispersion factors ranged from 0.08 to 0.15 . In addition, a decay coefficient of 0.05 was included at grids 1 through 4 . The decay coefficient accounts for dye losses and is not used in the BLTM water-quality simulations.

Simulated and measured dye concentrations for the calibration and validation simulations are shown in figures 24 and 25, respectively.

Table 12. Simulated and measured peak travel time and dye-cloud area for six locations on the Wateree River, S.C., June 24-25 and August 11-13, 1997

[hr, hour; $\mu \mathrm{g} / \mathrm{L}$, microgram per liter]

\begin{tabular}{|c|c|c|c|c|c|c|c|}
\hline $\begin{array}{l}\text { Site no. } \\
\text { (fig. 9) }\end{array}$ & $\begin{array}{l}\text { River } \\
\text { mile }\end{array}$ & $\begin{array}{c}\text { Time of } \\
\text { measured } \\
\text { peak } \\
\text { (hours after } \\
\text { injection) }\end{array}$ & $\begin{array}{c}\text { Time of } \\
\text { simulated } \\
\text { peak } \\
\text { (hours after } \\
\text { injection) }\end{array}$ & $\begin{array}{c}\text { Time } \\
\text { difference } \\
\text { (hr) }\end{array}$ & $\begin{array}{c}\text { Measured } \\
\text { area } \\
(\mu \mathrm{g} / \mathrm{L}) \mathrm{hr}\end{array}$ & $\begin{array}{c}\text { Simulated } \\
\text { area } \\
(\mu \mathrm{g} / \mathrm{L}) \mathrm{hr}\end{array}$ & $\begin{array}{c}\text { Percent } \\
\text { difference }\end{array}$ \\
\hline \multicolumn{8}{|c|}{ June 1997 Time-of-travel study } \\
\hline 5 & 67.4 & 36.33 & 36.25 & 0.08 & 17.4 & 18.0 & -3.2 \\
\hline 7 & 63.9 & 39.40 & 39.75 & -.35 & 15.7 & 15.0 & 4.1 \\
\hline 8 & 57.3 & 45.25 & 44.75 & -.50 & 16.1 & 14.2 & 12.0 \\
\hline 9 & 52.5 & 50.75 & 50.75 & .00 & 15.1 & 14.2 & 6.3 \\
\hline 11 & 35.8 & 65.50 & 65.75 & -.25 & 13.9 & 13.0 & 6.7 \\
\hline 12 & 23.8 & 77.00 & 76.75 & .25 & 10.2 & 10.7 & -5.2 \\
\hline \multicolumn{8}{|c|}{ August 1997 Time-of-travel study } \\
\hline 5 & 67.4 & 10.77 & 10.75 & .02 & 9.8 & 11.1 & -13.0 \\
\hline 7 & 63.9 & 14.25 & 14.75 & -.50 & 9.8 & 9.2 & 5.9 \\
\hline 8 & 57.3 & 20.92 & 20.75 & .17 & 8.4 & 8.8 & -4.1 \\
\hline 9 & 52.5 & 26.25 & 26.75 & -.50 & 8.0 & 8.9 & -11.2 \\
\hline 11 & 35.8 & 44.00 & 44.25 & -.25 & 8.6 & 8.2 & 5.4 \\
\hline 12 & 23.8 & \multicolumn{6}{|c|}{ No data collected } \\
\hline
\end{tabular}



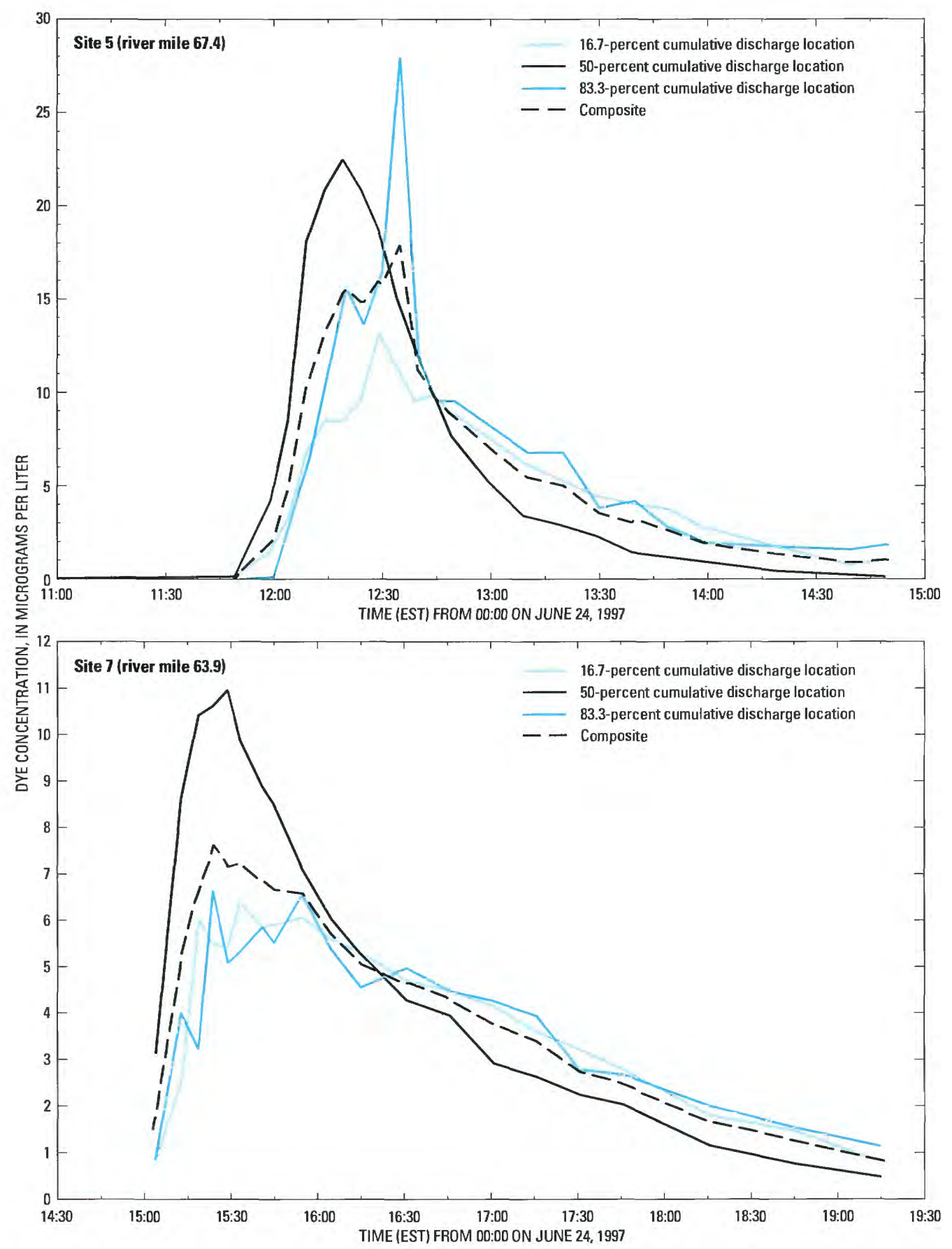

Figure 22. Time-of-travel response curves for two locations on the Wateree River, S.C., June 24, 1997. 

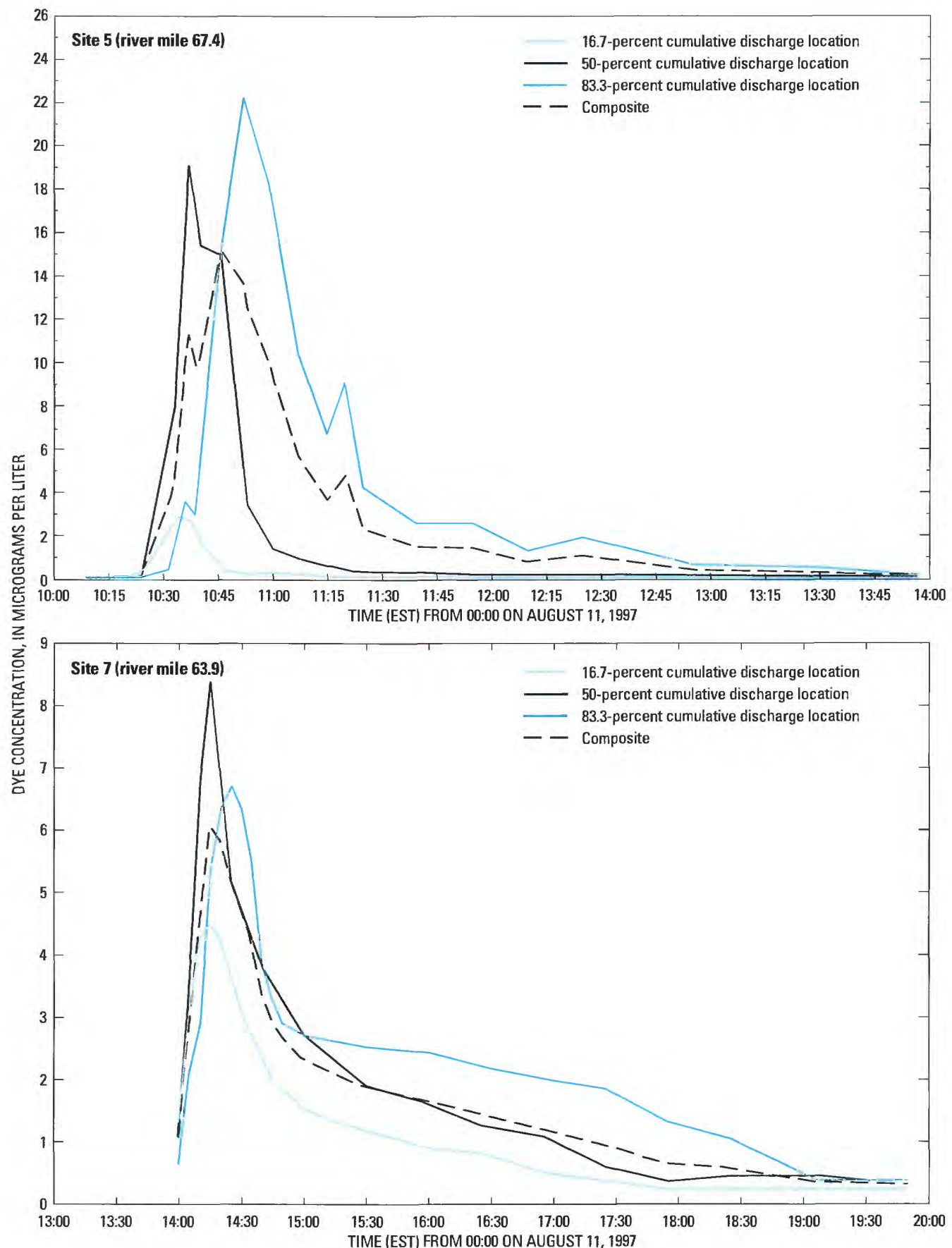

Figure 23. Time-of-travel response curves for two locations on the Wateree River, S.C., August 11, 1997. 

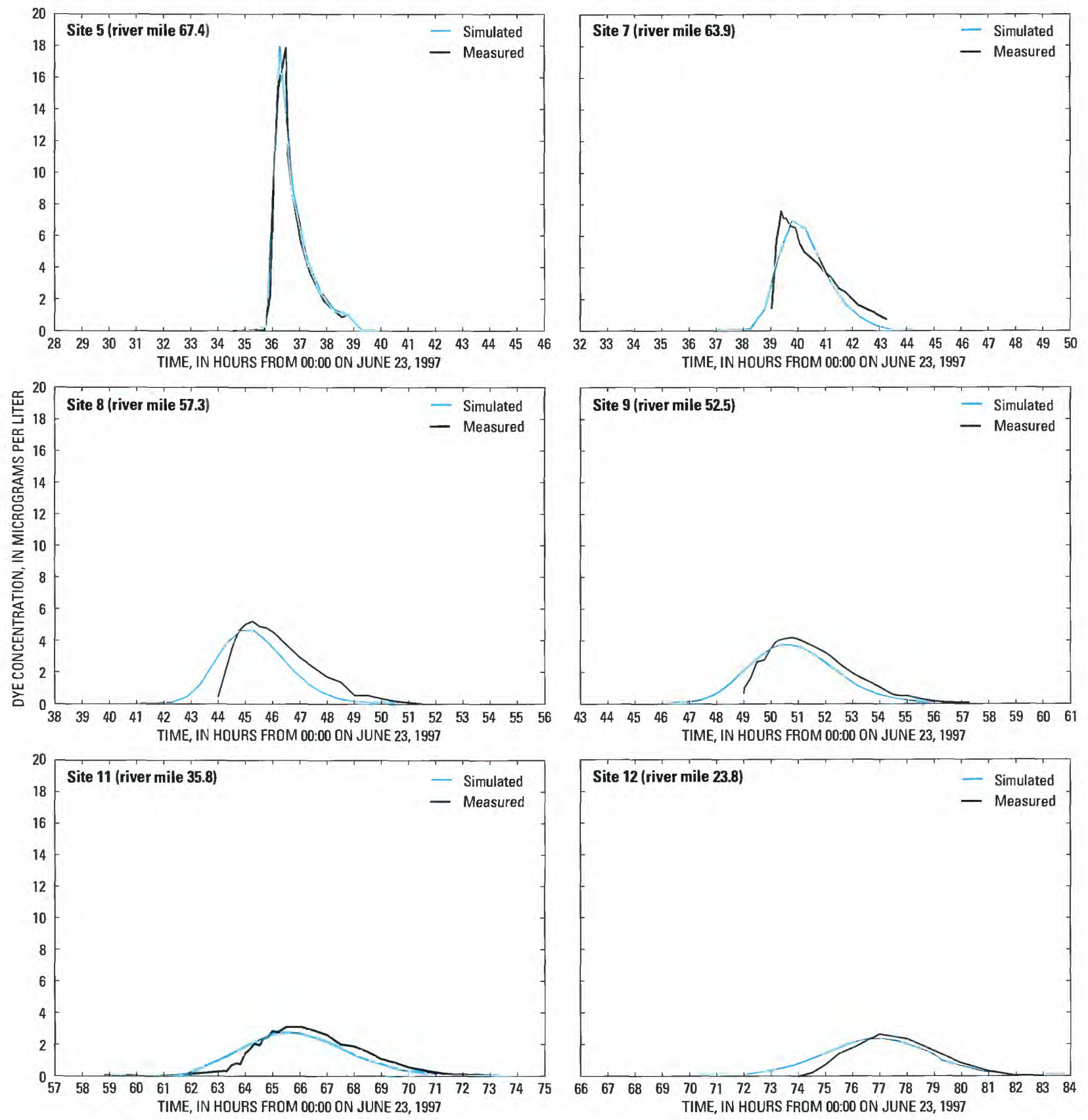

Figure 24. Simulated and measured dye concentration calibration for six locations on the Wateree River, S.C., June 23-25, 1997. 

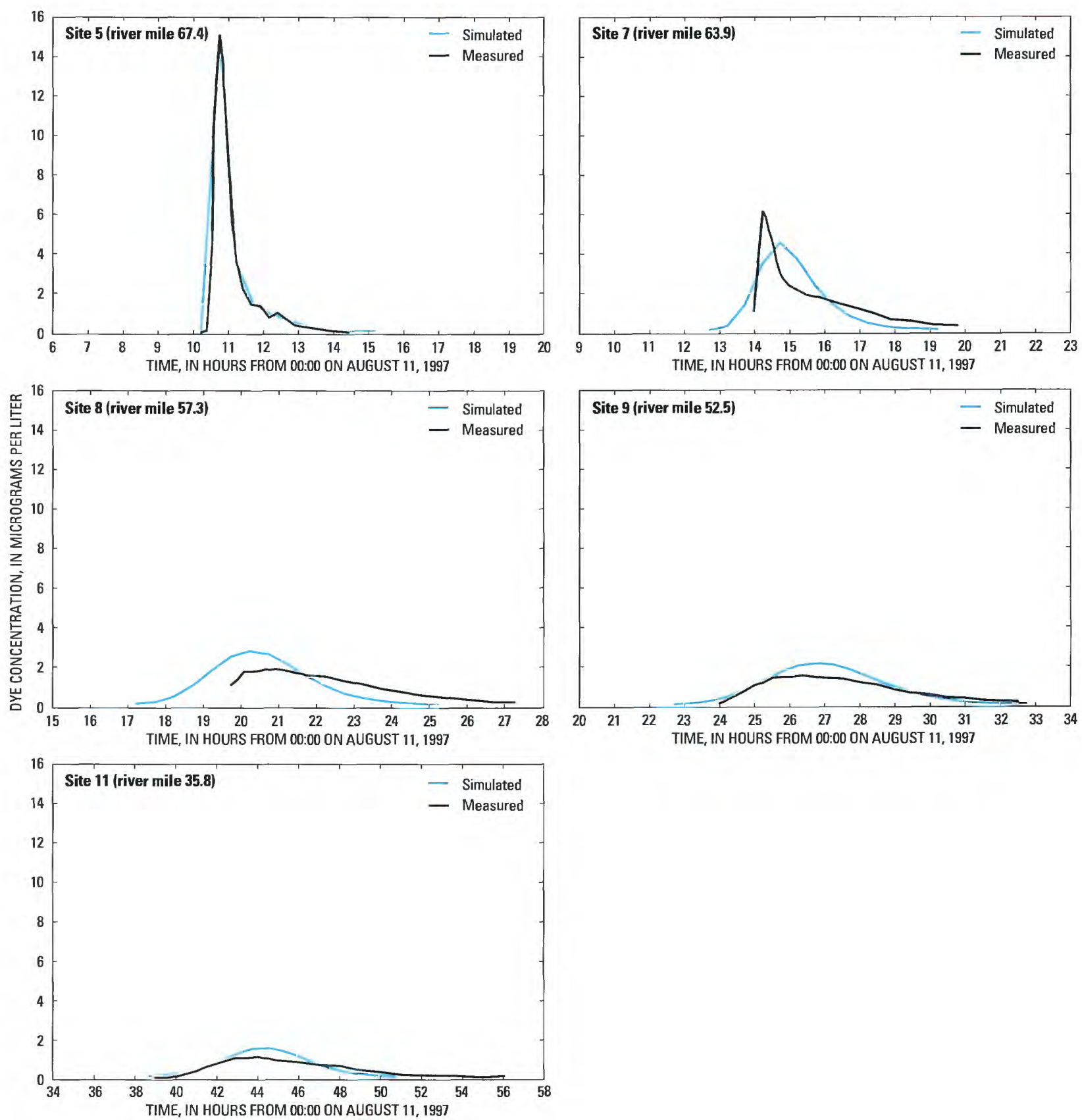

Figure 25. Simulated and measured dye concentration validation for five locations on the Wateree River, S.C., August 11-13, 1997. 
reach the equilibrium temperature and remain at this temperature as long as the meteorologic conditions (solar radiation, atmospheric radiation, wind speed, air temperature, and relative humidity) remain constant.

Applying the principle of conservation of thermal energy to a one-dimensional open channel, the conservation of temperature equation, in its Lagrangian form, is as follows:

$$
\begin{aligned}
& d T / d t+U d t / d x-\left[D_{x}\left(d^{2} T / d x^{2}\right)\right] \\
& =\left(H_{t} W\right) /\left(C_{p} \rho A\right),
\end{aligned}
$$

where

$T$ is the cross-sectional average water temperature;

$t$ is time;

$U$ is stream velocity;

$x$ is the longitudinal coordinate;

$D_{x}$ is the longitudinal dispersion coefficient;

$H_{t}$ is the flux of thermal energy from the air to the water;

$W$ is the top width of the channel;

$C_{p}$ is the specific heat of water at constant pressure;

$\rho$ is the density of water; and

$A$ is cross-sectional area.

The term on the right side of equation 6 represents the rate of change in water temperature caused by the exchange of energy between the atmosphere and water.

The simulation of temperature can be simplified by determining the equilibrium temperature. It is easier, and often more acceptable, to estimate the equilibrium temperature than to measure all the necessary meteorologic inputs (solar radiation, atmospheric radiation, wind speed, air temperature, and relative humidity) necessary for a detailed heat budget. Time-series estimates of equilibrium temperature for the calibration and validation time periods were computed by using the program EQULTMP (Jobson, 1997). The program uses inputs of daily extremes of air temperature (and their respective times) and average daily wind speed to compute the equilibrium temperatures for a specified time step.

The QUAL2E subroutine in the BLTM simulates the growth of phytoplankton, which are dependent on solar radiation. Time series estimates of solar radiation were computed by using the program SOLAR (Jobson, 1997). Inputs for the program include longitude and latitude of the boundary location, longitude of the local time meridian, altitude of sunrise and sunset, atmospheric pressure, coefficients in empirical equation to determine atmospheric precipitation, cloud cover, and dewpoint temperature.

A modified version of QUAL2E kinetics in the BLTM was applied to the Ashley, the Cooper, and the Wando Rivers (Conrads and Smith, 1997; Conrads, 1998). Modifications to the model include a loss factor for the oxidation of nitrite to nitrate, source terms for BOD and organic nitrogen, and a settling term for orthophosphorus (fig. 26). An additional reaeration algorithm for estuarine environments that estimates reaeration as a function of channel depth and wind speed was added to the BLTM (Thomann and Fitzpatrick, 1982) and evaluated for the Ashley River application. This same version of the QUAL2E kinetics was applied to the Wateree River.

\section{Calibration and Validation of Water Temperature}

Daily high and low air temperatures and wind speed data from Columbia Airport were used to estimate the necessary meteorologic input data for each data set of wind speed, equilibrium temperature, and solar radiation (W. Tyler, State Climatology Office, South Carolina Department of Natural Resources, written commun., 1998). Water-temperature simulations were calibrated by adjusting the free convection and mass-transfer coefficients in the wind function of the BLTM. The calibration was refined and improved by adjusting the equilibrium temperatures at the upstream boundary by 5 percent. The simulated water temperatures during the calibration and validation periods are shown in figures 27 and 28, respectively.

\section{Calibration and Validation of Nutrients, Biochemical Oxygen Demand, and Dissolved Oxygen}

The BLTM for the Wateree River was calibrated and validated by using nutrient data collected during June 23-25 and August 11-13, 1997, respectively. Ten water-quality constituents were simulated-water temperature, DO, algal biomass, organic nitrogen, ammonia, nitrite, nitrate, organic phosphorus, orthophosphorus, and ultimate carbonaceous 
SIMULATION OF TEMPERATURE, NUTRIENTS, BIOCHEMICAL OXYGEN DEMAND, AND DISSOLVED OXYGEN

The BLTM uses the water-quality reaction kinetics used in the QUAL2E model to simulate the fate and transport of nutrients, BOD, and DO (Brown and Barnwell, 1987; Jobson and Schoelhamer, 1987). The model can simulate the effect of as many as 10 water-quality constituents on DO concentration. The model also can simulate multiple wastewater discharges, withdrawals, tributary flows, and incremental inflows and outflows. A conceptualization of the constituents and their interactions in the QUAL2E subroutine in the BLTM model is shown in figure 26. The rates of most chemical and biological reactions in the QUAL2E subroutine are temperature dependent; therefore, it is necessary to accurately simulate the water temperature of the system. The QUAL2E subroutine uses an equilibrium temperature algorithm to simulate water temperature (Jobson, 1977, 1981). The equilibrium temperature is defined as the water temperature at which the net surface heat exchange becomes zero. For example, a pool of water would

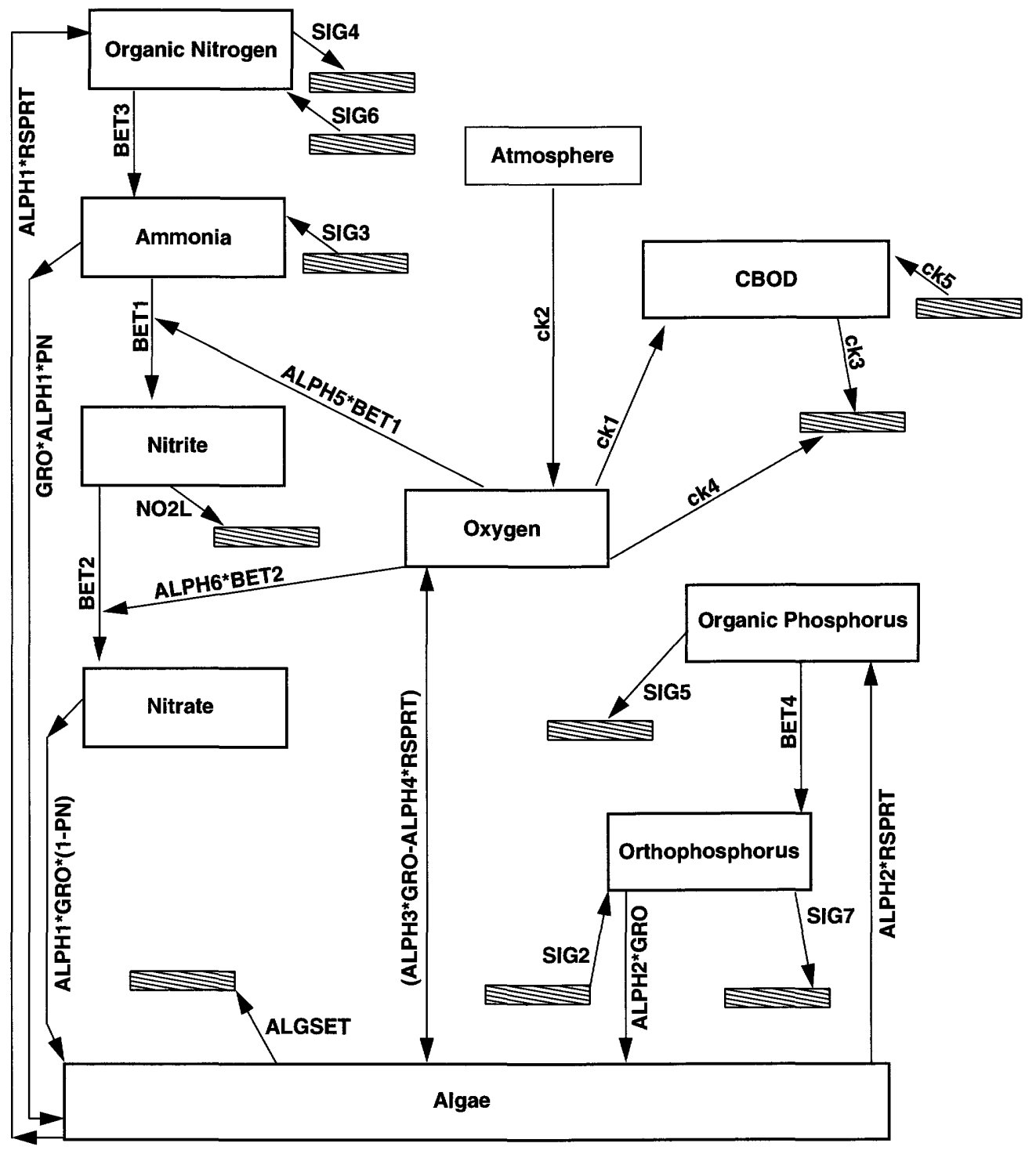

Figure 26. Major constituent interactions in the QUAL2E subroutine of the Branched Lagrangian Transport Model (BLTM). 

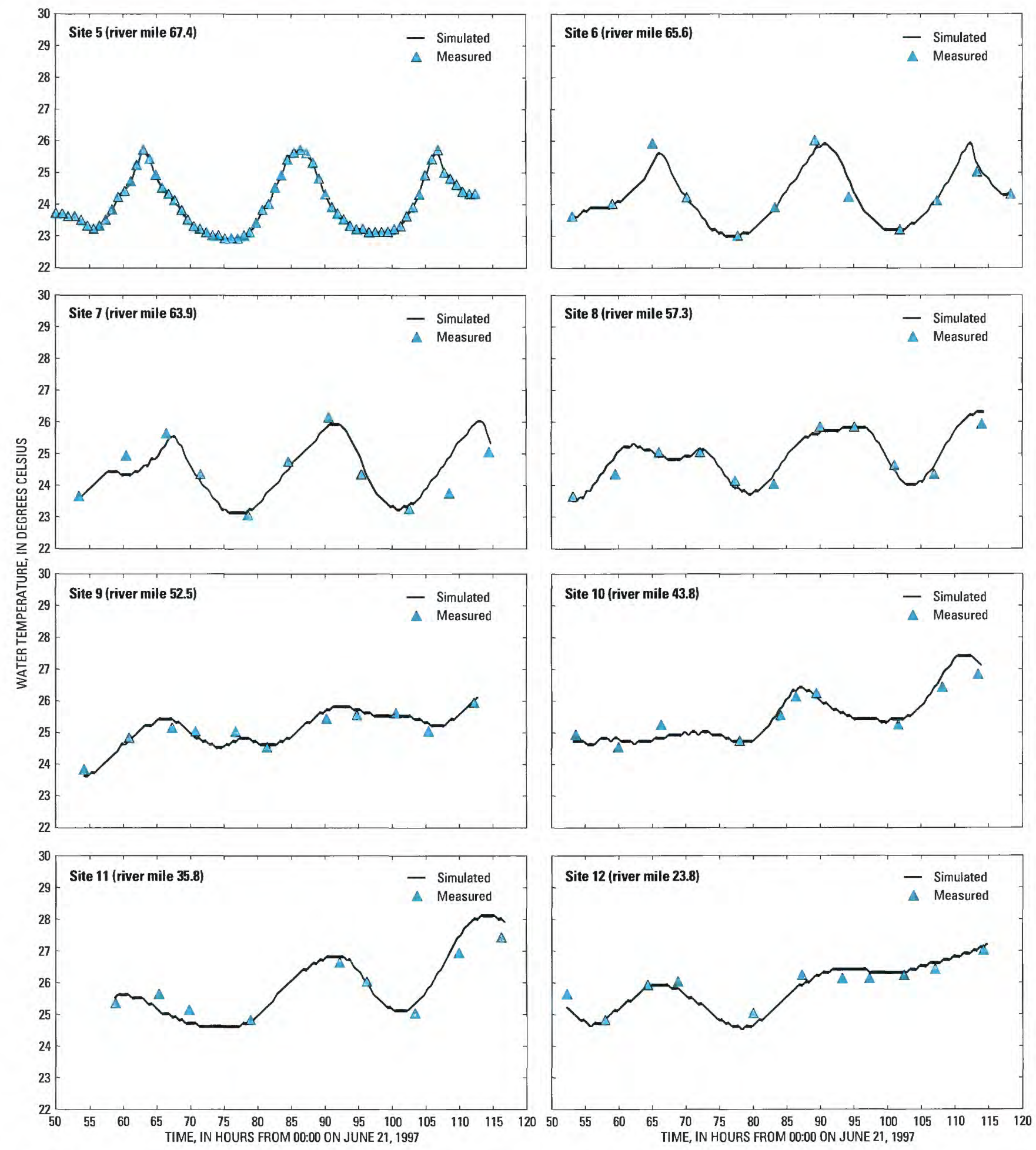

Figure 27. Simulated and measured water temperatures used in the Branched Lagrangian Transport Model (BLTM) calibration for eight locations on the Wateree River, S.C., June 23-25, 1997. 

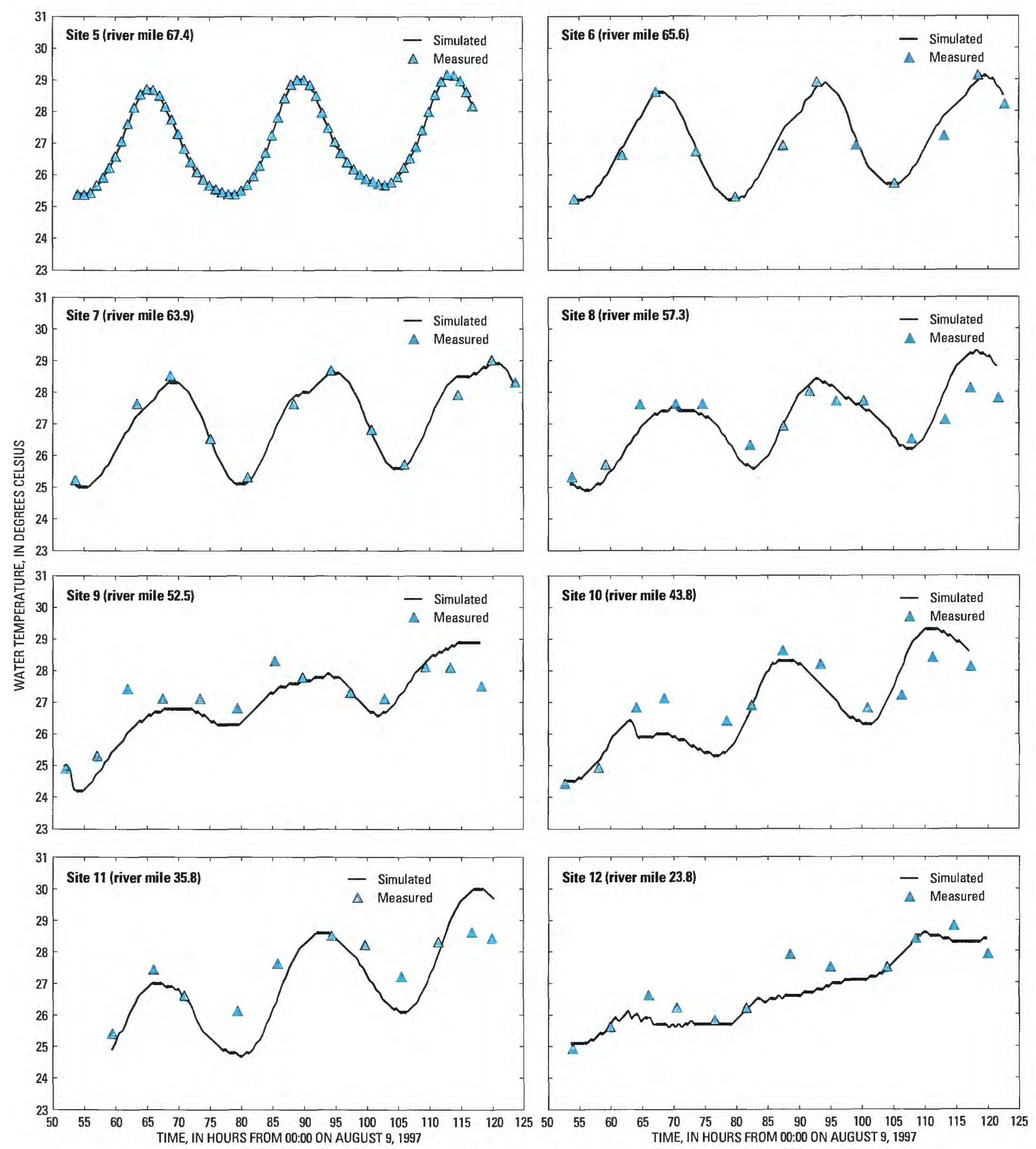

Figure 28. Simulated and measured water temperatures used in the Branched Lagrangian Transport Model (BLTM) validation for eight locations on the Wateree River, S.C., August 11-13, 1997. 
biochemical oxygen demand $\left(\mathrm{CBOD}_{\mathrm{u}}\right)$. $\mathrm{DO}$ is the water-quality constituent of most interest to the SCDHEC in defining and managing the river's quality. DO concentration is dependent on many factors, including water temperature, streamflow, atmospheric reaeration, photosynthesis, plant and animal respiration, BOD, nitrification, and benthic oxygen demand. Wastewater permittees discharge ammonia and BOD into the Wateree River; these constituents consume DO during oxidation and decay, respectively.

Four point-source discharges were sampled and included in the BLTM water-quality model. The discharge pipes are located at RM 67.1, RM 66.1, RM 65.0, and RM 64.8. Because the discharges at RM 65.0 and RM 64.8 are located so close together, water-quality constituents and flow data were combined and included as one boundary station. The constituents were mixed by using the conservative mixing formula:

$$
C_{\text {mixed }}=\left(C_{1} Q_{1}+C_{2} Q_{2}\right) /\left(Q_{1}+Q_{2}\right)
$$

where

$C_{\text {mixed }}$ is the concentration after mixing, in milligrams per liter;

$C_{1}$ is the concentration at point 1 , in milligrams per liter;

$Q_{1}$ is the flow at point 1 , in cubic feet per second;

$C_{2}$ is the concentration at point 2 , in milligrams per liter; and

$Q_{2}$ is the flow at point 2 , in cubic feet per second.

The BLTM grid location nearest each point-source discharge was used as the boundary location.

The BLTM water-quality model was calibrated by adjusting the constant (global) and variable (local) kinetic rate coefficients within ranges described by Bowie and others (1985) and Brown and Barnwell (1987) until the simulated constituent concentrations approximated the measured concentrations. Simulated concentrations were considered acceptable when the average simulated constituent concentrations for the period of measured data were within the range of observed concentrations for a given location. Kinetic rate coefficients that were used in the model and recommended values are listed in table 13.

The general approach to the model calibration using the June 1997 data was to calibrate the constituents in the order in which they react with each other beginning with algae. The last constituent to be calibrated was DO. The reaeration coefficients measured during the August sampling were used to help evaluate the QUAL2E reaeration algorithm chosen for the Wateree River. The reaeration algorithm by Churchill and others (1962) was used in the model. The reaeration coefficients computed from the August 1997 data between sites 7 and 8 ranged from 1.3 to 3.2 per day. The values computed using the Churchill formula were determined to be similar.

$\mathrm{CBOD}_{\mathbf{u}}$ samples were collected at each sampling site. The results were used to compute decay coefficients and f-ratios (a ratio between $\mathrm{CBOD}_{\mathrm{u}}$ and the 5-day BOD). However, during a review of the private laboratory data, many of the BOD analyses were determined to be unacceptable, and it was concluded that the samples should not be used to estimate f-ratios for the dischargers. The f-ratios currently used by the SCDHEC were used in the model. An average $\mathrm{CBOD}_{\mathrm{u}}$ decay rate of 0.16 per day was computed from the acceptable river samples and was used in the BLTM water-quality model.

The model simulations were started 2 days prior to the actual sampling period to allow for flushing of the estimated initial conditions at each site. Mean concentrations of the measured data were used at the boundaries during the warm-up period. The first simulated data used at each site to compute the statistics comparing the simulated and measured values were determined based on the travel time of the first sample at the upstream boundary. The travel time was estimated by using the travel time of the dye-cloud centroid. This procedure was used to ensure that the initial-value data had passed each sampling site before statistics were computed. As a result, the downstream sites have fewer simulated and observed values used in the statistics than do the upstream sites. Results of the BLTM water-quality model calibration and validation are presented as time-series graphs of each constituent at each sampling location (figs. 29-44). In addition, the statistics for the calibration and validation simulations are listed in tables 14 and 15, respectively.

The calibration and validation simulations show that the model generally follows the trend of the measured data for most constituents. The validation simulations for the organic nitrogen followed the general trend of the measured data fairly well.

However, the calibration simulations for the organic nitrogen typically were lower than the measured data, possibly indicating nonpoint sources that were not captured in the model. Because the lower Wateree 


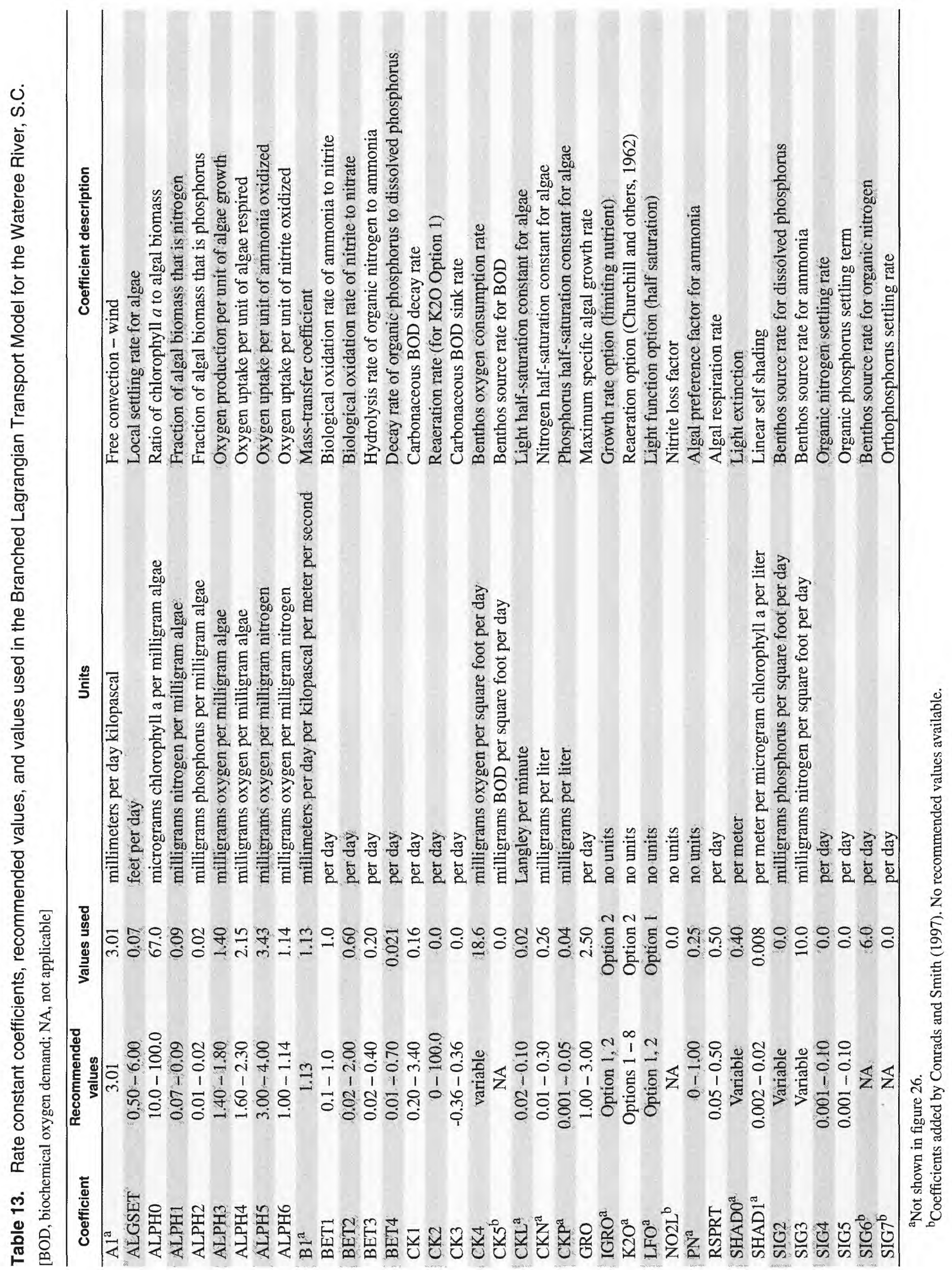



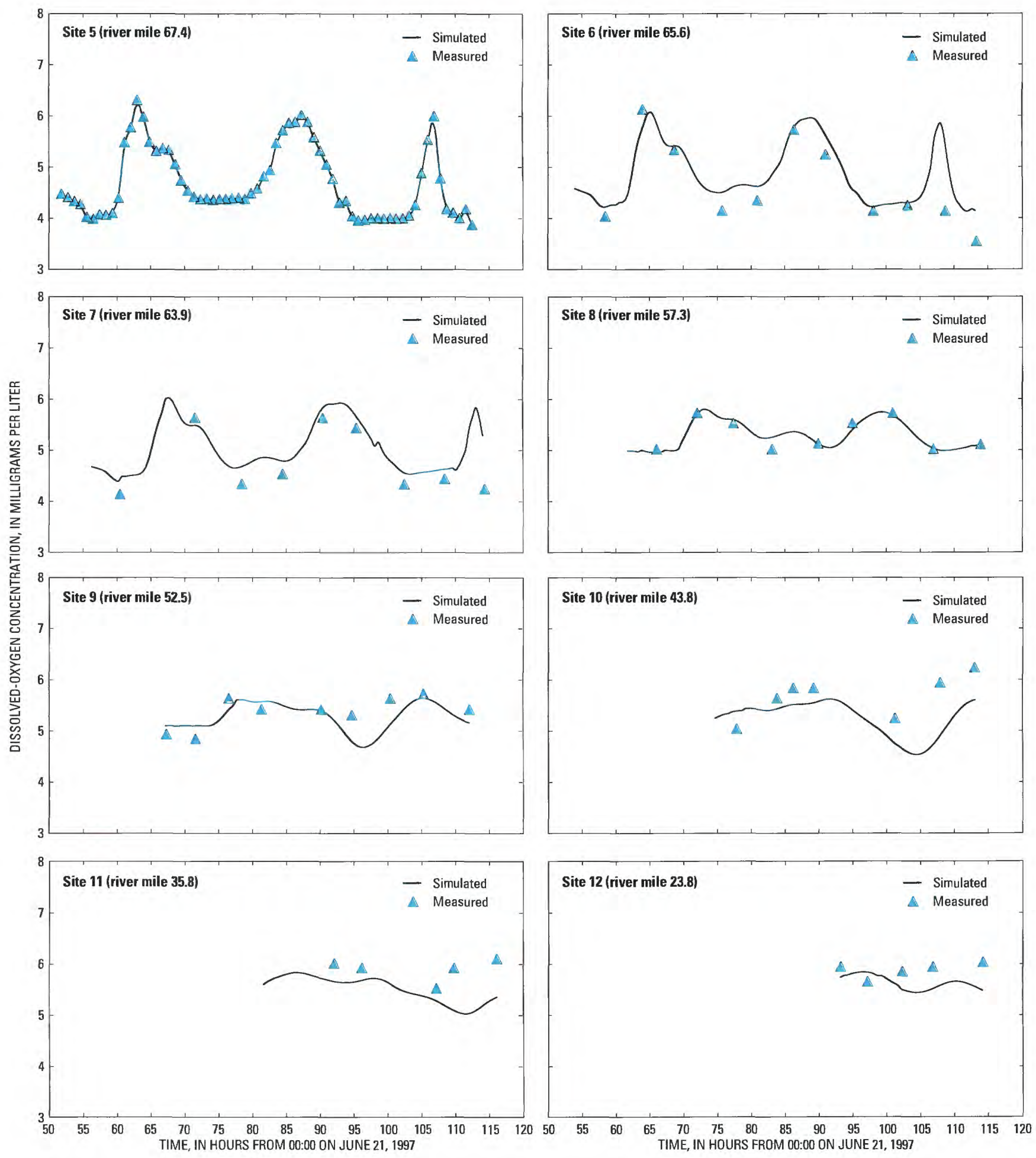

Figure 29. Simulated and measured dissolved-oxygen concentrations used in the Branched Lagrangian Transport Model (BLTM) calibration for eight locations on the Wateree River, S.C., June 23-25, 1997. 

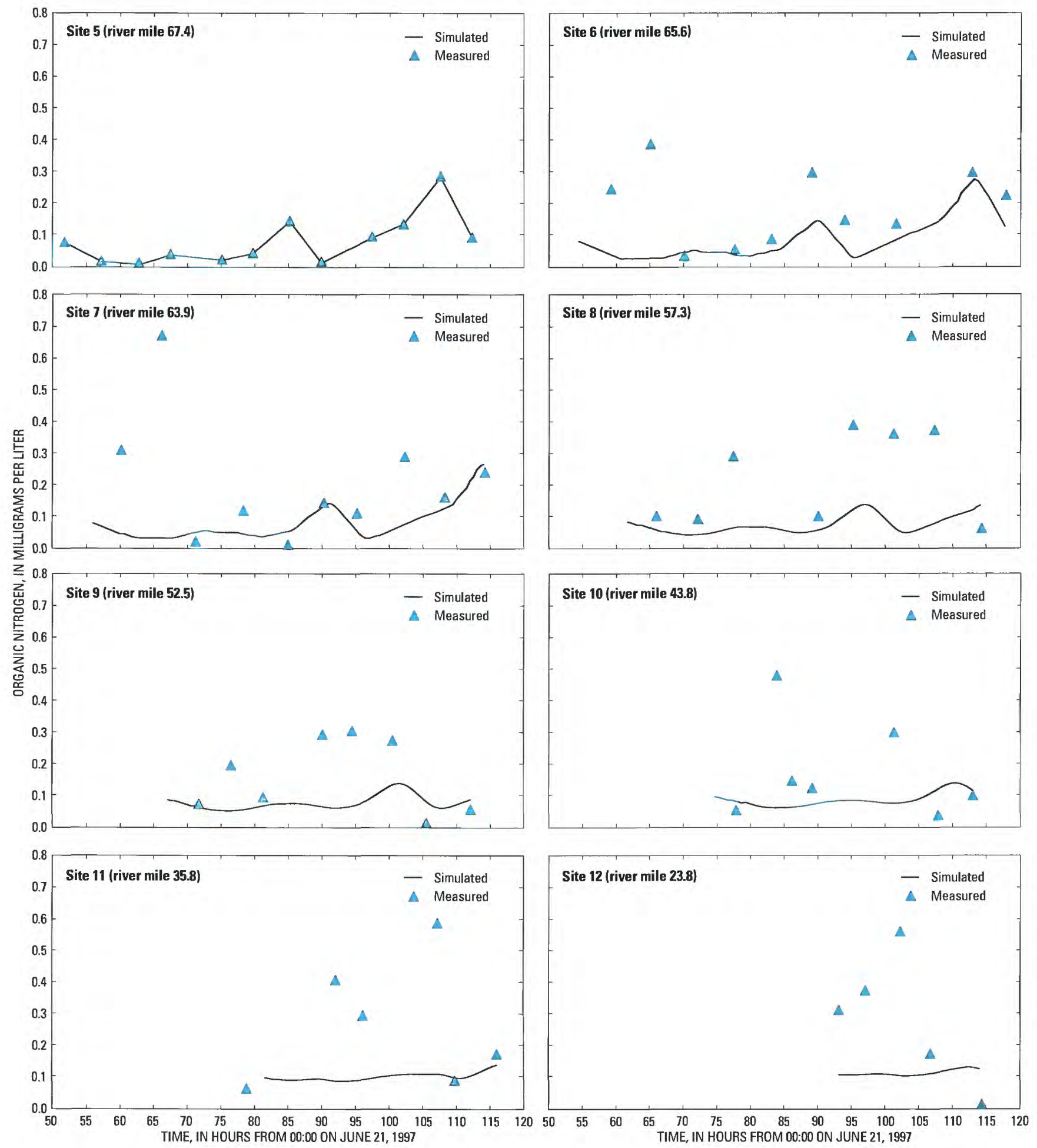

Figure 30. Simulated and measured organic nitrogen concentrations used in the Branched Lagrangian Transport Model (BLTM) calibration for eight locations on the Wateree River, S.C., June 23-25, 1997. 

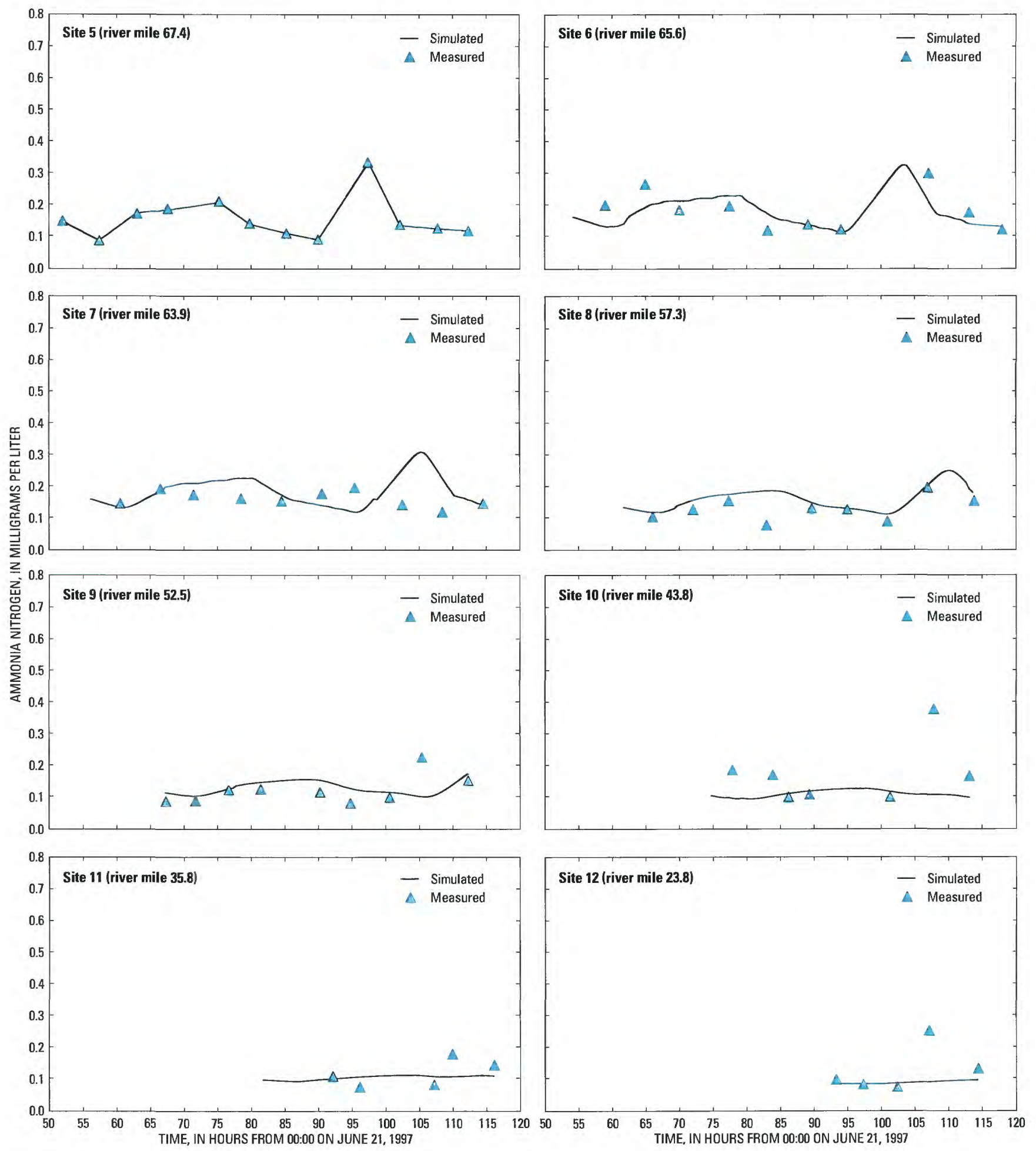

Figure 31. Simulated and measured ammonia nitrogen concentrations used in the Branched Lagrangian Transport Model (BLTM) calibration for eight locations on the Wateree River, S.C., June 23-25, 1997. 

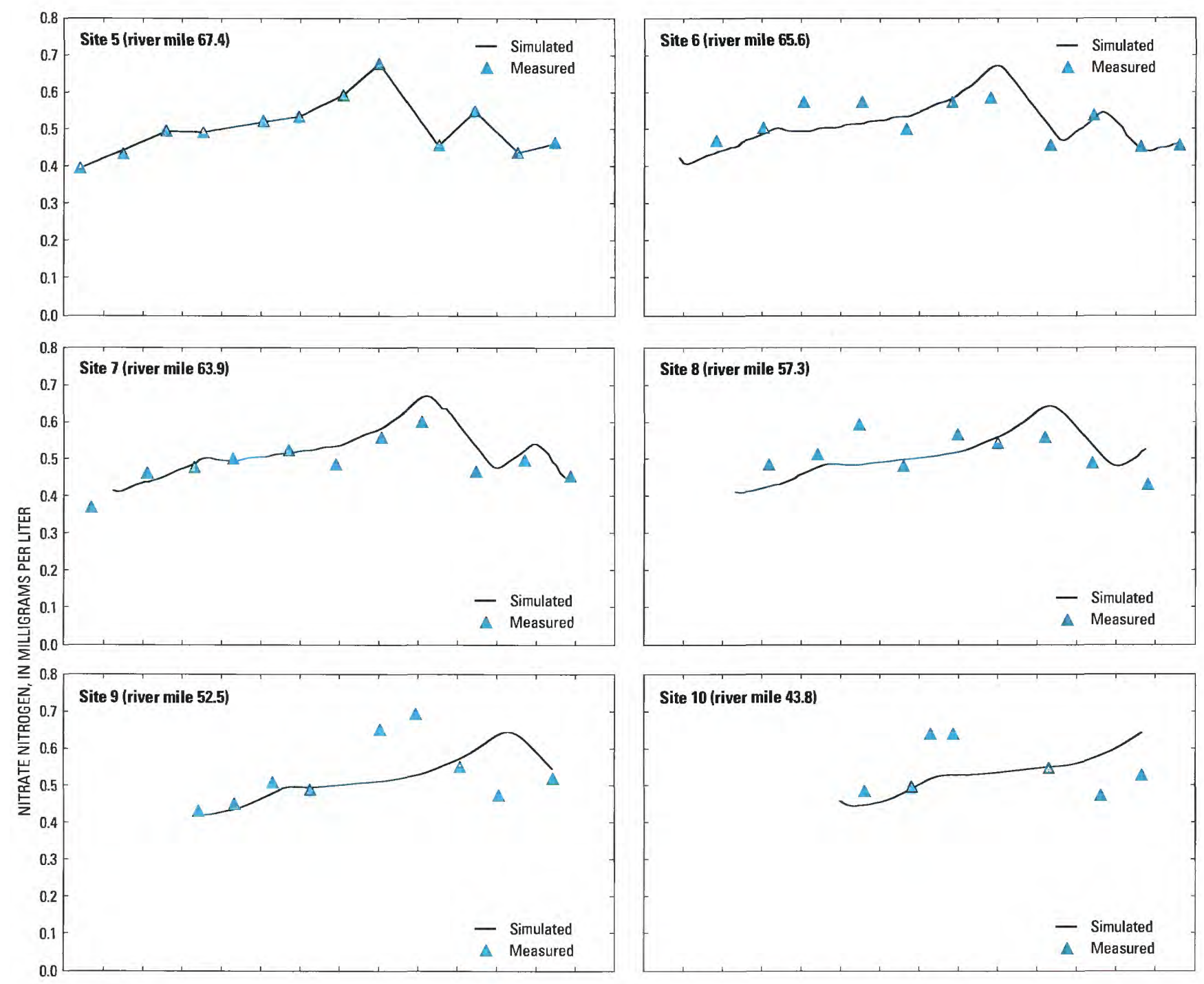

Site 10 (river mile 43.8)
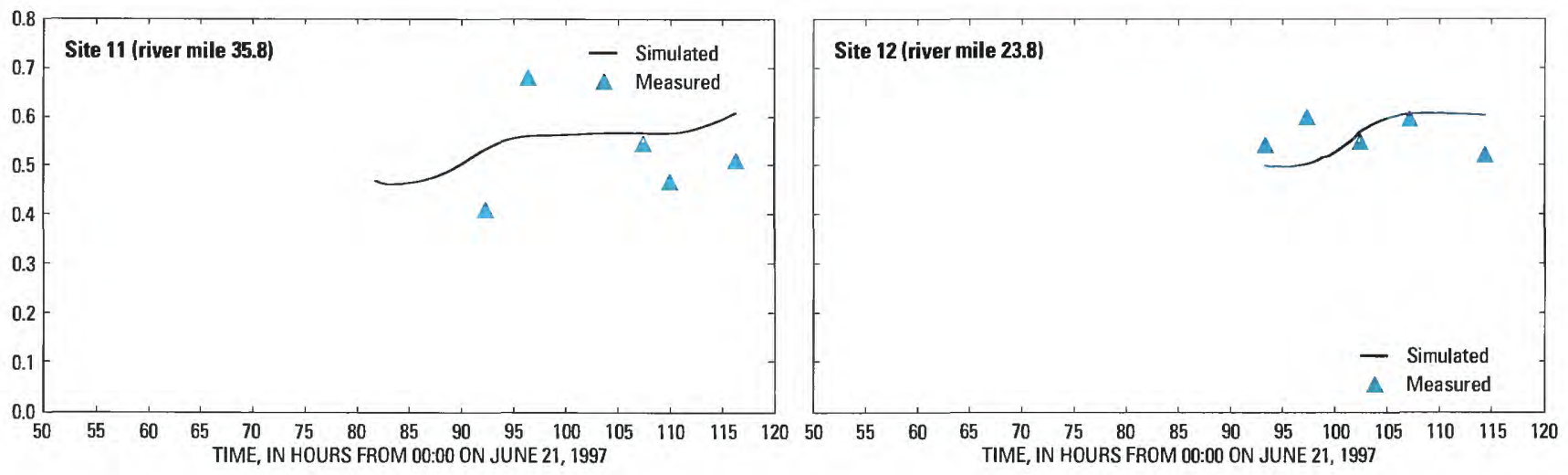

Figure 32. Simulated and measured nitrate nitrogen concentrations used in the Branched Lagrangian Transport Model (BLTM) calibration for eight locations on the Wateree River, S.C., June 23-25, 1997. 

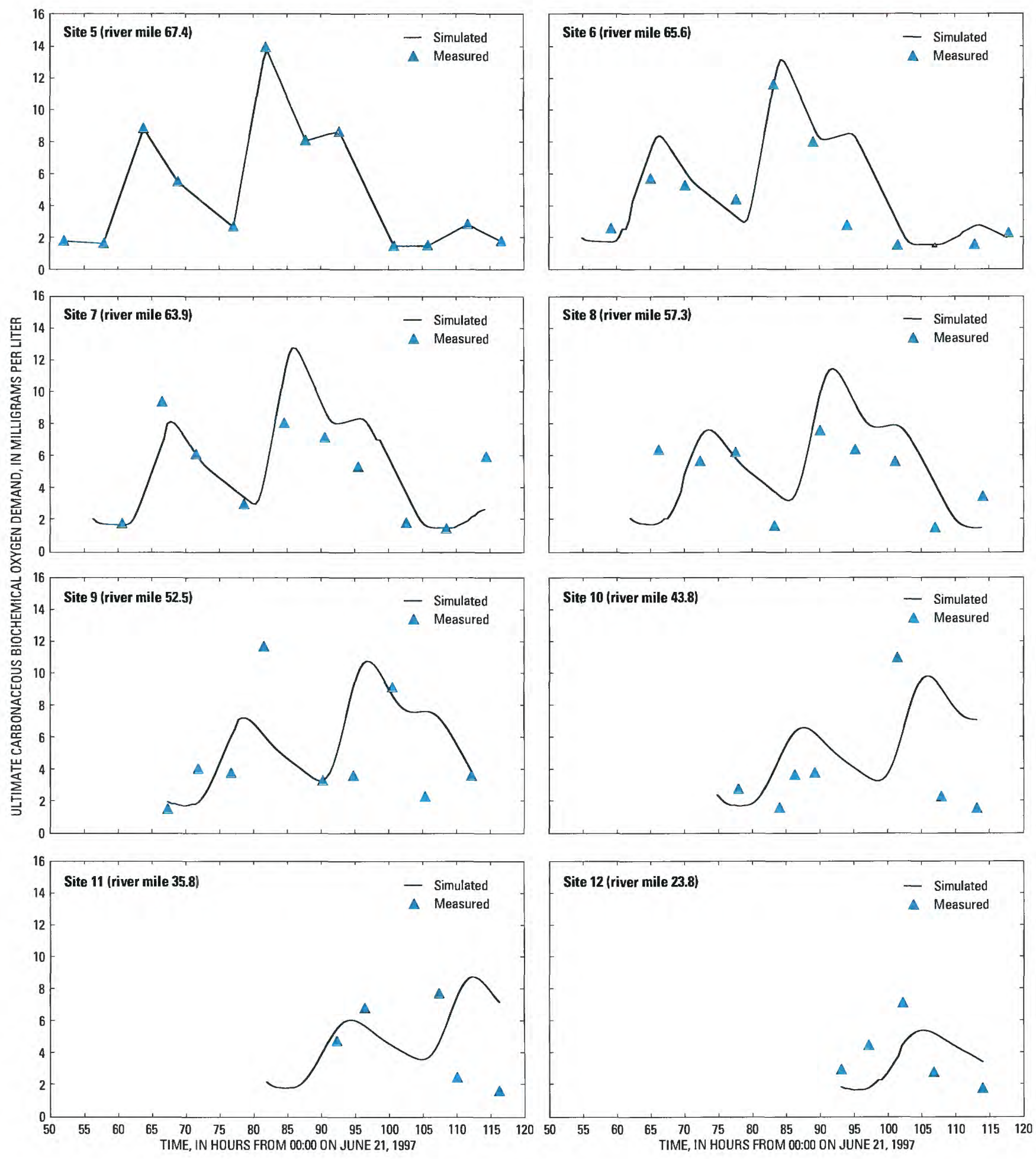

Figure 33. Simulated and measured ultimate carbonaceous biochemical oxygen demand concentrations used in the Branched Lagrangian Transport Model (BLTM) calibration for eight locations on the Wateree River, S.C., June 23-25, 1997. 

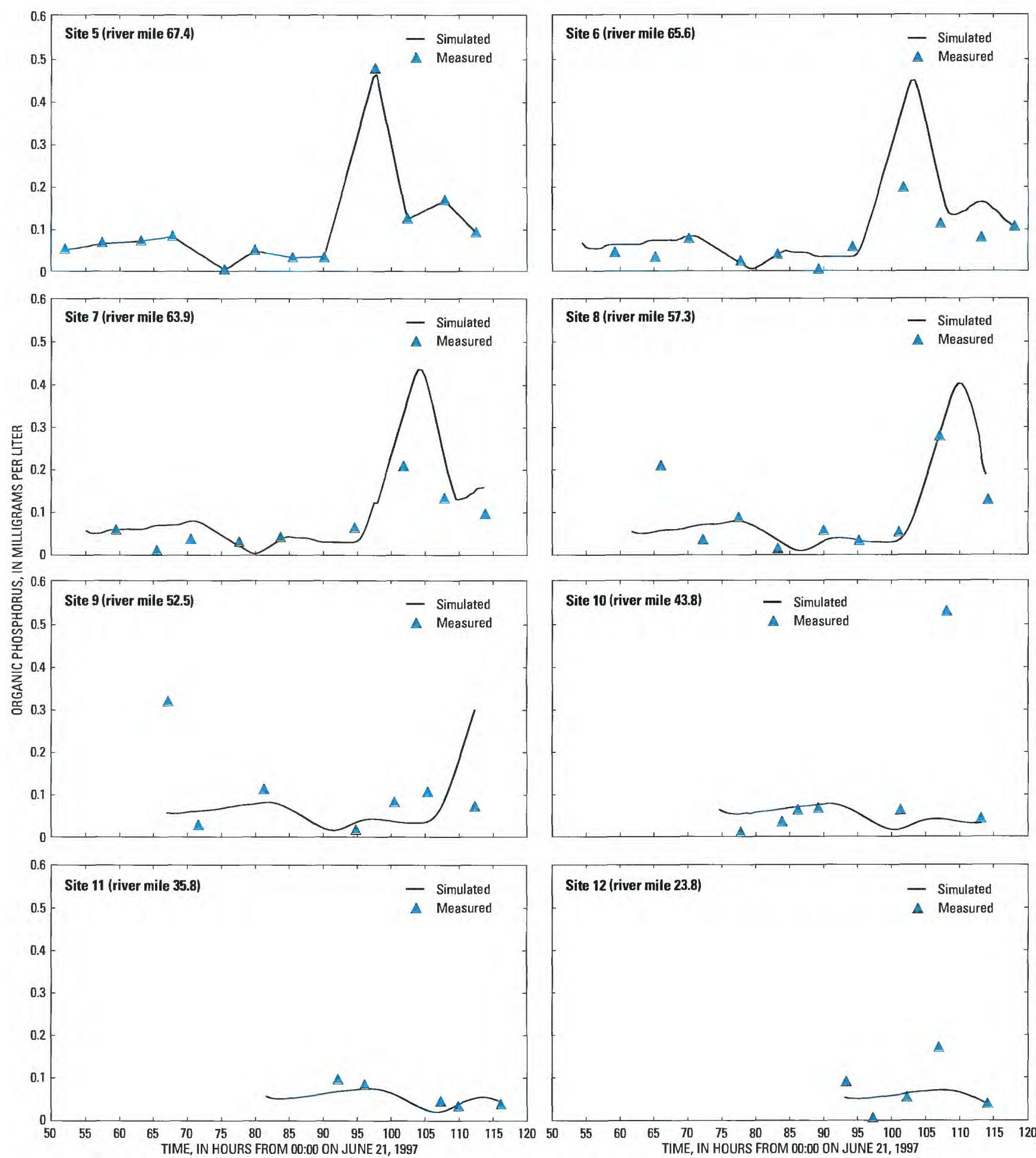

Site 12 (river mile 23.8)

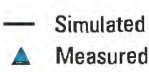

Figure 34. Simulated and measured organic phosphorus concentrations used in the Branched Lagrangian Transport Model (BLTM) calibration for eight locations on the Wateree River, S.C., June 23-25, 1997. 

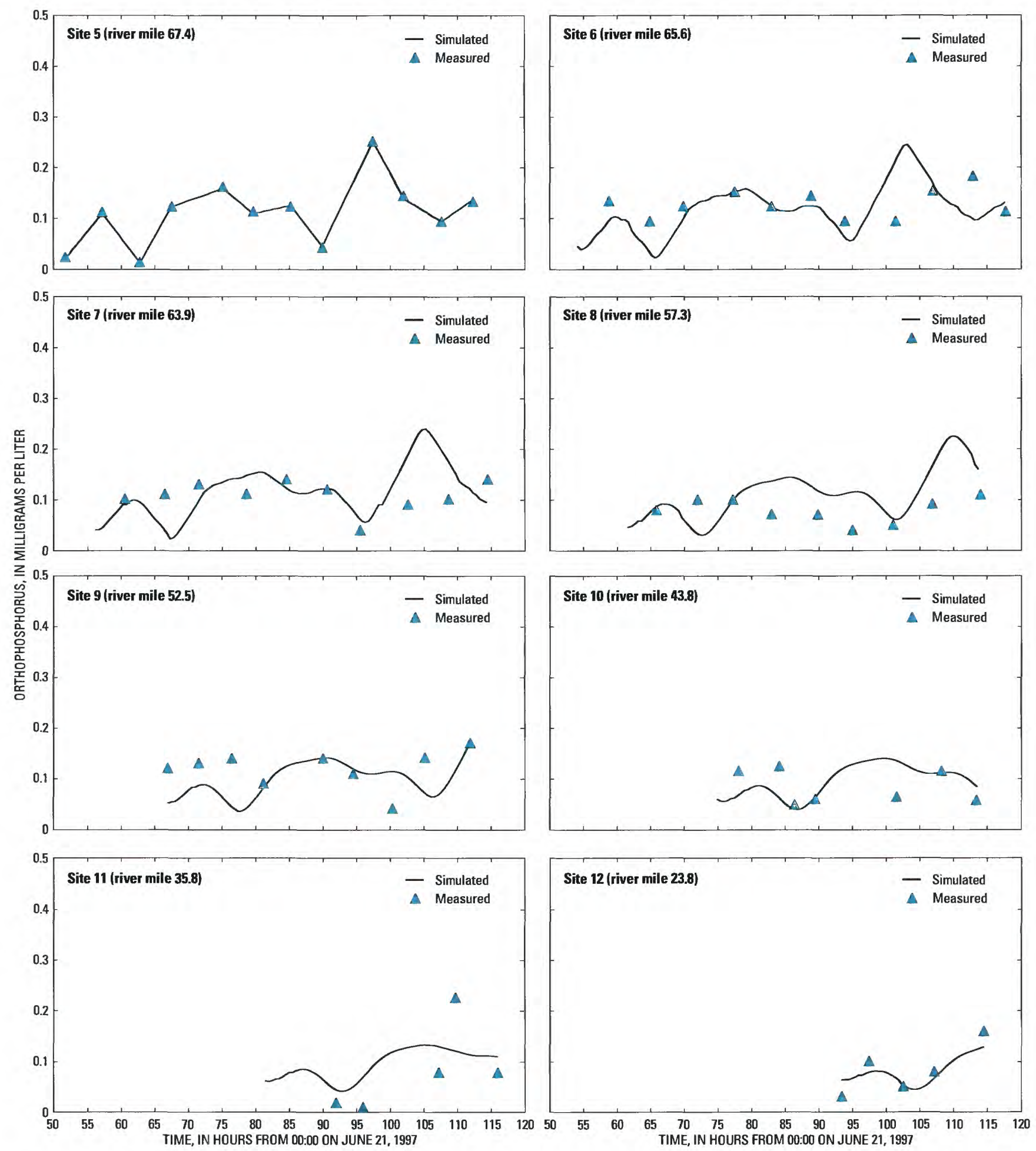

Figure 35. Simulated and measured orthophosphorus concentrations used in the Branched Lagrangian Transport Model (BLTM) calibration for eight locations on the Wateree River, S.C., June 23-25, 1997. 

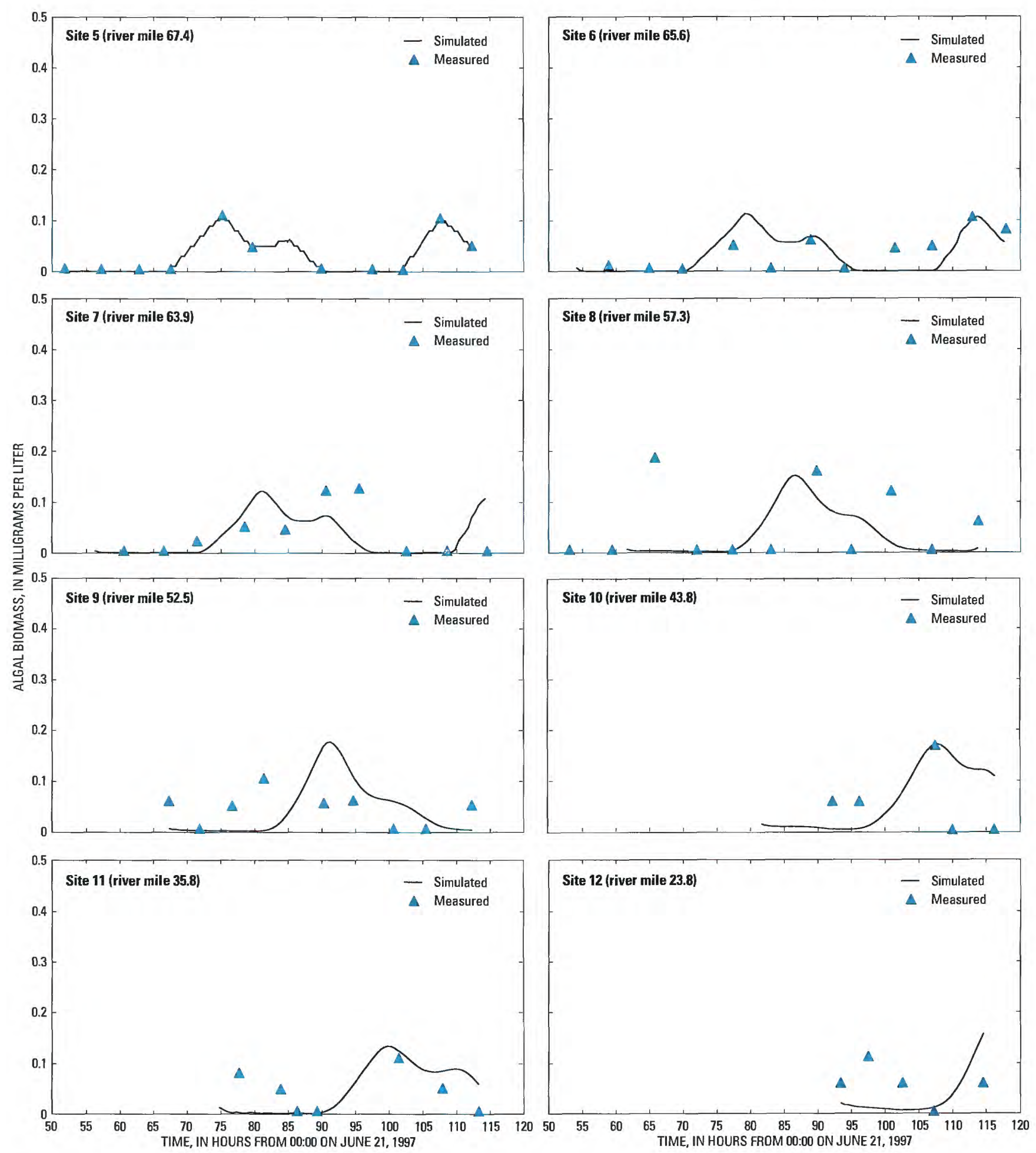

Figure 36. Simulated and measured algal biomass concentrations used in the Branched Lagrangian Transport Model (BLTM) calibration for eight locations on the Wateree River, S.C., June 23-25, 1997. 

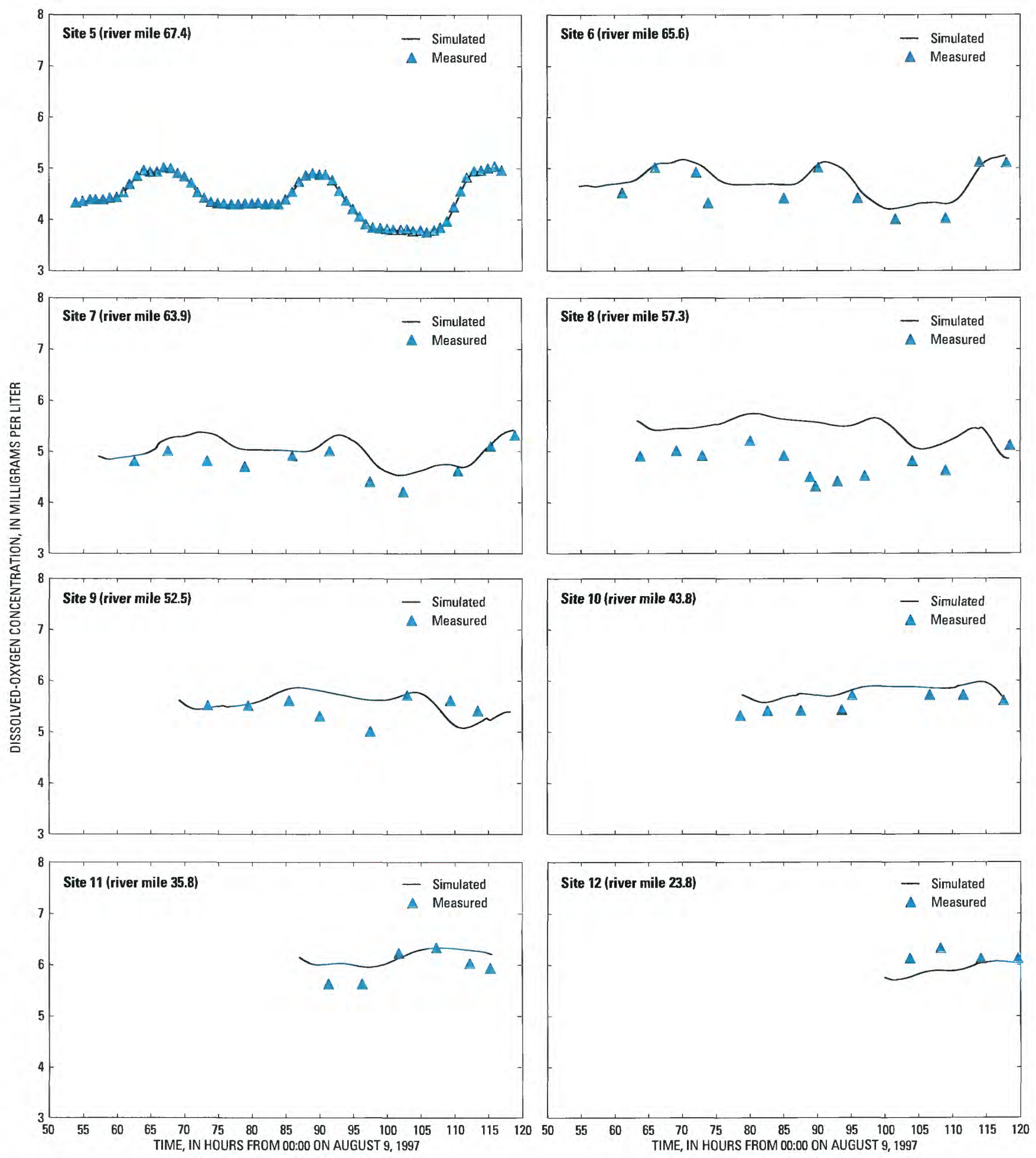

Figure 37. Simulated and measured dissolved-oxygen concentrations used in the Branched Lagrangian Transport Model (BLTM) validation for eight locations on the Wateree River, S.C., August 11-13, 1997. 

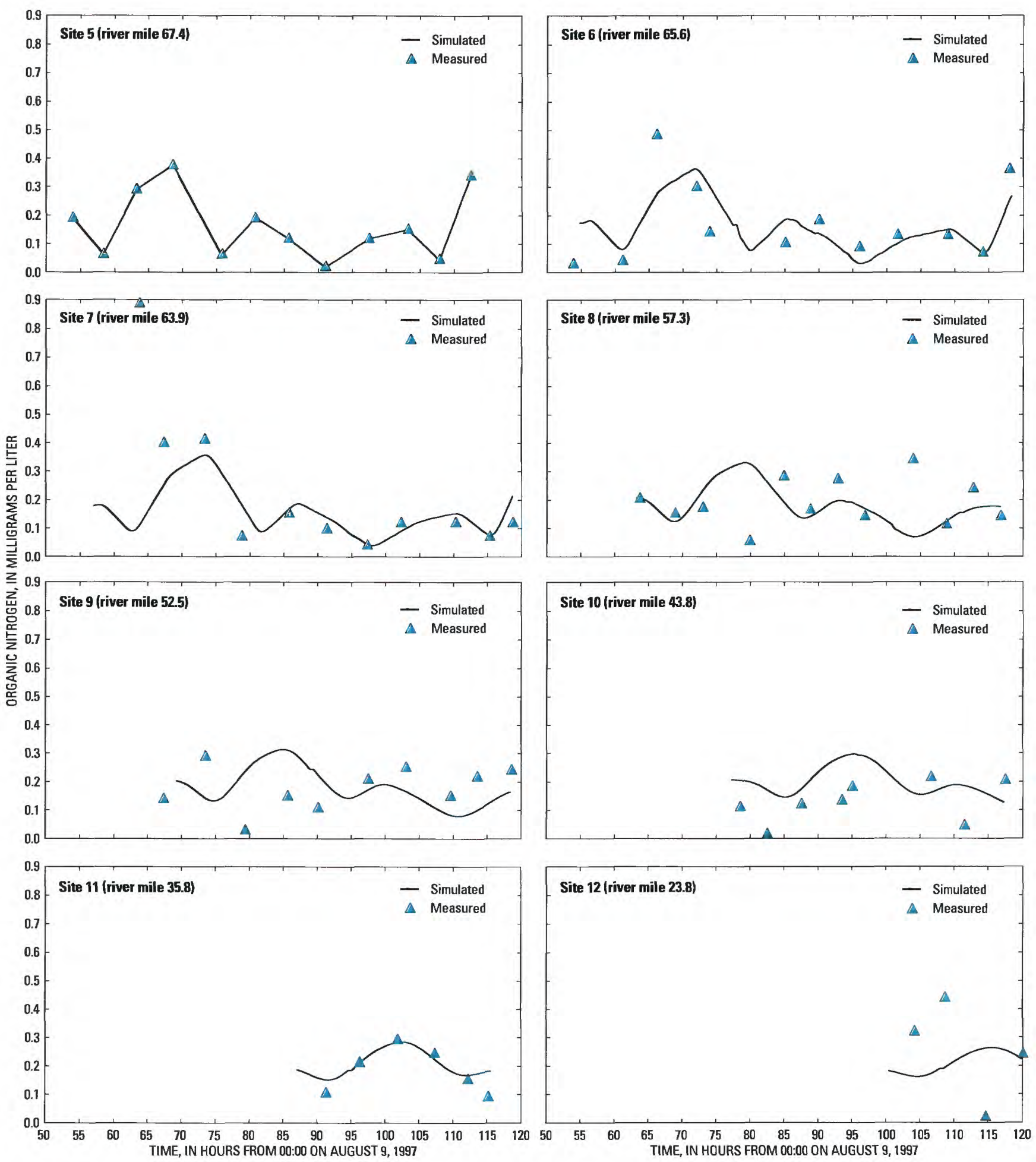

Figure 38. Simulated and measured organic nitrogen concentrations used in the Branched Lagrangian Transport Model (BLTM) validation for eight locations on the Wateree River, S.C., August 11-13, 1997. 

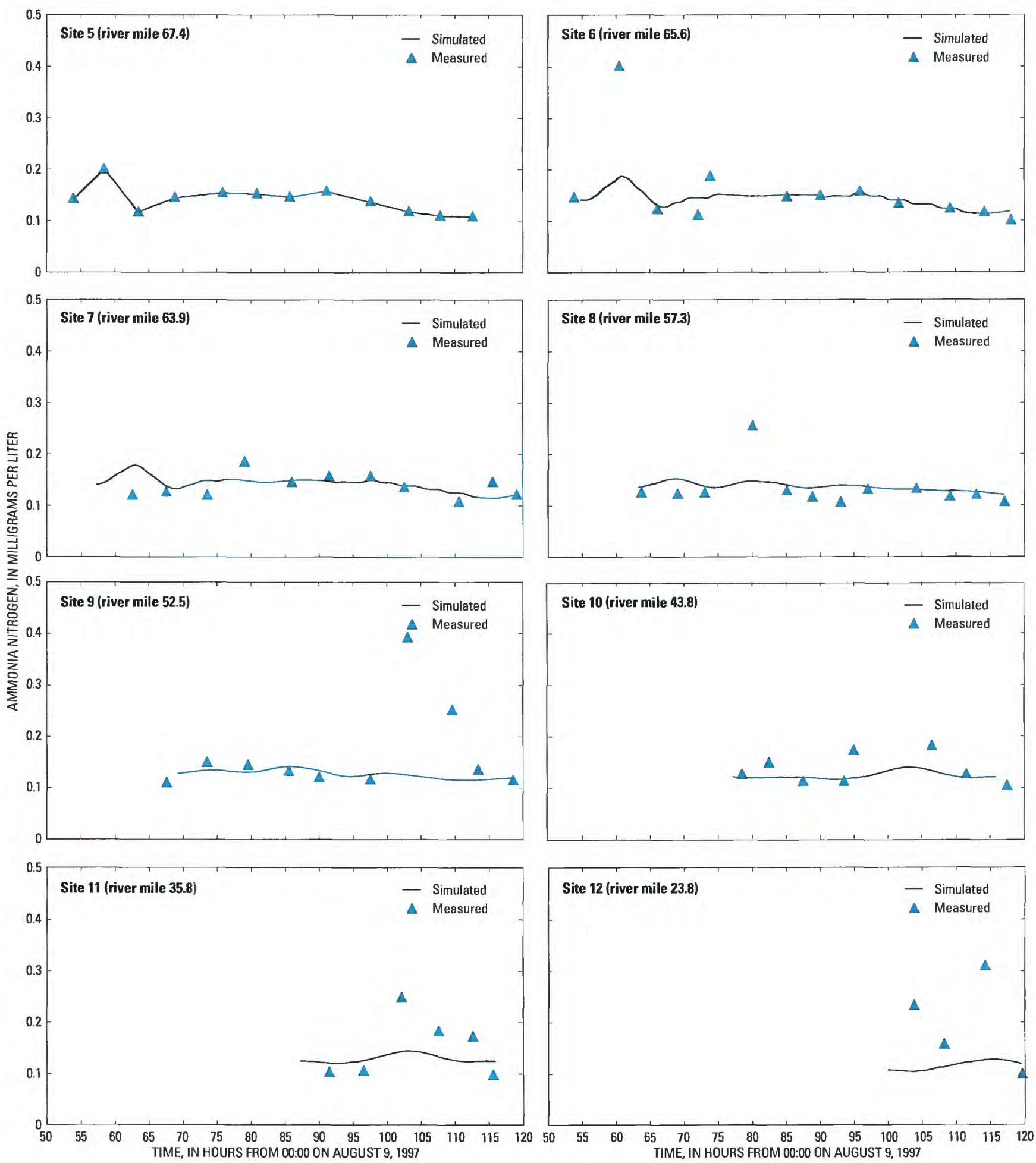

Figure 39. Simulated and measured ammonia nitrogen concentrations used in the Branched Lagrangian Transport Model (BLTM) validation for eight locations on the Wateree River, S.C., August 11-13, 1997. 

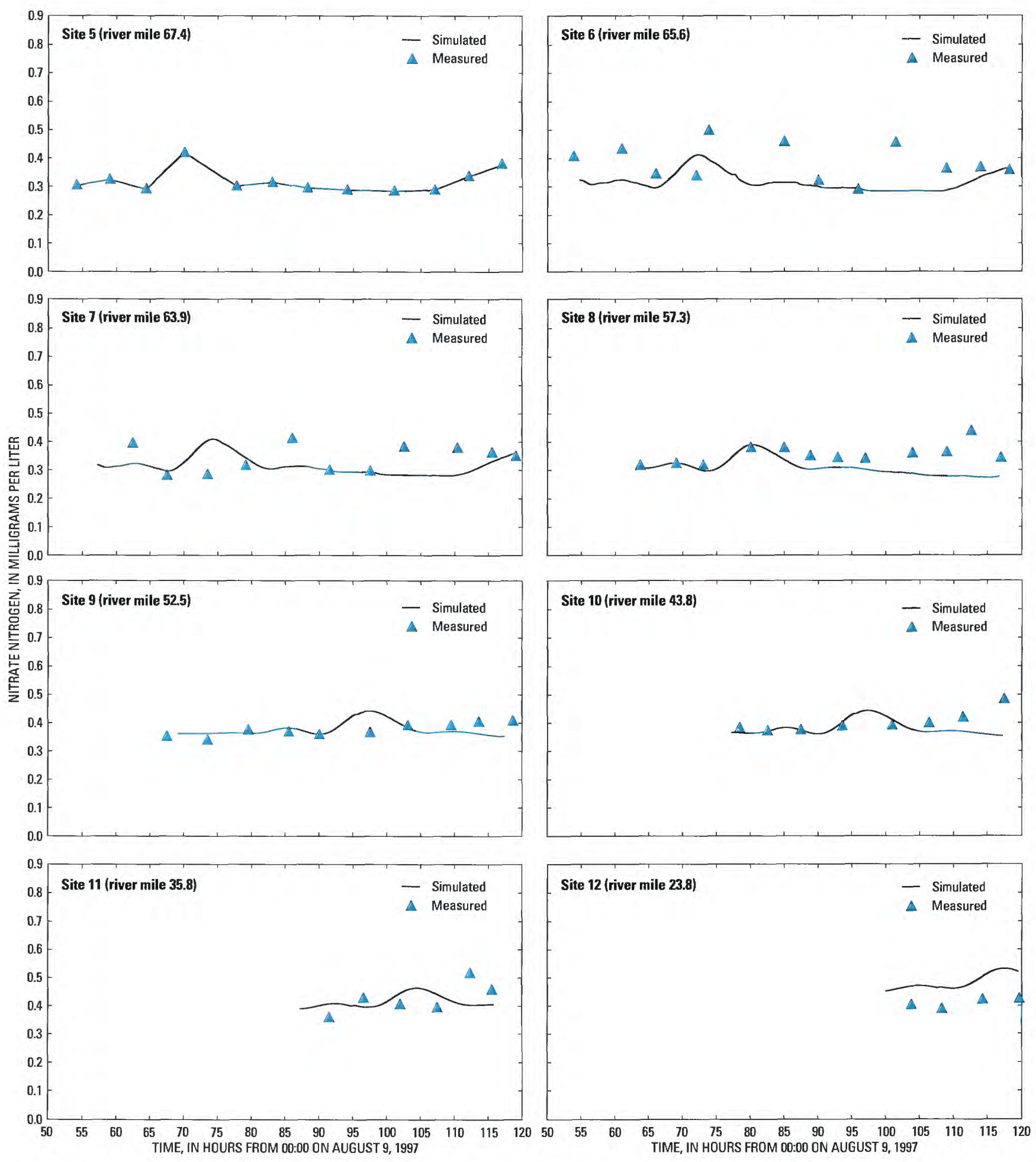

Figure 40. Simulated and measured nitrate nitrogen concentrations used in the Branched Lagrangian Transport Model (BLTM) validation for eight locations on the Wateree River, S.C., August 11-13, 1997. 

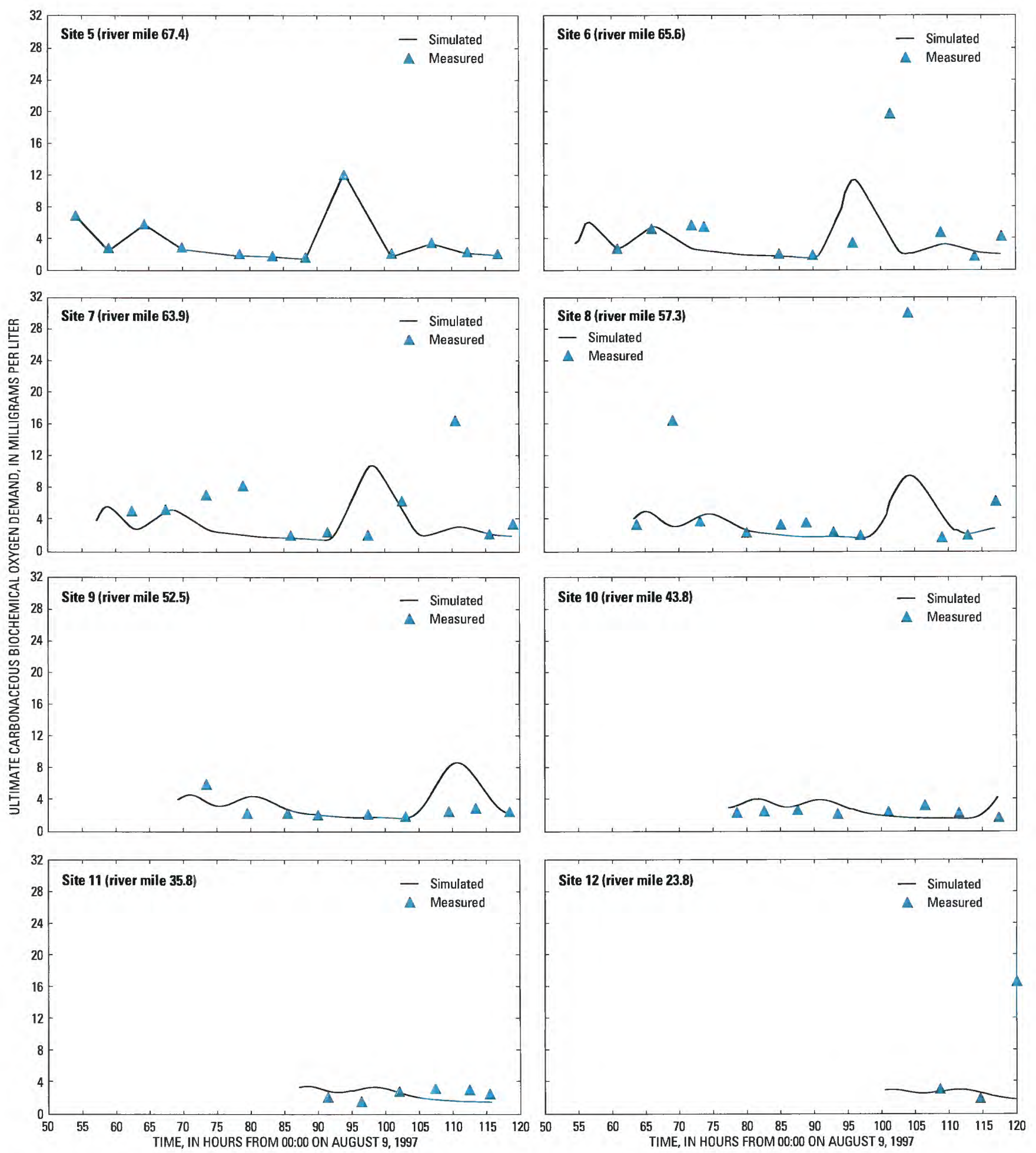

Figure 41. Simulated and measured ultimate carbonaceous biochemical oxygen demand concentrations used in the Branched Lagrangian Transport Model (BLTM) validation for eight locations on the Wateree River, S.C., August 11-13, 1997. 

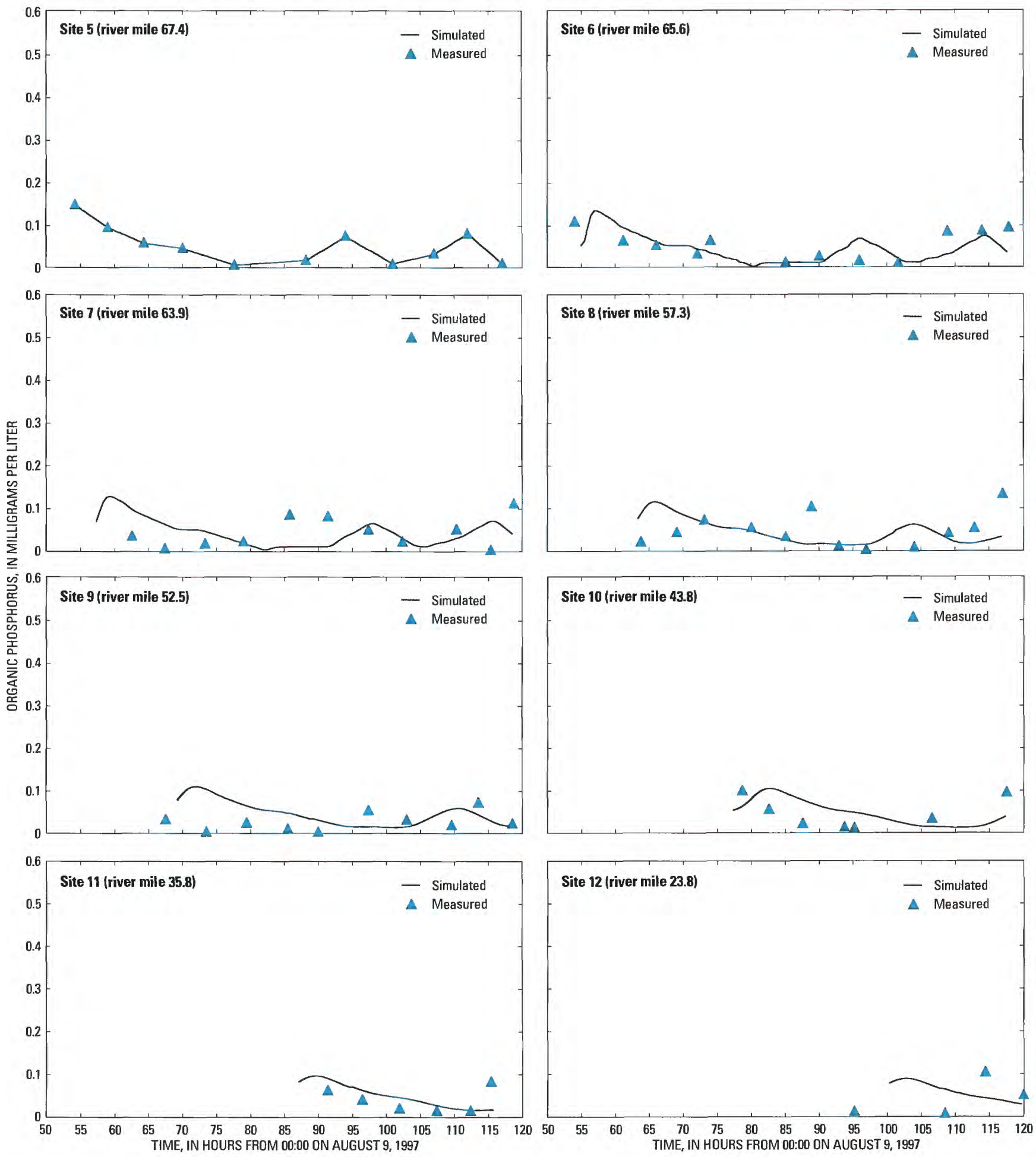

Figure 42. Simulated and measured organic phosphorus concentrations used in the Branched Lagrangian Transport Model (BLTM) validation for eight locations on the Wateree River, S.C., August 11-13, 1997. 

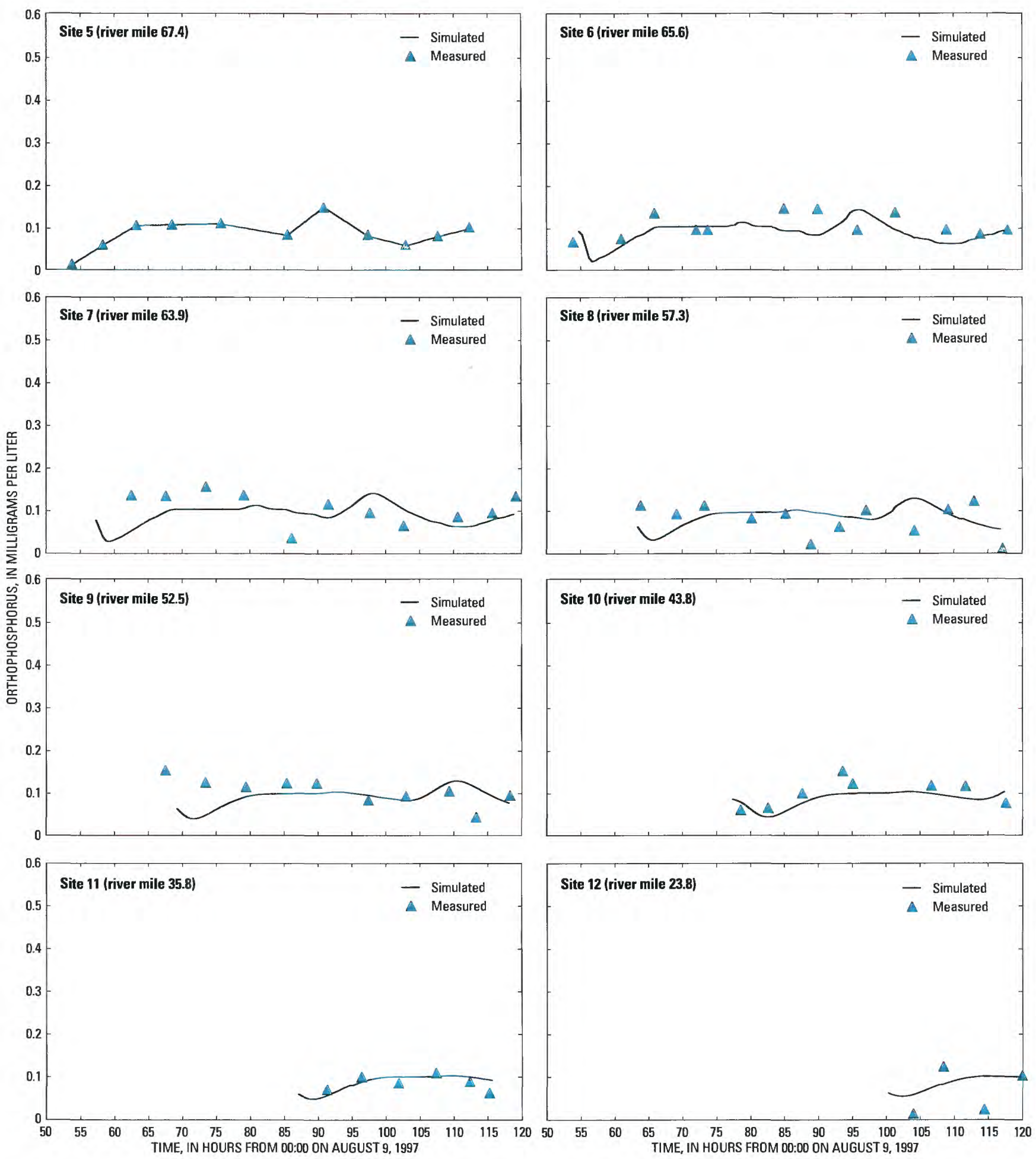

Figure 43. Simulated and measured orthophosphorus concentrations used in the Branched Lagrangian Transport Model (BLTM) validation for eight locations on the Wateree River, S.C., August 11-13, 1997. 

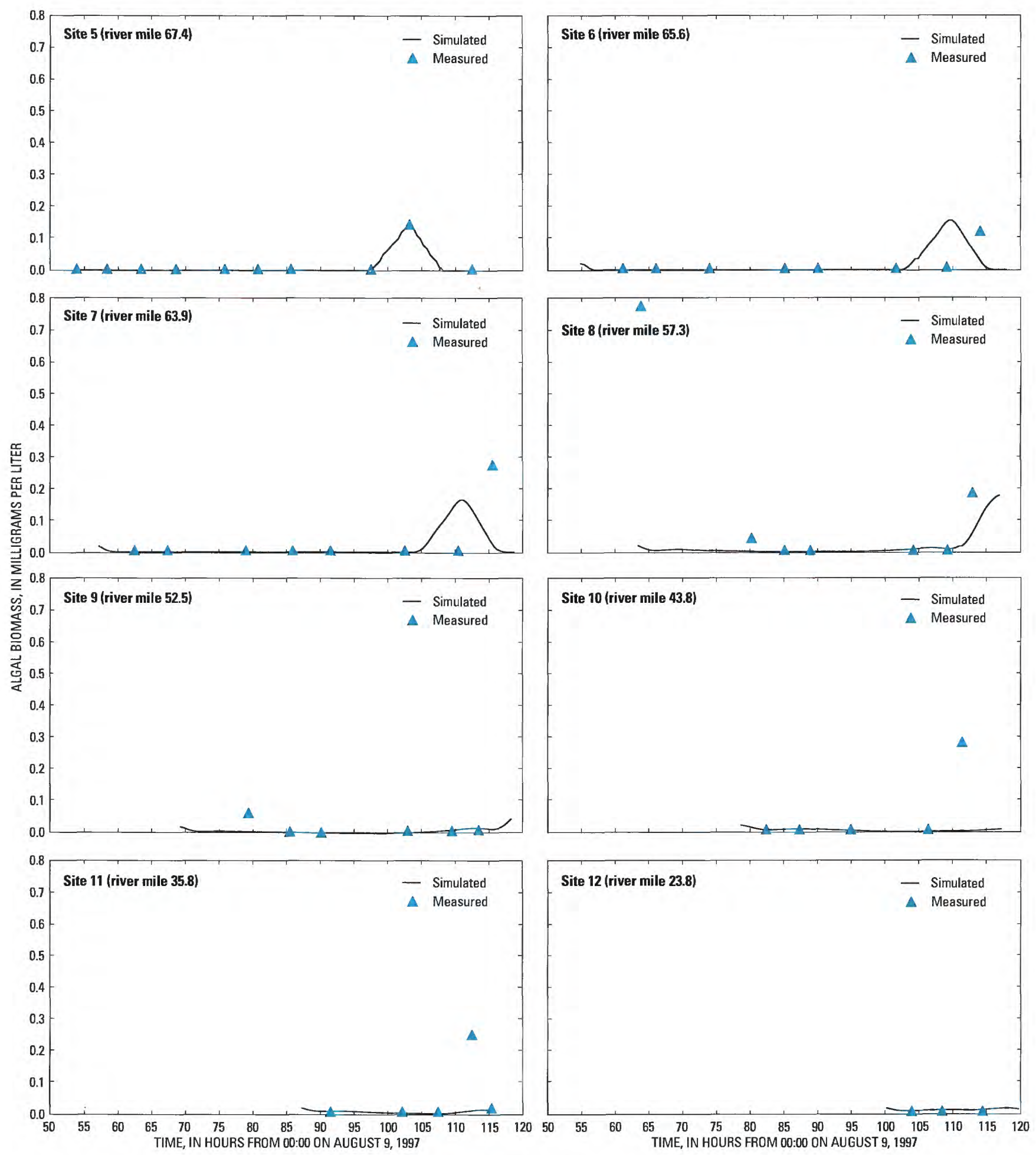

Figure 44. Simulated and measured algal biomass concentrations used in the Branched Lagrangian Transport Model (BLTM) validation for eight locations on the Wateree River, S.C., August 11-13, 1997. 
Table 14. Summary statistics for the simulated and measured concentrations used in the water-quality model calibration for seven locations on the Wateree River, S.C., June 23-25, 1997

[mg/L, milligram per liter; ${ }^{\circ} \mathrm{C}$, degrees Celsius]

\begin{tabular}{|c|c|c|c|c|c|c|c|}
\hline $\begin{array}{l}\text { Site no. } \\
\text { (fig. 9) }\end{array}$ & $\begin{array}{c}\text { Number of } \\
\text { observations }\end{array}$ & $\begin{array}{c}\text { Mean } \\
\text { measured }\end{array}$ & $\begin{array}{c}\text { Mean } \\
\text { simulated }\end{array}$ & $\begin{array}{l}\text { Root mean } \\
\text { square error }\end{array}$ & Mean error & $\begin{array}{c}\text { Minimum } \\
\text { absolute error }\end{array}$ & $\begin{array}{c}\text { Maximum } \\
\text { absolute error }\end{array}$ \\
\hline \multicolumn{8}{|c|}{ Dissolved oxygen (mg/L) } \\
\hline 6 & 11 & 4.60 & 4.90 & 0.51 & 0.30 & 0.01 & 1.36 \\
\hline 7 & 9 & 4.71 & 4.99 & .39 & .28 & .12 & .92 \\
\hline 8 & 9 & 5.29 & 5.31 & .11 & .02 & .00 & .24 \\
\hline 9 & 9 & 5.34 & 5.30 & .24 & -.05 & .03 & .46 \\
\hline 10 & 7 & 5.64 & 5.40 & .44 & -.24 & .06 & .84 \\
\hline 11 & 5 & 5.88 & 5.57 & .41 & -.31 & .16 & .64 \\
\hline 12 & 5 & 5.84 & 5.69 & .26 & -.15 & .12 & .38 \\
\hline \multicolumn{8}{|c|}{ Vater temperature $\left({ }^{\circ} \mathrm{C}\right)$} \\
\hline 6 & 11 & 24.3 & 24.3 & 0.29 & -0.01 & 0.00 & 0.60 \\
\hline 7 & 10 & 24.5 & 24.6 & .49 & .08 & .17 & 1.17 \\
\hline 8 & 9 & 24.9 & 25.0 & .23 & .06 & .00 & .40 \\
\hline 9 & 9 & 25.2 & 25.3 & .22 & .07 & .10 & .30 \\
\hline 10 & 7 & 25.8 & 26.0 & .26 & .19 & .00 & .40 \\
\hline 11 & 5 & 26.4 & 26.7 & .40 & .33 & .02 & .59 \\
\hline 12 & 5 & 26.4 & 26.5 & .20 & .18 & .10 & .30 \\
\hline \multicolumn{8}{|c|}{ Ultimate carbonaceous biochemical oxygen demand (mg/L) } \\
\hline 6 & 11 & 4.25 & 5.16 & 2.00 & 0.90 & 0.02 & 5.77 \\
\hline 7 & 10 & 5.04 & 5.47 & 2.08 & .43 & .02 & 3.28 \\
\hline 8 & 9 & 4.98 & 5.77 & 2.56 & .79 & .37 & 4.60 \\
\hline 9 & 9 & 4.77 & 5.48 & 3.45 & .71 & .10 & 6.22 \\
\hline 10 & 7 & 3.75 & 5.70 & 4.39 & 1.95 & 1.04 & 6.78 \\
\hline 11 & 5 & 4.59 & 6.05 & 3.64 & 1.46 & 1.07 & 5.42 \\
\hline 12 & 5 & 3.87 & 3.40 & 2.14 & -.47 & 1.18 & 2.63 \\
\hline \multicolumn{8}{|c|}{ Organic nitrogen (mg/L) } \\
\hline 6 & 11 & 0.17 & 0.09 & 0.15 & -0.08 & 0.01 & 0.36 \\
\hline 7 & 10 & .21 & .09 & .23 & -.12 & .00 & .64 \\
\hline 8 & 8 & .22 & .08 & .19 & -.14 & .04 & .29 \\
\hline 9 & 9 & .17 & .08 & .14 & -.09 & .01 & .23 \\
\hline 10 & 7 & .17 & .08 & .19 & -.09 & .00 & .42 \\
\hline 11 & 5 & .31 & .10 & .27 & -.20 & .02 & .48 \\
\hline 12 & 5 & .29 & .11 & .26 & -.18 & .06 & .46 \\
\hline \multicolumn{8}{|c|}{ Ammonia nitrogen $(\mathrm{mg} / \mathrm{L})$} \\
\hline 6 & 11 & 0.23 & 0.18 & 0.14 & -0.05 & 0.01 & 0.44 \\
\hline 7 & 10 & .16 & .18 & .06 & .02 & .00 & .11 \\
\hline 8 & 9 & .13 & .15 & .04 & .03 & .01 & .10 \\
\hline 9 & 9 & .12 & .13 & .05 & .01 & .01 & .12 \\
\hline 10 & 7 & .17 & .10 & .11 & -.07 & .01 & .28 \\
\hline 11 & 5 & .11 & .10 & .04 & -.01 & .00 & .06 \\
\hline 12 & 5 & .12 & .08 & .08 & -.04 & .01 & .16 \\
\hline \multicolumn{8}{|c|}{ Nitrite plus nitrate nitrogen (mg/L) } \\
\hline 6 & 11 & 0.52 & 0.51 & 0.04 & -0.00 & 0.00 & 0.08 \\
\hline 7 & 10 & .50 & .52 & .03 & .02 & .00 & .06 \\
\hline 8 & 9 & .51 & .52 & .06 & .00 & .02 & .11 \\
\hline 9 & 9 & .53 & .51 & .09 & -.02 & .01 & .17 \\
\hline 10 & 7 & .54 & .54 & .09 & -.01 & .00 & .13 \\
\hline 11 & 5 & .52 & .57 & .10 & .05 & .02 & .13 \\
\hline 12 & 5 & .56 & .56 & .06 & -.00 & .02 & .09 \\
\hline
\end{tabular}


Table 14. Summary statistics for the simulated and measured concentrations used in the water-quality model calibration for seven locations on the Wateree River, S.C., June 23-25, 1997-Continued

[mg/L, milligram per liter; ${ }^{\circ} \mathrm{C}$, degrees Celsius]

\begin{tabular}{|c|c|c|c|c|c|c|c|}
\hline $\begin{array}{l}\text { Site no. } \\
\text { (fig. 9) }\end{array}$ & $\begin{array}{c}\text { Number of } \\
\text { observations }\end{array}$ & $\begin{array}{c}\text { Mean } \\
\text { measured }\end{array}$ & $\begin{array}{c}\text { Mean } \\
\text { simulated }\end{array}$ & $\begin{array}{l}\text { Root mean } \\
\text { square error }\end{array}$ & Mean error & $\begin{array}{c}\text { Minimum } \\
\text { absolute error }\end{array}$ & $\begin{array}{c}\text { Maximum } \\
\text { absolute error }\end{array}$ \\
\hline \multicolumn{8}{|c|}{ Algal biomass (mg/L) } \\
\hline 6 & 11 & 0.04 & 0.04 & 0.03 & -0.00 & 0.00 & 0.06 \\
\hline 7 & 10 & .04 & .04 & .05 & -.00 & .00 & .11 \\
\hline 8 & 9 & .06 & .03 & .08 & -.03 & .00 & .18 \\
\hline 9 & 9 & .04 & .04 & .06 & -.00 & .00 & .12 \\
\hline 10 & 7 & .04 & .04 & .04 & -.00 & .00 & .08 \\
\hline 11 & 5 & .06 & .09 & .09 & .03 & .00 & .14 \\
\hline 12 & 5 & .06 & .04 & .07 & -.01 & .01 & .11 \\
\hline \multicolumn{8}{|c|}{ Organic phosphorus (mg/L) } \\
\hline 6 & 11 & 0.07 & 0.11 & 0.07 & 0.04 & 0.00 & 0.19 \\
\hline 7 & 10 & .07 & .10 & .06 & .04 & .00 & .12 \\
\hline 8 & 9 & .10 & .09 & .06 & -.01 & .00 & .15 \\
\hline 9 & 7 & .10 & .09 & .14 & -.01 & .02 & .26 \\
\hline 10 & 6 & .11 & .05 & .20 & -.07 & .01 & .49 \\
\hline 11 & 5 & .06 & .05 & .02 & -.01 & .00 & .03 \\
\hline 12 & 5 & .07 & .06 & .05 & -.02 & .00 & .10 \\
\hline \multicolumn{8}{|c|}{ Orthophosphorus (mg/L) } \\
\hline 6 & 11 & 0.12 & 0.12 & 0.05 & -0.01 & 0.00 & 0.12 \\
\hline 7 & 10 & .11 & .11 & .05 & .01 & .00 & .10 \\
\hline 8 & 9 & .08 & .11 & .05 & .03 & .00 & .08 \\
\hline 9 & 9 & .12 & .10 & .05 & -.02 & .00 & .09 \\
\hline 10 & 7 & .08 & .08 & .04 & -.00 & .00 & .07 \\
\hline 11 & 5 & .08 & .10 & .06 & .01 & .02 & .11 \\
\hline 12 & 5 & .08 & .08 & .02 & -.00 & .00 & .04 \\
\hline
\end{tabular}


Table 15. Summary statistics for the simulated and measured concentrations used in the water-quality model validation for seven locations on the Wateree River, S.C., August 11-13, 1997

[mg/L, milligram per liter; ${ }^{\circ} \mathrm{C}$, degrees Celsius]

\begin{tabular}{|c|c|c|c|c|c|c|c|}
\hline $\begin{array}{l}\text { Site no. } \\
\text { (fig. 9) }\end{array}$ & $\begin{array}{c}\text { Number of } \\
\text { observations }\end{array}$ & $\begin{array}{c}\text { Mean } \\
\text { measured }\end{array}$ & $\begin{array}{c}\text { Mean } \\
\text { simulated }\end{array}$ & $\begin{array}{c}\text { Root mean } \\
\text { square error }\end{array}$ & Mean error & $\begin{array}{c}\text { Minimum } \\
\text { absolute error }\end{array}$ & $\begin{array}{c}\text { Maximum } \\
\text { absolute error }\end{array}$ \\
\hline \multicolumn{8}{|c|}{ Dissolved oxygen $(\mathrm{mg} / \mathrm{L})$} \\
\hline 6 & 11 & 4.61 & 4.77 & 0.23 & 0.16 & 0.06 & 0.55 \\
\hline 7 & 11 & 4.80 & 5.02 & .27 & .22 & .04 & .53 \\
\hline 8 & 11 & 4.80 & 5.48 & .74 & .68 & .18 & 1.19 \\
\hline 9 & 8 & 5.45 & 5.60 & .38 & .15 & .07 & .70 \\
\hline 10 & 8 & 5.52 & 5.84 & .35 & .31 & .02 & .60 \\
\hline 11 & 6 & 5.93 & 6.20 & .32 & .27 & .04 & .46 \\
\hline 12 & 4 & 6.15 & 6.03 & .19 & -.12 & .05 & .32 \\
\hline \multicolumn{8}{|c|}{ Water temperature $\left({ }^{\circ} \mathrm{C}\right)$} \\
\hline 6 & 11 & 27.3 & 27.4 & 0.29 & 0.14 & 0.00 & 0.65 \\
\hline 7 & 11 & 27.4 & 27.4 & .24 & -.02 & .00 & .60 \\
\hline 8 & 10 & 27.3 & 27.2 & .47 & -.08 & .10 & .90 \\
\hline 9 & 8 & 27.6 & 27.4 & .50 & -.18 & .10 & .95 \\
\hline 10 & 8 & 27.6 & 27.6 & .66 & -.02 & .05 & .95 \\
\hline 11 & 6 & 28.2 & 28.3 & .97 & .08 & .05 & 1.35 \\
\hline 12 & 4 & 28.2 & 28.2 & .36 & .00 & .05 & .50 \\
\hline \multicolumn{8}{|c|}{ Ultimate carbonaceous biochemical oxygen demand (mg/L) } \\
\hline 6 & 11 & 5.07 & 3.62 & 5.44 & -1.45 & 0.16 & 15.4 \\
\hline 7 & 11 & 5.50 & 3.64 & 5.35 & -1.85 & .06 & 13.4 \\
\hline 8 & 12 & 6.41 & 3.49 & 7.20 & -2.93 & .24 & 20.5 \\
\hline 9 & 9 & 2.62 & 3.72 & 2.53 & 1.11 & .10 & 5.70 \\
\hline 10 & 8 & 2.34 & 2.93 & 1.45 & .59 & .50 & 2.90 \\
\hline 11 & 6 & 2.52 & 2.38 & 1.16 & -.14 & .04 & 1.78 \\
\hline 12 & 3 & 7.10 & 2.39 & 8.51 & -4.71 & .24 & 14.7 \\
\hline \multicolumn{8}{|c|}{ Organic nitrogen $(\mathrm{m} g / \mathrm{L})$} \\
\hline 6 & 11 & 0.18 & 0.18 & 0.10 & -0.01 & .00 & .21 \\
\hline 7 & 11 & .23 & .16 & .25 & -.06 & .00 & .79 \\
\hline 8 & 12 & .19 & .17 & .12 & -.01 & .00 & .27 \\
\hline 9 & 9 & .18 & .18 & .12 & .00 & .04 & .21 \\
\hline 10 & 8 & .13 & .20 & .11 & .07 & .05 & .16 \\
\hline 11 & 6 & .18 & .20 & .04 & .02 & .00 & .09 \\
\hline 12 & 4 & .26 & .21 & .19 & -.05 & .02 & .25 \\
\hline \multicolumn{8}{|c|}{ Ammonia nitrogen (mg/L) } \\
\hline 6 & 11 & 0.16 & 0.14 & 0.07 & -0.02 & 0.00 & 0.22 \\
\hline 7 & 11 & .14 & .14 & .03 & .00 & .00 & .06 \\
\hline 8 & 12 & .13 & .13 & .03 & .00 & .00 & .11 \\
\hline 9 & 9 & .17 & .13 & .10 & -.04 & .00 & .27 \\
\hline 10 & 8 & .14 & .12 & .03 & -.02 & .00 & .07 \\
\hline 11 & 6 & .15 & .13 & .05 & -.02 & .02 & .10 \\
\hline 12 & 4 & .20 & .12 & .11 & -.08 & .02 & .18 \\
\hline \multicolumn{8}{|c|}{ Nitrite plus nitrate nitrogen ( $\mathrm{mg} / \mathrm{L})$} \\
\hline 6 & 11 & 0.38 & 0.32 & 0.09 & -0.06 & 0.01 & 0.17 \\
\hline 7 & 11 & .34 & .32 & .07 & -.02 & .00 & .12 \\
\hline 8 & 12 & .35 & .31 & .06 & -.05 & .00 & .16 \\
\hline 9 & 9 & .37 & .33 & .07 & -.05 & .00 & .11 \\
\hline 10 & 8 & .40 & .37 & .05 & -.02 & .00 & .13 \\
\hline 11 & 6 & .42 & .42 & .06 & -.01 & .03 & .11 \\
\hline 12 & 4 & .41 & .49 & .08 & .08 & .07 & .10 \\
\hline
\end{tabular}


Table 15. Summary statistics for the simulated and measured concentrations used in the water-quality model validation for seven locations on the Wateree River, S.C., August 11-13, 1997-Continued

[mg/L, milligram per liter; ${ }^{\circ} \mathrm{C}$, degrees Celsius]

\begin{tabular}{|c|c|c|c|c|c|c|c|}
\hline $\begin{array}{l}\text { Site no. } \\
\text { (fig. 9) }\end{array}$ & $\begin{array}{c}\text { Number of } \\
\text { observations }\end{array}$ & $\begin{array}{c}\text { Mean } \\
\text { measured }\end{array}$ & $\begin{array}{c}\text { Mean } \\
\text { simulated }\end{array}$ & $\begin{array}{l}\text { Root mean } \\
\text { square error }\end{array}$ & Mean error & $\begin{array}{c}\text { Minimum } \\
\text { absolute error }\end{array}$ & $\begin{array}{c}\text { Maximum } \\
\text { absolute error }\end{array}$ \\
\hline \multicolumn{8}{|c|}{ Algal biomass (mg/L) } \\
\hline 6 & 8 & 0.02 & 0.02 & 0.06 & 0.00 & 0.00 & 0.14 \\
\hline 7 & 8 & .04 & .02 & .10 & -.01 & .00 & .24 \\
\hline 8 & 7 & .15 & .01 & .29 & -.13 & .00 & .76 \\
\hline 9 & 6 & .02 & .01 & .02 & -.01 & .00 & .06 \\
\hline 10 & 5 & .06 & .01 & .12 & -.06 & .00 & .28 \\
\hline 11 & 5 & .06 & .01 & .11 & -.05 & .00 & .24 \\
\hline 12 & 3 & .01 & .01 & .01 & .01 & .00 & .01 \\
\hline \multicolumn{8}{|c|}{ Organic phosphorus (mg/L) } \\
\hline 6 & 11 & 0.05 & 0.04 & 0.03 & $-0,00$ & 0.00 & 0.06 \\
\hline 7 & 11 & .04 & .04 & .05 & .00 & .00 & .07 \\
\hline 8 & 12 & .05 & .04 & .05 & -.01 & .00 & .10 \\
\hline 9 & 9 & .02 & .04 & .05 & .02 & .00 & .10 \\
\hline 10 & 7 & .05 & .06 & .04 & .01 & .02 & .06 \\
\hline 11 & 6 & .04 & .04 & .03 & .01 & .00 & .07 \\
\hline 12 & 3 & .05 & .05 & .05 & -.01 & .02 & .06 \\
\hline \multicolumn{8}{|c|}{ Orthophosphorus (mg/L) } \\
\hline 6 & 11 & 0.10 & 0.09 & 0.03 & -0.01 & 0.00 & 0.06 \\
\hline 7 & 11 & .10 & .09 & .05 & -.01 & .02 & .08 \\
\hline 8 & 12 & .08 & .08 & .04 & .01 & .01 & .08 \\
\hline 9 & 9 & .10 & .09 & .04 & -.01 & .01 & .07 \\
\hline 10 & 8 & .10 & .08 & .03 & -.01 & .02 & .05 \\
\hline 11 & 6 & .08 & .09 & .02 & .01 & .01 & .03 \\
\hline 12 & 4 & .06 & .08 & .05 & .02 & .00 & .08 \\
\hline
\end{tabular}


River is bounded by swamps and farm land, there is potential for decaying organic material to be washed into the river during high flows when water is stored in small creeks and depressions in the swamps. On June 15 and 16, 1997, streamflow at USGS station 02148000 reached a peak of approximately $12,000 \mathrm{ft}^{3} / \mathrm{s}$ as a result of significant rainfall. On June 22, 1997, at $2200 \mathrm{EST}$, a peak of approximately $8,200 \mathrm{ft}^{3} / \mathrm{s}$ was recorded at station 02148000 . Sampling for the calibration period began during the predawn hours on June 23, 1997, when flows at the dam were held steady at approximately $2,700 \mathrm{ft}^{3} / \mathrm{s}$ (fig. 19). Consequently, water that was stored in small depressions and creeks in the watershed would have been draining during the sampling period.

The calibration and validation graphs of the simulated data indicate that the boundary data exert a significant influence on the model simulations. The general shape of the boundary data is propagated downstream and influenced by dispersion, decay, and oxidation of the different constituents. However, at no sampling location does it appear that the simulated shape was significantly altered, indicating less of an influence by the point-source and tributary boundary data for these simulated conditions.

Some of the outliers noted in the measured data may be attributable to mixing in the river. The waterquality samples were collected as discrete samples as near to the center of flow as possible. However, as noted in the graphs of the time-of-travel response curves, significant mixing was still occurring at approximately $10 \mathrm{mi}$ downstream from the release site during the June 1997 sampling period (figs. 22, 23).

Consequently, the samples collected at locations close to points of mixing could contain different concentrations of certain constituents as compared to a composite sample taken at several locations across the channel. In future studies and when analyzing and using STORET data, assumptions of complete mixing should be given more consideration.

\section{Dissolved-Oxygen Sensitivity Analysis}

Sensitivity of the BLTM water-quality model to changes in model input was analyzed by evaluating the mean DO concentration of the Wateree River at site 9 for August 12, 1997 (table 16). Site 9 was chosen because it is located downstream from all effluent dischargers, approximately halfway between the upstream and downstream boundary, and downstream from the critical or minimum DO concentrations. August 12, 1997, was chosen as the 24-hour evaluation period to give the upstream boundary data time to reach this location. Three groups of model inputs were evaluated: model input variables (including rate constants and settling rates), meteorologic input data, and boundary input data of water-quality constituent concentrations. The validation simulation for site 9 was used to compute a base value to compare with the simulated DO concentrations for the sensitivity analysis simulations. Test values for model input data were increased by approximately 35 percent while all other variables were unchanged. Time-dependent inputs to the model, such as the meteorologic input data and boundary constituent concentrations, were changed for each simulation time step. In addition, because the flows for the sampling period were held constant, a flow sensitivity analysis also was made. The flows at the upstream boundary for the June and August sampling periods were approximately 2,700 and $2,000 \mathrm{ft}^{3} / \mathrm{s}$, respectively. This represents approximately a 35 -percent decrease in flow. The sensitivity analysis was run by using the flow field from the June simulation with the August nutrient and temperature data.

A normalized sensitivity index $(S i j)$ was used to represent the percentage of change in the output variable (the mean DO concentration at site 9) resulting from a 1-percent change in the rate constant or input data (Brown and Barnwell, 1987). The normalized sensitivity index is:

$$
S_{i j}=\left(D Y_{j} / Y_{j}\right) /\left(D X_{i} / X_{i}\right),
$$

where

$S_{i j}$ is the normalized sensitivity index for output $Y_{j}$ to input $X_{i}$;

$D Y_{j}$ is the change in the output variable;

$Y_{j}$ is the original value of the output variable;

$D X_{i}$ is the change in the input variable; and

$X_{i}$ is the original value of the input variable.

The sensitivity analysis indicated that the simulated DO concentrations were most sensitive to the boundary concentration inputs of temperature and DO followed by sensitivity to change in streamflow. A 35-percent increase in streamflow resulted in a negative normalized sensitivity index for simulated DO concentrations, indicating a decrease in DO 
Table 16. Sensitivity indices for the Branched Lagrangian Transport Model inputs for site 9 on the Wateree River, S.C., August 12, 1997

[DO, dissolved oxygen; $\mathrm{mg} / \mathrm{L}$, milligram per liter]

\begin{tabular}{|c|c|c|c|c|}
\hline Model input & $\begin{array}{c}\text { Original } \\
\text { value }\end{array}$ & $\begin{array}{c}\text { Test } \\
\text { value }\end{array}$ & $\begin{array}{c}\text { Mean } \\
\text { simulated DO } \\
\text { August 12, } 1997 \\
(\mathrm{mg} / \mathrm{L})\end{array}$ & $\begin{array}{c}\text { Sensitivity } \\
\text { index }\end{array}$ \\
\hline Base value $^{\mathrm{a}}$ & & & 5.67 & \\
\hline \multicolumn{5}{|c|}{ Model input variables } \\
\hline A1 & 3.010 & 4.060 & 5.67 & 0.00 \\
\hline ALGSET & 0.070 & 0.100 & 5.67 & 0.00 \\
\hline ALPHA0 & 67.000 & 90.400 & 5.67 & 0.00 \\
\hline ALPHA1 & 0.090 & 0.122 & 5.67 & 0.00 \\
\hline ALPHA2 & 0.020 & 0.027 & 5.67 & 0.00 \\
\hline ALPHA3 & 1.400 & 1.890 & 5.70 & 0.02 \\
\hline ALPHA4 & 2.150 & 2.900 & 5.64 & -0.02 \\
\hline ALPHA5 & 3.430 & 4.630 & 5.55 & -0.06 \\
\hline ALPHA6 & 1.140 & 1.540 & 5.66 & -0.01 \\
\hline B1 & 1.130 & 1.530 & 5.67 & 0.00 \\
\hline BET1 & 1.000 & 1.350 & 5.60 & -0.04 \\
\hline BET2 & 0.600 & 0.810 & 5.66 & 0.00 \\
\hline BET3 & 0.200 & 0.270 & 5.66 & -0.01 \\
\hline CK1 & 0.160 & 0.216 & 5.56 & -0.06 \\
\hline CK4 & 18.600 & 25.110 & 5.64 & -0.02 \\
\hline CKL & 0.020 & 0.027 & 5.67 & 0.00 \\
\hline $\mathrm{CKN}$ & 0.260 & 0.351 & 5.66 & 0.00 \\
\hline CKP & 0.040 & 0.054 & 5.67 & 0.00 \\
\hline GRO & 2.500 & 3.380 & 5.71 & 0.02 \\
\hline PN & 0.250 & 0.340 & 5.67 & 0.00 \\
\hline RSPRT & 0.500 & 0.680 & 5.64 & -0.02 \\
\hline SHADO & 0.400 & 0.540 & 5.66 & 0.00 \\
\hline SHAD1 & 0.008 & 0.011 & 5.67 & 0.00 \\
\hline SIG3 & 10.000 & 13.500 & 5.64 & -0.01 \\
\hline SIG6 & 6.000 & 8.100 & 5.67 & 0.00 \\
\hline \multicolumn{5}{|c|}{ Meteorological inputs } \\
\hline Equilibrium temperature $^{b}$ & 1.000 & 1.350 & 5.51 & -0.08 \\
\hline Solar radiation $^{\mathrm{b}}$ & 1.000 & 1.350 & 5.67 & 0.00 \\
\hline Wind velocity ${ }^{\mathrm{b}}$ & 1.000 & 1.350 & 5.67 & 0.00 \\
\hline \multicolumn{5}{|c|}{ Constituent concentration inputs } \\
\hline Algal biomass ${ }^{b}$ & 1.000 & 1.350 & 5.66 & 0.00 \\
\hline Ammonia $^{\mathrm{b}}$ & 1.000 & 1.350 & 5.58 & -0.05 \\
\hline $\mathrm{CBODu}^{\mathrm{b}}$ & 1.000 & 1.350 & 5.55 & -0.06 \\
\hline Dissolved oxygen $^{\mathrm{b}}$ & 1.000 & 1.350 & 6.40 & 0.33 \\
\hline Dissolved phosphorus ${ }^{\mathrm{b}}$ & 1.000 & 1.350 & 5.67 & 0.00 \\
\hline Nitrate $^{b}$ & 1.000 & 1.350 & 5.67 & 0.00 \\
\hline Organic nitrogen ${ }^{\mathrm{b}}$ & 1.000 & 1.350 & 5.66 & -0.01 \\
\hline Organic phosphorus ${ }^{b}$ & 1.000 & 1.350 & 5.67 & 0.00 \\
\hline Temperature $^{\mathrm{b}}$ & 1.000 & 1.350 & 5.01 & -0.37 \\
\hline \multicolumn{5}{|c|}{ Using flow from June 1997 simulation (approximately 35 percent higher than August) } \\
\hline Flow & 1.000 & 1.350 & 5.30 & -0.20 \\
\hline
\end{tabular}

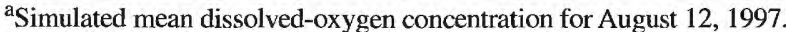

${ }^{\mathrm{b}}$ Time-dependent model input; original and test values are multiplicative factors. 
concentrations. The simulated DO concentrations showed no significant sensitivity to changes in any other model input variables (table 16).

\section{WATER-QUALITY MODEL APPLICATIONS}

The BLTM water-quality model of the Wateree River was used to simulate several hydrologic and water-quality scenarios to evaluate the effects on simulated DO concentrations. The results from these scenarios are intended to demonstrate the utility of the model in making water-resource management decisions and are not intended to be interpreted as a regulatory application of the model. The August 1997 validation data were used for the scenario simulations. Simulated model output was analyzed at seven waterquality sampling sites. The first scenario compares the 24-hour mean DO concentration for August 13, 1997, as simulated during the model validation, with simulations using two different streamflow patterns (fig. 45). The water-quality boundary conditions used in the validation model were applied with each streamflow pattern. The tributary flows were determined from the difference in the mean flows between USGS stations 02148000 and 02148315 . Each tributary inflow was included as a constant fraction of the total inflow based on percentage of intervening drainage area. Consequently, the differences in the simulated DO concentrations are a result of variations in streamflow.

The second scenario maintains the same streamflow used during the validation simulation but varies the loading from the effluent discharges. The water-quality boundary conditions for the river and tributaries were obtained by taking the 75 th-percentile nutrient data from the June and August 1997 samples. The boundary conditions for DO concentrations in the river and tributaries were set at the 25th-percentile concentration from the August 1997 data. The SCDHEC has used similar boundary conditions for DO and nutrient concentrations during wasteload allocation simulations on other rivers by using STORET data (W. Cantrell, South Carolina Department of Health and Environmental Control, oral commun., 1999).

The third scenario assumes that the effluent discharges are at the fully permitted National Pollutant Discharge Elimination System (NPDES) levels and evaluates the changes in DO concentrations by using the three streamflow periods from the first scenario. The boundary conditions for DO and other water- quality constituents in the river and tributaries were set to the same levels as those in the second scenario.

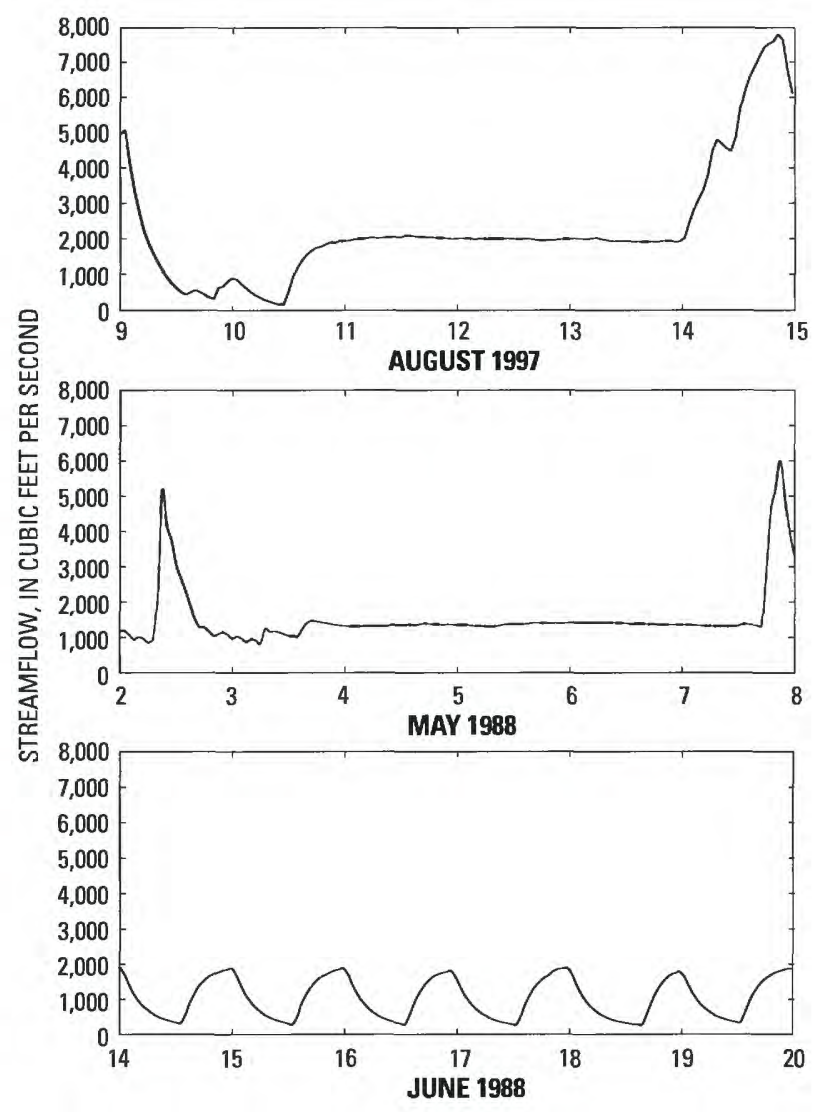

Figure 45. Boundary streamflow conditions at USGS station 02147930 that were used to compare the effects of changing flow patterns on the 24-hour mean dissolvedoxygen concentration from August 13, 1997, on the Wateree River, S.C.

\section{Variations in Streamflow}

A water-quality model can be used by waterresource managers to evaluate the effects of wastewater loads on DO, especially in determining the amount of wastewater that a receiving waterbody is able to assimilate. The capacity of a stream to assimilate oxygen-consuming substances is a function of many factors including streamflow, water temperature, reaeration, benthic oxygen demand, and channel geometry. Of particular concern, downstream from a hydroelectric plant, is the influence of variations in streamflow patterns. The USGS 
streamflow records at station 02148000 were reviewed from 1980 to 1997 to determine two periods with mean flows less than those used for the BLTM water-quality model validation (approximately $2,000 \mathrm{ft}^{3} / \mathrm{s}$ at station 02148000). One selected period, May 6, 1988, had a mean streamflow for the 24-hour averaging period of $1,400 \mathrm{ft}^{3} / \mathrm{s}$, and a second selected period, June 18 , 1988 , had a mean streamflow of $1,000 \mathrm{ft}^{3} / \mathrm{s}$ (fig. 45).

In a riverine system that is affected by pointsource effluents, it is typically assumed that as streamflow increases, DO concentrations also will increase and, conversely, decreasing the streamflow will result in decreasing DO concentrations. However, under the simulated conditions described above, the Wateree River model produced the opposite results. The simulation using streamflow from May 6, 1988, represented a decrease of 30 percent from the mean streamflow during the August 13,1997, simulation. This resulted in an increase in 24-hour mean DO concentrations ranging from 0.12 to $0.30 \mathrm{mg} / \mathrm{L}$. The simulation using streamflow from June 14-20, 1988, represented a decrease of 50 percent from the mean streamflow for the August 13, 1997, simulation. The decrease in streamflow resulted in an increase in 24hour mean DO concentrations ranging from 0.26 to $0.47 \mathrm{mg} / \mathrm{L}$ (fig. 46; table 17).
By using the output options in the BLTM, a budget can be produced showing the sources and sinks of DO for water parcels moving through the system. This was done at branch 1 grid 9 (RM 57.4), which was the location used for the streamflow and BLTM waterquality model sensitivity analyses, for the three flow periods used in the first scenario (figs. 47-49). Each figure consists of four graphs. The first graph shows the streamflow, mean depth, and mean velocity at the site. The second graph shows the DO at the current time step and the DO of the parcel when it first entered the branch. The third graph shows the changes in DO as a result of atmospheric reaeration. The fourth graph shows the changes in DO as a result of algal photosynthesis and respiration, decay of ultimate carbonaceous biochemical oxygen demand, and oxidation of ammonia. Consequently, at a particular time step, the DO changes shown in the third and fourth graphs could be added to the DO of the parcel when it entered the branch (from the second graph), and the result should be close to the DO at the current time step (also shown on the second graph). The changes in DO as a result of dispersion, oxidation to nitrate plus nitrite nitrogen, SOD, and mixing as a result of tributary inflow are not shown; however, their combined influence is relatively small.

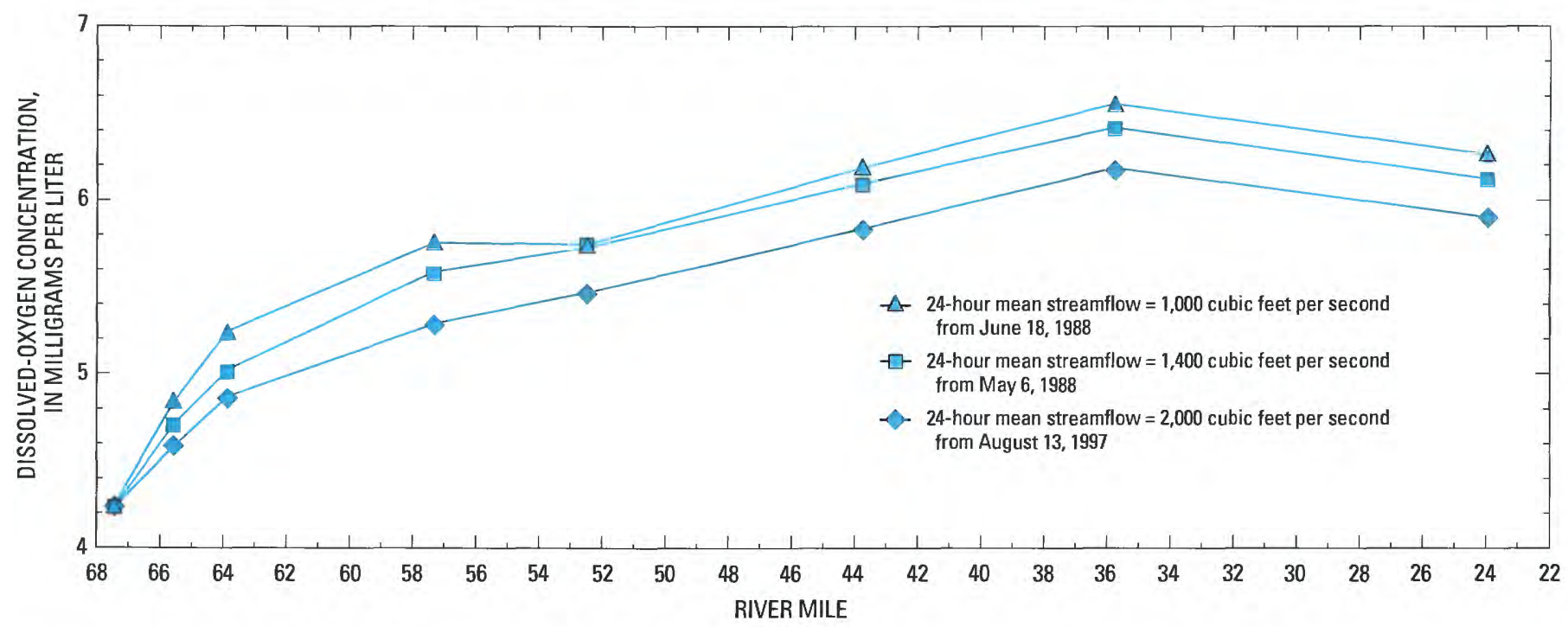

Figure 46. Longitudinal profiles of 24-hour mean dissolved-oxygen concentrations for three different streamflow periods on the Wateree River, S.C., using water-quality boundary data from August 13, 1997. 
Table 17. Simulated dissolved-oxygen concentrations (24-hour mean) for three streamflow conditions at eight sites on the Wateree River, S.C.

[ft ${ }^{3} / \mathrm{s}$, cubic foot per second: DO, dissolved-oxygen concentration; $\mathrm{mg} / \mathrm{L}$, milligram per liter]

\begin{tabular}{|c|c|c|c|c|c|c|}
\hline \multirow[b]{2}{*}{$\begin{array}{l}\text { Site no. } \\
\text { (fig. 9) }\end{array}$} & \multicolumn{2}{|c|}{$\begin{array}{c}\text { August 13, } 1997 \\
\text { (mean streamflow }=2,000 \mathrm{ft}^{3} / \mathrm{s} \text { ) }\end{array}$} & \multicolumn{2}{|c|}{$\begin{array}{c}\text { May 6, } 1988 \\
\text { (mean streamflow }=1,400 \mathrm{ft}^{3} / \mathrm{s} \text { ) }\end{array}$} & \multicolumn{2}{|c|}{$\begin{array}{c}\text { June } 18,1988 \\
\text { (mean streamflow }=1,000 \mathrm{ft}^{3} / \mathrm{s} \text { ) }\end{array}$} \\
\hline & River mile & $\begin{array}{l}\text { DO under } \\
\text { August } 13,1997, \\
\text { streamflow } \\
\text { conditions } \\
\text { (mg/L) }\end{array}$ & $\begin{array}{c}\text { DO } \\
(\mathrm{mg} / \mathrm{L})\end{array}$ & $\begin{array}{l}\text { DO change from } \\
\text { August } 13,1997, \\
\text { streamflow } \\
\text { conditions } \\
\text { (mg/L) }\end{array}$ & $\begin{array}{c}\text { DO } \\
(\mathrm{mg} / \mathrm{L})\end{array}$ & $\begin{array}{l}\text { DO change from } \\
\text { August } 13,1997 \\
\text { streamflow } \\
\text { conditions } \\
\text { (mg/L) }\end{array}$ \\
\hline $5^{\mathrm{a}}$ & 67.4 & 4.23 & 4.23 & 0.00 & 4.23 & 0.00 \\
\hline 6 & 65.6 & 4.58 & 4.70 & .12 & 4.84 & .26 \\
\hline 7 & 63.9 & 4.86 & 5.01 & .15 & 5.23 & .37 \\
\hline 8 & 57.3 & 5.28 & 5.58 & .30 & 5.75 & .47 \\
\hline 9 & 52.5 & 5.46 & 5.73 & .27 & 5.74 & .28 \\
\hline 10 & 43.8 & 5.83 & 6.09 & .26 & 6.18 & .35 \\
\hline 11 & 35.8 & 6.18 & 6.41 & .23 & 6.55 & .37 \\
\hline 12 & 23.8 & 5.90 & 6.12 & .22 & 6.26 & .36 \\
\hline
\end{tabular}

${ }^{\mathrm{a}}$ Water-quality boundary conditions unchanged.

As streamflow changes, atmospheric reaeration exerts the greatest influence on DO concentrations (figs. 47-49). Many of the reaeration algorithm options available in the QUAL2E subroutine are formulated as

$$
k_{2}=\left(C^{*} U^{x}\right) / H^{y},
$$

where

$k_{2}$ is the reaeration coefficient per day at 20 degrees Celsius;

$C$ is a constant;

$U$ is the velocity in feet per second; and

$H$ is the depth in feet.

The reaeration algorithm that was used in the Wateree River model calibration and validation was developed by Churchill and others (1962) and is formulated as

$$
k_{2}=\left(11.6 * U^{0.969}\right) / H^{1.673}
$$

Consequently, if the velocity remains approximately the same, as it does for these simulations, but the depth changes by a substantial amount, the reaeration coefficient can significantly change. As previously mentioned, the reaeration coefficients that were computed on the basis of field data from the August 1113,1997 , sampling period were within the range of those that were predicted by using the Churchill algorithm. As previously discussed, the samples collected during the June 23-25, 1997, reaeration study produced no detectable propane-gas concentrations. Consequently, the reaeration coefficients were unverifiable at a different streamflow. However, based on these simulations and the DO concentration budget analysis at site 9 , it can be concluded that the simulated DO concentrations are greatly influenced by atmospheric reaeration. In addition, this also explains why the normalized sensitivity analysis indicated that as flow decreased, DO concentrations increased. 

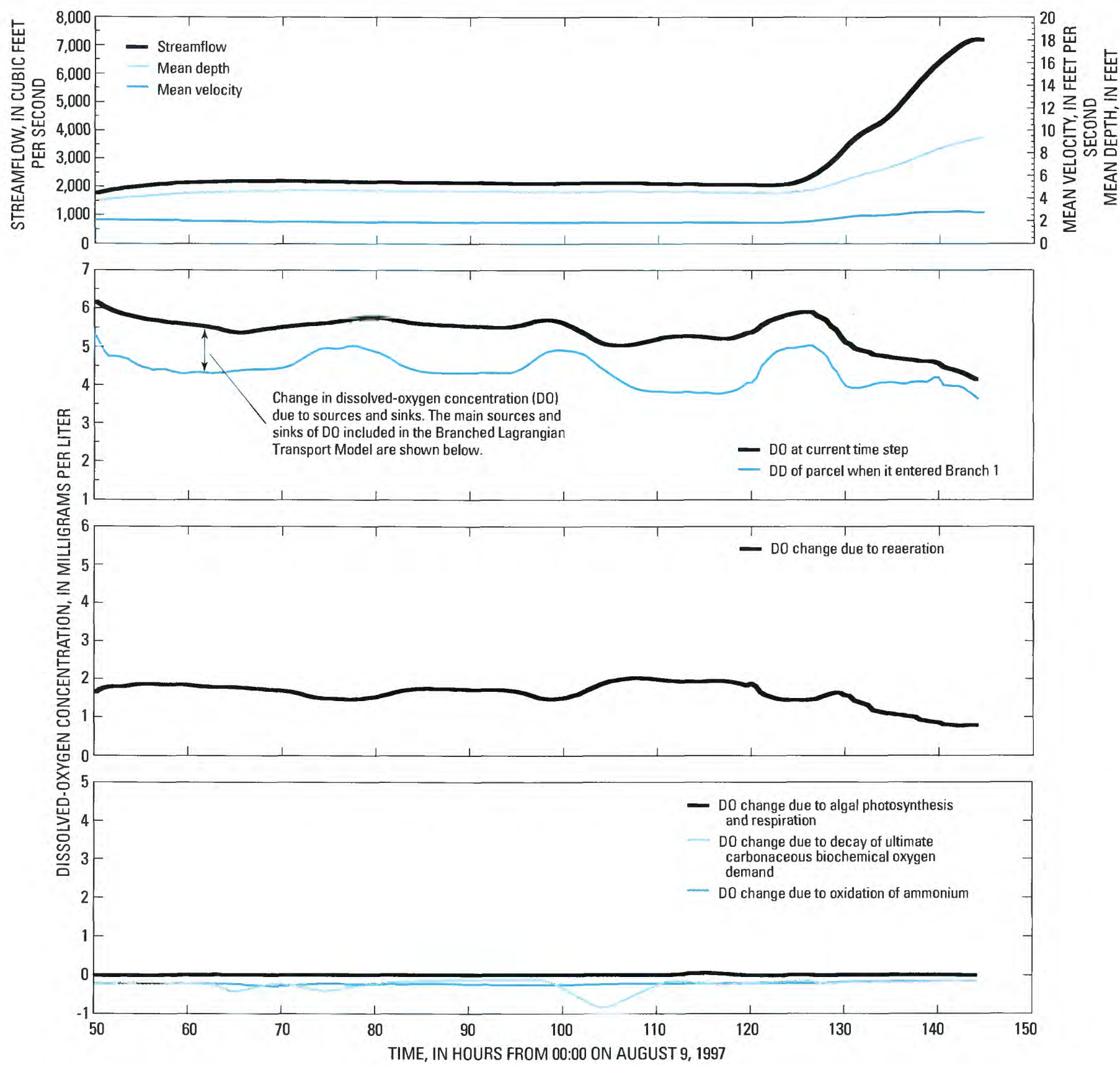

Figure 47. Simulated dissolved-oxygen (DO) concentration budget at branch 1 grid 9 (river mile 57.4) on the Wateree River, S.C., for the August 9-14, 1997, flow period. 

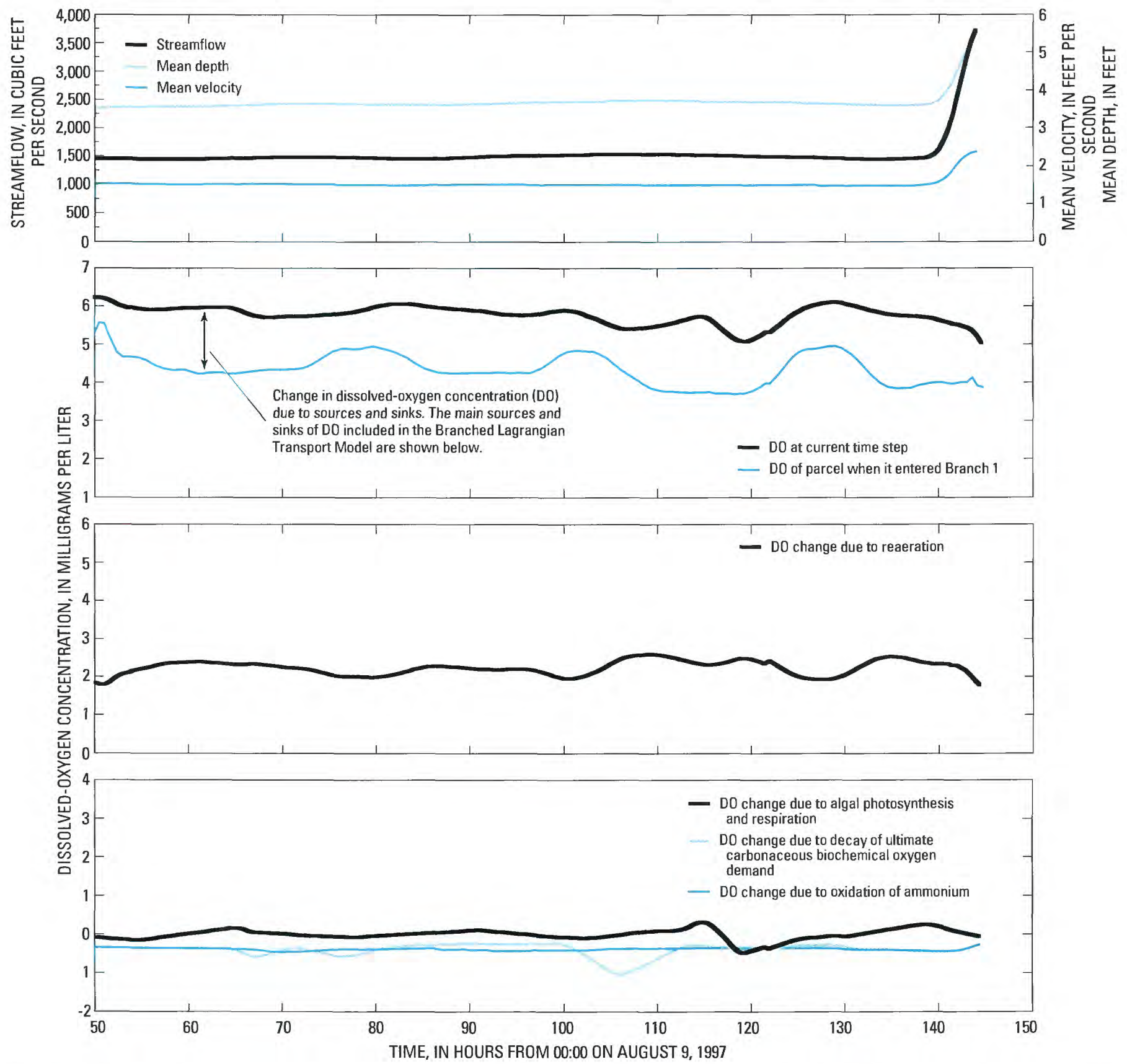

Figure 48. Simulated dissolved-oxygen (DO) concentration budget at branch 1 grid 9 (river mile 57.4) on the Wateree River, S.C., for August 9-14, 1997, using the May 2-7, 1988, flow period. 

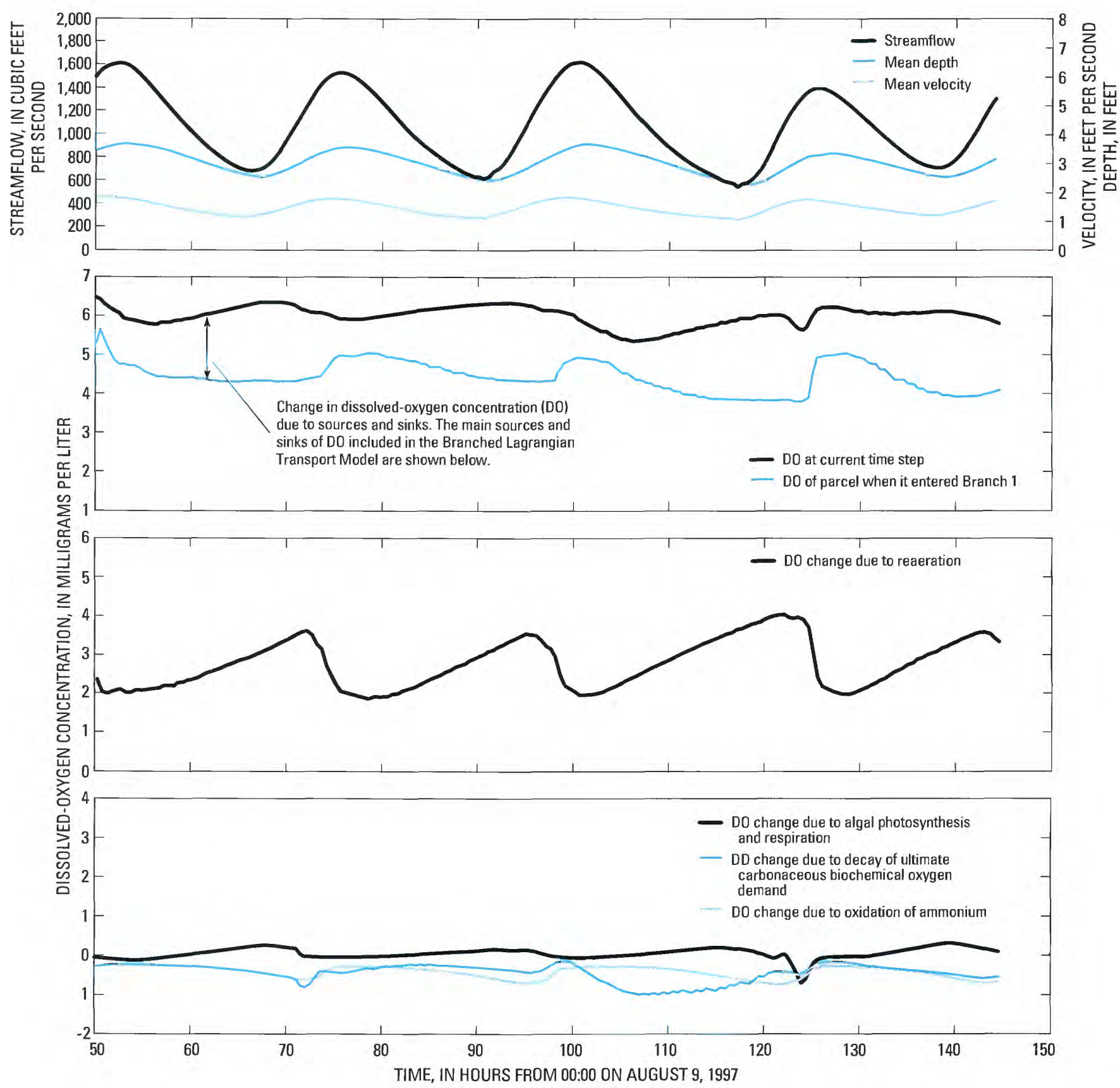

Figure 49. Simulated dissolved-oxygen (DO) concentration budget at branch 1 grid 9 (river mile 57.4) on the Wateree River, S.C., for August 9-14, 1997, using the June 14-19, 1988, flow period. 


\section{Variations in Discharge-Effluent Loading}

Wastewater effluent contains many oxygenconsuming constituents, primarily ammonia and biodegradable organic substances. In terms of waterresource management, the assimilative capacity of a waterbody is often expressed as pounds per day of UOD that can be assimilated without exceeding the State water-quality standard for DO concentrations. The UOD is the total, theoretical demand for oxygen from carbonaceous and nitrogenous sources. The SCDHEC defines the UOD by the equation (Conrads, 1998):

$$
\mathrm{UOD}=\left(\mathrm{BOD}_{5} \times F_{\text {ratio }}+\mathrm{NH}_{3}-\mathrm{N} \times 4.57\right)
$$$$
\times \text { Flow } \times 8.34 \text {, }
$$

\section{where}

UOD is the ultimate oxygen demand, in pounds per day;

$\mathrm{BOD}_{5}$ is the 5-day carbonaceous biochemical oxygen demand, in milligrams per liter;

$F_{\text {ratio }}$ is the conversion factor from $\mathrm{BOD}_{5}$ to ultimate carbonaceous biochemical oxygen demand, dimensionless;

$\mathrm{NH}_{3}-\mathrm{N}$ is the ammonia nitrogen concentration, in milligrams nitrogen per liter;

4.57 is the stoichiometric ratio of the milligrams of oxygen consumed per milligram of ammonia nitrogen oxidized, dimensionless;

Flow is wastewater flow, in million gallons per day; and

8.34 is the conversion factor to pounds per day.

The procedure for determining the assimilative capacity of an upland, unregulated stream is well established. The procedure involves a statistically computed steady-state, low-flow value, often referred to as the critical flow, that is used in conjunction with a critical water temperature in a simulation model. The results are interpreted according to the State waterquality standards. However, at least three significant issues pertain to the application of these procedures to the Wateree River. The first issue is how to determine critical flow on a regulated stream. The second issue is regulating an upland stream where DO concentrations periodically fall below the State water-quality standard under natural conditions. The third issue is answering the question of what is the natural condition for waters downstream of manmade impoundments. This study has documented the fact that DO concentrations in the Wateree River upstream from the effluent discharges sometimes do not meet the State standard. Resolving these issues is beyond the scope of this report.

However, defensible determination of the assimilative capacity will require that these issues be addressed.

For this report, various point-source loading conditions are compared with a condition where there are no point-source discharges into the system (a noload condition). The effects of the point-source loading then can be evaluated by comparing the differences in the DO concentrations for each simulation. The scenarios show how the model can be used to compare relative differences between various point-source loading conditions rather than to predict the absolute DO concentration of the system for a selected pointsource loading, hydrologic, and meteorologic condition. The modeled absolute value could be in error, but relative differences in the simulated results are more likely to be accurate.

Three simulations are compared by setting the loading from the effluent discharges to the level measured during the validation period (current condition), assuming no effluent discharges (no-load condition), and setting the effluent loads to their fully permitted conditions (fully loaded condition). As previously mentioned, a critical-flow condition has not been determined for the Wateree River. Consequently, the different loading scenarios were analyzed by using the simulated streamflow from the validation period. During the validation simulation, the mean UOD for the four dischargers was 4,170 pounds per day, or 39 percent of the permitted level $(10,730$ pounds per day). When compared to the no-load condition, the largest effect of the current-conditions loading is seen at site 10 , where the 24-hour minimum DO concentration decreased $0.09 \mathrm{mg} / \mathrm{L}$, and the 24-hour mean DO concentration decreased $0.08 \mathrm{mg} / \mathrm{L}$ (table 18; fig. 50). For the fully loaded conditions when compared to the no-load condition, the largest effect on DO concentrations also was seen at site 10 , where the 24-hour minimum concentration decreased $0.24 \mathrm{mg} / \mathrm{L}$, and the 24-hour mean concentration decreased $0.26 \mathrm{mg} / \mathrm{L}$. 
Table 18. Simulated dissolved-oxygen concentrations for two point-source loading conditions at eight locations on the Wateree River, S.C.

[DO, dissolved-oxygen concentration; $\mathrm{mg} / \mathrm{L}$, milligram per liter]

\begin{tabular}{|c|c|c|c|c|c|c|}
\hline \multirow[b]{2}{*}{$\begin{array}{l}\text { Site no. } \\
\text { (fig. 9) }\end{array}$} & \multirow[b]{2}{*}{ River mile } & \multirow[b]{2}{*}{$\begin{array}{l}\text { DO under } \\
\text { no-load } \\
\text { condition } \\
\text { (mg/L) }\end{array}$} & \multicolumn{2}{|c|}{$\begin{array}{l}\text { Actual conditions } \\
\text { (August 13, 1997) }\end{array}$} & \multicolumn{2}{|c|}{$\begin{array}{l}\text { Fully permitted } \\
\text { conditions }\end{array}$} \\
\hline & & & $\begin{array}{c}\mathrm{DO} \\
(\mathrm{mg} / \mathrm{L})\end{array}$ & $\begin{array}{l}\text { DO change } \\
\text { from } \\
\text { no-load } \\
\text { condition } \\
\text { (mg/L) }\end{array}$ & $\underset{\text { (mg/L) }}{\mathrm{DO}}$ & $\begin{array}{l}\text { DO change } \\
\text { from } \\
\text { no-load } \\
\text { condition } \\
\text { (mg/L) }\end{array}$ \\
\hline \multicolumn{7}{|c|}{ August 13, 1997, 24 -hour minimum } \\
\hline $5^{\mathrm{a}}$ & 67.4 & 3.78 & 3.78 & 0.00 & 3.78 & 0.00 \\
\hline 6 & 65.6 & 4.08 & 4.13 & .05 & 4.12 & .04 \\
\hline 7 & 63.9 & 4.40 & 4.44 & .04 & 4.35 & -.05 \\
\hline 8 & 57.3 & 4.93 & 4.92 & -.01 & 4.78 & -.15 \\
\hline 9 & 52.5 & 4.94 & 4.89 & -.05 & 4.71 & -.23 \\
\hline 10 & 43.8 & 5.15 & 5.06 & -.09 & 4.91 & -.24 \\
\hline 11 & 35.8 & 5.61 & 5.56 & -.05 & 5.41 & -.20 \\
\hline 12 & 23.8 & 5.35 & 5.27 & -.08 & 5.13 & -.22 \\
\hline \multicolumn{7}{|c|}{ August $13,1997,24$-hour mean } \\
\hline 5 & 67.4 & 3.78 & 3.78 & 0.00 & 3.78 & 0.00 \\
\hline 6 & 65.6 & 4.13 & 4.14 & .01 & 4.14 & .01 \\
\hline 7 & 63.9 & 4.41 & 4.46 & .05 & 4.41 & .00 \\
\hline 8 & 57.3 & 5.01 & 4.99 & -.02 & 4.88 & -.13 \\
\hline 9 & 52.5 & 5.09 & 5.07 & -.02 & 4.89 & -.20 \\
\hline 10 & 43.8 & 5.27 & 5.19 & -.08 & 5.01 & -.26 \\
\hline 11 & 35.8 & 5.73 & 5.69 & -.04 & 5.54 & -.19 \\
\hline 12 & 23.8 & 5.56 & 5.50 & -.06 & 5.36 & -.20 \\
\hline
\end{tabular}

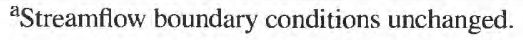

\section{Variations in Discharge-Effluent Loading and Streamflow}

A third scenario simulation was run combining the changes in streamflow with the changes in pointsource loadings. As in the previous simulation, the effluent loads were set to the current (1999) NPDES permit limits (total $\mathrm{UOD}=10,730$ pounds). The three streamflow patterns that were used in the previous flowpattern scenarios were assumed. When compared to the fully loaded condition using the streamflow from the validation period (August 13, 1997), reducing the flow by 35 percent caused an increase in 24 -hour mean DO concentrations from $0.03 \mathrm{mg} / \mathrm{L}$ at site 9 to $0.15 \mathrm{mg} / \mathrm{L}$ at site 10 (table 19; fig. 51). Using the streamflow from June 18,1988 , which is a 48-percent reduction in streamflow from August 13, 1997, the change in the 24-hour mean DO concentrations increased from $0.19 \mathrm{mg} / \mathrm{L}$ at site 12 to $0.59 \mathrm{mg} / \mathrm{L}$ at site 11. Once again, the influence of atmospheric reaeration as the flows were reduced resulted in increased 24-hour mean dissolved-oxygen concentrations. It could be assumed that a continual reduction in streamflow would eventually reach a point of diminishing returns, and the modeled DO concentrations would begin to decrease. 

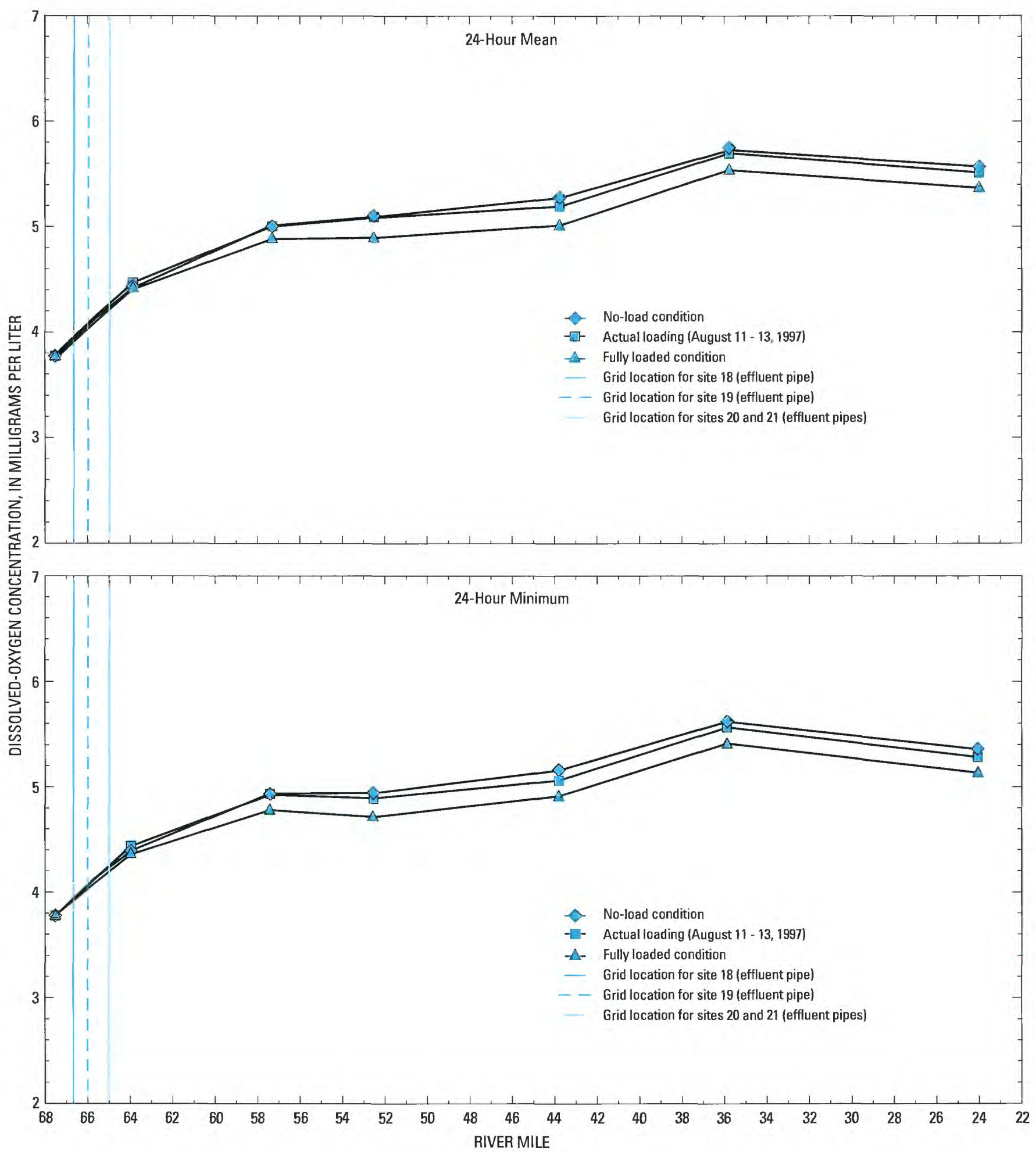

Figure 50. Longitudinal profiles of 24-hour mean and minimum dissolved-oxygen concentration differences between the noload condition and two point-source loading conditions at eight locations on the Wateree River, S.C., August 13, 1997. 
Table 19. Simulated dissolved-oxygen concentrations (24-hour mean) for three streamflow conditions assuming fully permitted effluent loads at eight locations on the Wateree River, S.C.

[ $\mathrm{ft}^{3} / \mathrm{s}$, cubic foot per second; DO, dissolved-oxygen concentration: $\mathrm{mg} / \mathrm{L}$, milligram per liter]

\begin{tabular}{|c|c|c|c|c|c|c|}
\hline \multirow[b]{2}{*}{$\begin{array}{l}\text { Site no. } \\
\text { (fig. 9) }\end{array}$} & \multicolumn{2}{|c|}{$\begin{array}{c}\text { August } 13,1997 \\
\text { (mean streamflow }=2,000 \mathrm{ft}^{3} / \mathrm{s} \text { ) }\end{array}$} & \multicolumn{2}{|c|}{$\begin{array}{c}\text { May 6, } 1988 \\
\left.\text { (mean streamflow }=1,400 \mathrm{ft}^{3} / \mathrm{s}\right)\end{array}$} & \multicolumn{2}{|c|}{$\begin{array}{c}\text { June } 18,1988 \\
\text { (mean streamflow }=1,000 \mathrm{ft}^{3} / \mathrm{s} \text { ) }\end{array}$} \\
\hline & River mile & $\begin{array}{c}\text { DO under } \\
\text { August 13, 1997, } \\
\text { streamflow } \\
\text { conditions } \\
\text { (mg/L) }\end{array}$ & $\begin{array}{c}\mathrm{DO} \\
(\mathrm{mg} / \mathrm{L})\end{array}$ & $\begin{array}{l}\text { DO change from } \\
\text { August } 13,1997, \\
\text { streamflow } \\
\text { conditions } \\
\text { (mg/L) }\end{array}$ & $\begin{array}{c}\mathrm{DO} \\
(\mathrm{mg} / \mathrm{L})\end{array}$ & $\begin{array}{c}\text { DO change from } \\
\text { August 13, 1997, } \\
\text { streamflow } \\
\text { conditions } \\
\text { (mg/L) }\end{array}$ \\
\hline 5 & 67.4 & 3.78 & 3.78 & 0.00 & 3.78 & 0.00 \\
\hline 6 & 65.6 & 4.13 & 4.25 & .12 & 4.36 & .23 \\
\hline 7 & 63.9 & 4.41 & 4.51 & .10 & 4.74 & .33 \\
\hline 8 & 57.3 & 4.88 & 5.02 & .14 & 5.36 & .48 \\
\hline 9 & 52.5 & 4.89 & 4.92 & .03 & 5.20 & .31 \\
\hline 10 & 43.8 & 5.01 & 5.16 & .15 & 5.46 & .45 \\
\hline 11 & 35.8 & 5.54 & 5.61 & .07 & 6.13 & .59 \\
\hline 12 & 23.8 & 5.36 & 5.31 & .05 & 5.65 & .19 \\
\hline
\end{tabular}

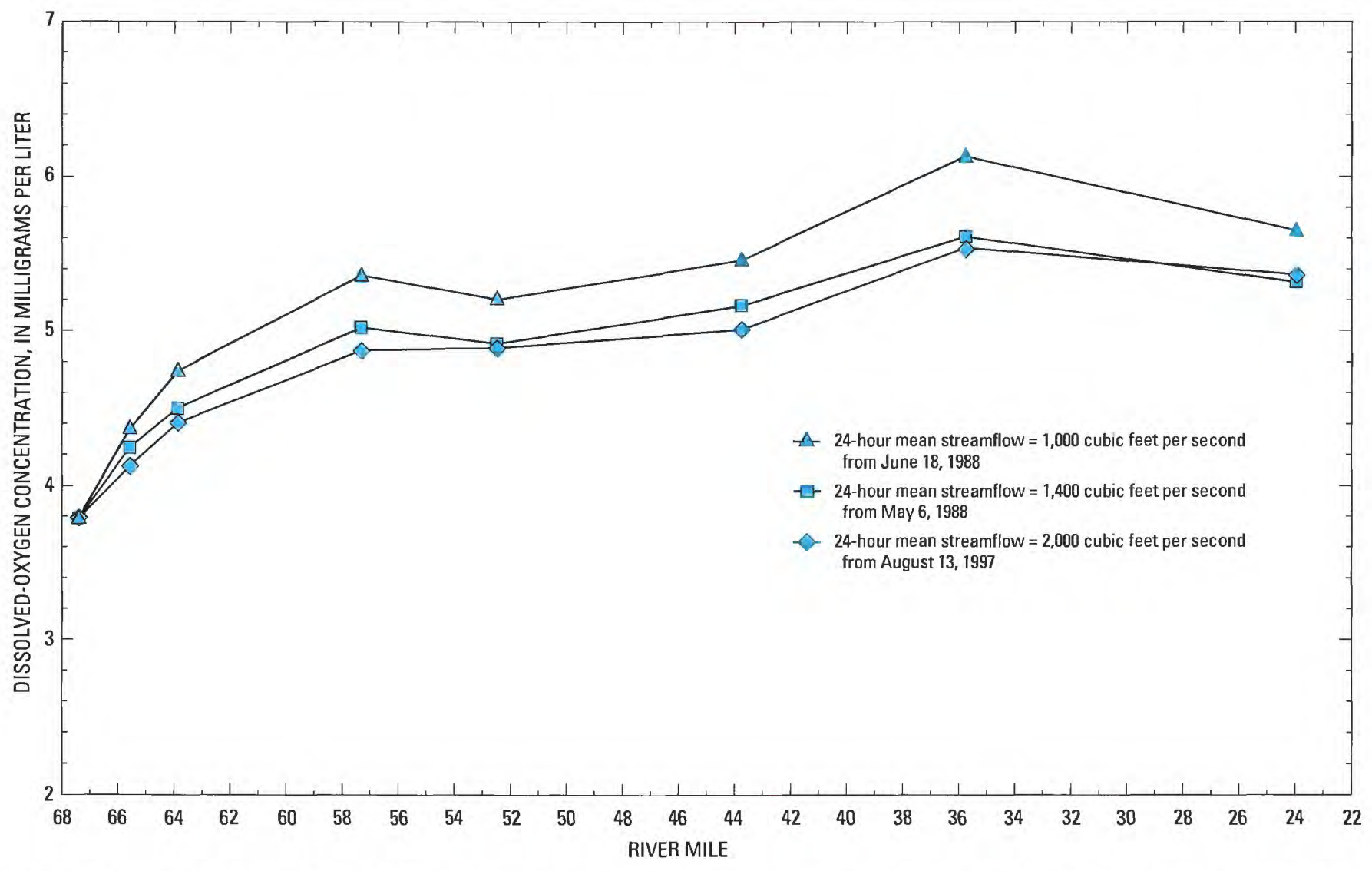

Figure 51. Longitudinal profiles of 24-hour mean dissolved-oxygen concentrations for three streamflow periods assuming fully permitted effluent loads at eight locations on the Wateree River, S.C. 


\section{SUMMARY}

Historical and recent streamflow and waterquality data were reviewed and analyzed to characterize the water quality in the Wateree River, South Carolina. Water-quality data from the South Carolina Department of Health and Environmental Control monitoring stations were analyzed for statistical trends. Analysis of data collected from 1980 to 1995 revealed decreasing trends in ammonia nitrogen at all stations where data were available and decreasing trends in 5-day biochemical oxygen demand at three river stations. Long-term streamflow and water-quality data collected at two U.S. Geological Survey stations also were analyzed for statistical trends. Results suggested that the correlation between streamflow and dissolved-oxygen concentrations in the Wateree River was negligible. A strong negative correlation $\left(r^{2}\right.$ greater than or equal to 0.86 ) exists between dissolved-oxygen concentrations and water temperature. Analysis of water-quality data collected at USGS station 02148000 , located in the upper reach of the Wateree River, indicated that during water years 1992-97, dissolved-oxygen concentrations were lower than the minimum and mean standards as defined by the South Carolina Department of Health and Environmental Control 15 and 19 percent of the time, respectively. In addition, during water years 1970-97 at USGS station 02148315, located at the downstream study limit, dissolved-oxygen concentrations were lower than the minimum and mean standards 0.3 and 2.4 percent of the time, respectively.

Longitudinal profiling of dissolved-oxygen concentrations during the spring and summer of 1996 revealed a decrease in dissolved-oxygen concentrations that occurred upstream from the point-source discharges. For the profiles made from May to September 1996, the mean dissolved-oxygen concentration decrease upstream from the effluent discharges was $2.0 \mathrm{mg} / \mathrm{L}$, and the decrease downstream from the effluent discharges was $0.2 \mathrm{mg} / \mathrm{L}$. Several theories were investigated to understand the dissolvedoxygen dynamics in the upper Wateree River. From these investigations and from data collected during synoptic water-quality sampling during June and August 1997, it was concluded that the dissolvedoxygen concentration decrease is associated with high concentrations of reduced substances in the low dissolved-oxygen concentration water at the lower elevations of the lake; the reduced substances are being oxidized rapidly in the upper reach of the Wateree River. In a shoal area just below the dam, the reaeration rate exceeded the oxidation rate, and dissolved-oxygen concentrations increased. Once the water flowed out of the shoal area, the oxidation rate exceeded the reaeration rate, and the dissolved-oxygen concentrations decreased. The oxidation rate then decreased as the reactions were satisfied, and the dissolved-oxygen concentrations once again increased. Further investigations are needed to better understand and define the water quality in the upper Wateree River.

The USGS one-dimensional dynamic flow BRANCH model and the Branched Lagrangian Transport Model (BLTM) were calibrated and validated for the Wateree River. The transport model begins approximately 0.9 mi upstream from U.S. 1 and ends just downstream from U.S. 378, covering a 43.5-mi reach of the river. The BRANCH model extends from approximately 0.9 mi upstream from U.S. 1 to USGS station 02148315, Wateree River at Eastover, S.C., covering a 57.3-mi reach of the river. Data collected during two synoptic water-quality sampling periods, June 21-23 and August 11-13, 1997, were used to calibrate and validate the BLTM, respectively. Data included dye-tracer concentrations collected at six locations, and concentrations of nutrients and metals, biochemical oxygen demand, and dissolved oxygen, and measurements of water temperature collected at nine locations.

A sensitivity analysis of the simulated dissolvedoxygen concentrations to model coefficients and data inputs indicated the simulated dissolved-oxygen concentrations were most sensitive to changes in the boundary concentration inputs of water temperature and dissolved oxygen followed by sensitivity to change in streamflow. The simulated dissolved-oxygen concentrations showed no significant sensitivity to changes in model input rate kinetics.

The BLTM water-quality model of the Wateree River was used to simulate three hydrologic conditions to assess the effects of flow on dissolved-oxygen concentrations. The changes in dissolved-oxygen concentrations caused by changing streamflow conditions were evaluated on the basis of the longitudinal profiles of 24-hour mean dissolved-oxygen concentrations at seven locations. The water-quality parameters from August 13, 1997, were held constant, while the streamflow was varied. On August 13, 1997, the mean streamflow was $2,000 \mathrm{ft}^{3} / \mathrm{s}$. Dissolvedoxygen concentrations were simulated for mean 
streamflows of 1,000 and $1,400 \mathrm{ft}^{3} / \mathrm{s}$. When compared with mean streamflow of $2,000 \mathrm{ft}^{3} / \mathrm{s}$ on August 13 , 1997, the simulations using mean streamflows of 1,000 and $1,400 \mathrm{ft}^{3} / \mathrm{s}$ resulted in an increase in 24-hour mean dissolved-oxygen concentrations ranging from 0.26 to $0.47 \mathrm{mg} / \mathrm{L}$ and from 0.12 and $0.30 \mathrm{mg} / \mathrm{L}$, respectively. A dissolved-oxygen budget was computed at branch 1 grid 9 (river mile 57.4) for the three simulations. The results indicated that the increase in simulated dissolved-oxygen concentrations was a result of increased simulated atmospheric reaeration, which, in turn, was the result of the changing hydraulic conditions at the different flows.

Different point-source loading conditions to the system were evaluated. From comparisons with the noload conditions, the August 1997 validation period conditions changed the 24-hour minimum and mean dissolved-oxygen concentration of August 13, 1997, by a range of -0.08 to $0.05 \mathrm{mg} / \mathrm{L}$. Setting all point-source loadings to the fully permitted ultimate oxygen demand loading changed the 24-hour minimum and mean dissolved-oxygen concentration by a range of -0.26 to $0.01 \mathrm{mg} / \mathrm{L}$.

All the point-source loadings were set to the current (1999) fully permitted ultimate oxygen demand levels, and dissolved-oxygen concentrations were simulated under three different streamflow conditions. Changes in 24-hour mean dissolved-oxygen concentrations using the August 1997 validation streamflow conditions, which had a mean streamflow of $2,000 \mathrm{ft}^{3} / \mathrm{s}$, were compared with simulations using mean streamflows 1,000 and $1,400 \mathrm{ft}^{3} / \mathrm{s}$. The results indicated increases in the 24-hour mean dissolvedoxygen concentrations ranging from 0.19 to $0.59 \mathrm{mg} / \mathrm{L}$ and from 0.03 to $0.15 \mathrm{mg} / \mathrm{L}$, respectively. The influence of the atmospheric reaeration as the flows were reduced resulted in increased 24-hour mean dissolved-oxygen concentrations.

\section{SELECTED REFERENCES}

Borders, T., 1984, Water-quality model of the Wateree River. Kershaw County, South Carolina: South Carolina Department of Health and Environmental Control, Technical Report No. 021-84, 64 p.
Bowie, B.L., Mills, W.B., Porcella, D.B., Campbell, C.L., Pagenkopf, J.R., Rupp, G.L., Johnson, K.M., Chan, P.W.H., Gherini, S.A., and Chamberlin, C.E., 1985, Rates, constants, and kinetics formulation in surface water quality modeling ( $2 \mathrm{~d}$ ed.): U.S. Environmental Protection Agency, EPA/600/3-85/040, 55 p.

Brown, L.C., and Barnwell, T.O., Jr., 1987, The enhanced stream water quality models QUAL2E and QUAL2EUNCAS-Documentation and user manual: Athens, Ga., U.S. Environmental Protection Agency, Environmental Research Laboratory, EPA/600/3-87/007, $189 \mathrm{p}$.

Churchill, M.A., Elmore, H.L., and Buckingham, R.A., 1962, The prediction of stream reaeration rates: ASCE Journal Sanitary Engineering Division, v. 88, SA4, p. 1-46.

Conrads, P.A., 1998, Simulation of temperature, nutrients, biochemical oxygen demand, and dissolved oxygen in the Ashley River near Charleston, South Carolina: U.S. Geological Survey Water-Resources Investigations Report 98-4150, $56 \mathrm{p}$.

Conrads, P.A., and Smith, P.A., 1997, Simulation of temperature, nutrients, biochemical oxygen demand, and dissolved oxygen in the Cooper and Wando Rivers near Charleston, South Carolina, 1992-95: U.S. Geological Survey Water-Resources Investigations Report 97-4151, $58 \mathrm{p}$.

Cooke, C.W., 1936, Geology of the Coastal Plain of South Carolina: U.S. Geological Survey Bulletin 867, 196 p.

Dortch, M.S., Tillman, D.H., and Bunch, B.W., 1992, Modeling water quality of reservoir tailwaters: Vicksburg, Miss., U.S. Army Engineer Waterways Experiment Station, Technical Report W-92-1, 73 p. + app.

Feaster, T.D., 1998, Utilizing a Lagrangian-Eulerian approach to water-quality assessment of the Wateree River, S.C.: First Federal Interagency Hydrologic Modeling Conference, Las Vegas, Nev., 1998, v. 1, p. $41-47$.

Godfrey, R.K., and Wooten, J.W., 1979, Aquatic and wetland plants of Southeastern United States: Athens, Ga., The University of Georgia Press, 712 p.

Hurley Jr., N.M., 1991, Transport simulation of striped bass eggs in the Congaree, Wateree, and Santee Rivers, South Carolina: U.S. Geological Survey WaterResources Investigations Report 91-4088, 57 p.

Jobson, H.E., 1977, Thermal model for evaporation from open channels: Baden, Germany, 17th Congress of the International Association for Hydraulic Research Proceedings, v. 2, p. 95-102. 
1980, Comment on "A new collocation method for the solution of the convection-dominated transport equation," by Pinder, G.E., and Shapiro, Allen, 1979, in Water Resources Research, v. 15, no. 5, p. 1177-1182: Water Resources Research, v. 16, no. 6 , p. 1135-1136.

1981, Temperature and the solute-transport simulation in streamflow using a Lagrangian reference frame: U.S. Geological Survey Water-Resources Investigations Report 81-2, $165 \mathrm{p}$.

1989, Users manual for an open-channel streamflow model based on the diffusion analogy: U.S. Geological Survey Water-Resources Investigations Report 894133, $73 \mathrm{p}$.

1997, Enhancements to the Branched Lagrangian Transport Modeling System: U.S. Geological Survey Water-Resources Investigations Report 97-4050, $56 \mathrm{p}$.

Jobson, H.E., and Schoelhamer, D.H., 1987, User manual for a Branched Lagrangian Transport Model: U.S. Geological Survey Water-Resources Investigations Report 87-4163, 73 p.

Kilpatrick, F.A., Rathbun, R.E., Yotsukura, N., Parker, G.W., and Delong, L.L., 1989, Determination of stream reaeration coefficients by use of tracers: U.S. Geological Survey Techniques of Water-Resources Investigations, book 3 , chap. A18, $52 \mathrm{p}$.

Nix, J., Hamlin-Tillman, D.E., Ashby, S.L., and Dortch, M.S., 1991, Water quality of selected tailwaters: Vicksburg, Miss., U.S. Army Engineer Waterways Experiment Station, Technical Report W-91-2, 54 p. + app.

O'Conner, D.J., and Dobbins, W.E., 1958, Mechanism of reaeration in natural streams: American Society of Civil Engineer Transaction Paper No. 2934, p. 641-684.

Ott, R.L., 1993, An introduction to statistical methods and data analysis (4th ed.): Belmont, Calif., Wadsworth Publishing Co., 1,051 p. + app.

Owens, M., Edwards, R.W., and Gibbs, J.W., 1964, Some reaeration studies in streams: International Journal of Air and Water Pollution, v. 8, p. 469-486.

Raschke, R.L., 1994, Phytoplankton bloom frequencies in a population of small southeastern impoundments: Lake and Reservoir Management, v. 8, p. 205-210.

Regan, R.S., and Schaffranek, R.W., 1985, A computer program for analyzing channel geometry: U.S. Geological Survey Water-Resources Investigations Report 85-4335, 49 p.

Schaffranek, R.W., Baltzer, R.A., and Goldberg, D.C., 1981, A model for simulation of flow in singular and interconnected channels: U.S. Geological Survey Techniques of Water-Resources Investigations book 7 , chap. C3, $110 \mathrm{p}$.
Smith, G.D., 1985, Numerical solution of partial differential equations, finite difference methods ( $3 \mathrm{~d}$ ed.): London, England, Brunel University, p. 43-45.

South Carolina Department of Health and Environmental Control, 1993, Water classifications and standards (Reg. 61-68) and classified waters (Reg. 61-69) for the State of South Carolina: South Carolina Department of Health and Environmental Control, $36 \mathrm{p}$.

1996a, Lake Wateree diagnostic study: Columbia, S.C., South Carolina Department of Health and Environmental Control, Bureau of Water, Technical Report No. 001-96, 39 p. + app.

1996b, Watershed water quality management strategy, Catawba-Santee Basin: Columbia, S.C., South Carolina Department of Health and Environmental Control, Bureau of Water, Technical Report No. 002-96, 192 p. + app.

South Carolina Water Resources Commission, 1983, South Carolina State water assessment: SCWRC Report No. $140,367 \mathrm{p}$.

Thomann, R.V., and Fitzpatrick, J.J., 1982, Calibration and verification of a mathematical model of the eutrophication of the Potomac Estuary: Prepared for the District of Columbia Department of Environmental Services.

Thompson, D.B., 1992, Numerical methods 101convergence of numerical models, in Jennings, M., and Bhowmik, N.G., eds., Hydraulic engineeringsaving a threatened resource-in search of solutions: New York, American Society of Civil Engineers, p. 398-403.

Thomson, N.R., Sykes, J.F., and Lennox, W.C., 1984, A Lagrangian porous media mass transport model: Water Resources Research, v. 20, no. 3, p. 391-403.

Tufford, D.L., Flora, J.R., McKellar, H.N., and Meadows, M.E., 1997, Water quality model and monitoring needs assessment for Lake Wateree, S.C.: Columbia, S.C., Department of Environmental Health Sciences and Department of Civil and Environmental Engineering, University of South Carolina, Final report submitted to Lake Wateree Homeowners Association, 86 p.

U.S. Geological Survey, 1953a, Camden South, S.C., quadrangle: U.S. Geological Survey 7.5-minute series topographic map, scale 1:24,000.

1953b, Eastover, S.C., quadrangle: U.S. Geological Survey 7.5-minute series topographic map, scale $1: 24,000$.

1953c, Leesburg, S.C., quadrangle: U.S. Geological Survey 7.5-minute series topographic map, scale 1:24,000.

1953d, Lugoff, S.C., quadrangle: U.S. Geological Survey 7.5-minute series topographic map, scale $1: 24,000$. 
1953e, Poinsett State Park, S.C., quadrangle: U.S. Geological Survey 7.5-minute series topographic map, scale 1:24,000.

1953f, Rembert, S.C., quadrangle: U.S. Geological Survey 7.5-minute series topographic map, scale $1: 24,000$.

1953g, Wateree, S.C., quadrangle: U.S. Geological Survey 7.5-minute series topographic map, scale $1: 24,000$. 1953h, Wedgefield, S.C., quadrangle: U.S.

Geological Survey 7.5-minute series topographic map, scale 1:24,000.

1988, Rabon Crossroads, S.C., quadrangle: U.S.

Geological Survey 7.5-minute series topographic map, scale 1:24,000.

Wang, Wuncheng, 1979, Fractionation of sediment oxygen demand: Water Research, v. 14, p. 603-612. 


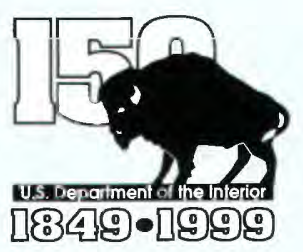

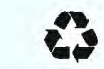

